\title{
Selectivity and Physicochemical Optimization of Repurposed Pyrazolo[1,5-b]pyridazines for the Treatment of Human African Trypanosomiasis
}

Westley F. Tear, ${ }^{\dagger}$ Seema Bag, ${ }^{\dagger}$ Rosario Diaz-Gonzalez, ${ }^{\dagger}$ Gloria Ceballos-Pérez, Domingo I. Rojas-Barros, ${ }^{\ddagger}$ Carlos Cordon-Obras, ${ }^{\ddagger} \perp$ Guiomar Pérez-Moreno, Raquel García-Hernández, ${ }^{\ddagger}$ Maria Santos Martinez-Martinez, ${ }^{\S}$ Luis Miguel Ruiz-Perez, Francisco Gamarro, ${ }^{\ddagger}$ Dolores Gonzalez Pacanowska, ${ }^{\ddagger}$ Conor R. Caffrey, ${ }^{\prime \prime}$ Lori Ferrins, ${ }^{\dagger}$ Pilar Manzano, ${ }^{\S}$ Miguel Navarro, ${ }^{\ddagger}$ and Michael P. Pollastri* ${ }^{\dagger} \dagger$

${ }^{\dagger}$ Department of Chemistry \& Chemical Biology, Northeastern University, 360 Huntington Avenue, Boston, Massachusetts 02115 , United States

"Instituto de Parasitología y Biomedicina “López-Neyra”, Consejo Superior de Investigaciones Cientificas (CSIC), Granada 18016, Spain

${ }^{\S}$ Tres Cantos Medicines Development Campus, DDW and CIB, GlaxoSmithKline, Tres Cantos 28760, Spain

"Center for Discovery and Innovation in Parasitic Diseases, Skaggs School of Pharmacy and Pharmaceutical Sciences, University of California San Diego, 9500 Gilman Drive, La Jolla, California 92093, United States

Supporting Information

ABSTRACT: From a high-throughput screen of 42444 known human kinases inhibitors, a pyrazolo[1,5-b]pyridazine scaffold was identified to begin optimization for the treatment of human African trypanosomiasis. Previously reported data for analogous compounds against human kinases GSK- $3 \beta$, CDK-2, and CDK-4 were leveraged to try to improve the selectivity of the series, resulting in 23a which showed selectivity for T. $b$. brucei over these three human enzymes. In parallel, properties known to influence the absorption, distribution, metabolism, and excretion (ADME) profile of the series were optimized resulting in $20 \mathrm{~g}$ being progressed into an efficacy study in mice. Though $\mathbf{2 0 g}$ showed toxicity in mice, it also demonstrated CNS penetration in a PK study and significant reduction of parasitemia in four out of the six mice.

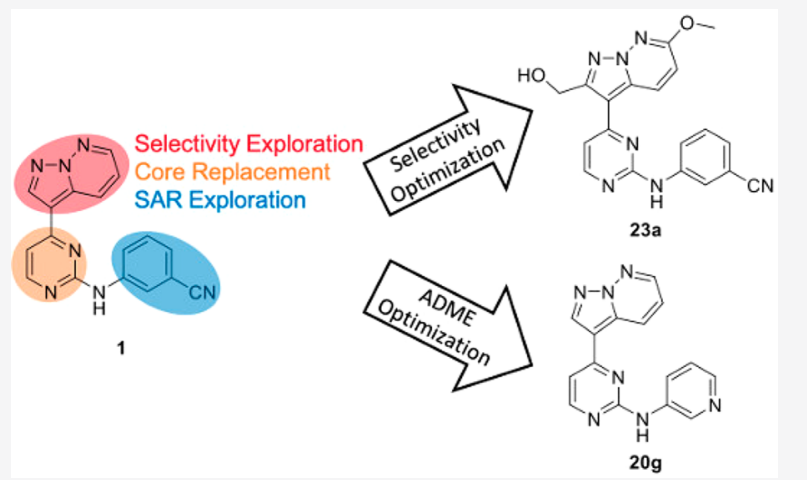

\section{INTRODUCTION}

Human African trypanosomiasis (HAT), or sleeping sickness as it is commonly referred to, is a parasitic disease caused by two subspecies of Trypanosoma brucei. ${ }^{1}$ Despite sharing a life cycle and causing similar symptoms in patients, these two subspecies progress at vastly different rates. T. $b$. gambiense is more common (98\% of cases), and infection takes an average of 3 years to run its course (ending in fatality), while T. $b$. rhodesiense is more virulent and infections can cause death within weeks to months of infection. ${ }^{2-4}$ There were 1446 documented cases of HAT in 2017, with an estimated 13 million people living in areas of moderate to high risk of infection. ${ }^{1,2}$ Fatal if left untreated, HAT has two stages; in the first stage T. brucei resides and multiplies in the blood and lymphatic systems. Infections often are not diagnosed due to nondescript symptoms, commonly associated with the flu. ${ }^{1,3}$ In the second stage, the parasite crosses the blood-brain barrier $(\mathrm{BBB})$ to infect the central nervous system (CNS), and those infected present more readily diagnosable symptoms such as disruptions to sleeping patterns and cognitive dysfunction and can become comatose.

There are currently two approved therapies for stage 1 HAT, pentamidine for T. b. gambiense infections and suramin for T. $b$. rhodesiense infections; both are ineffective against stage 2 of the disease. $^{2}$

In the past, the two principal treatments for stage 2 of the disease were eflornithine for T. $b$. gambiense and melarsoprol for T. $b$. rhodesiense; the mechanisms and drawbacks of each is discussed in a thorough review by Barret et al. ${ }^{5}$ In 2009, a nifurtimox-eflornithine combination therapy (NECT) was approved for treatment of T. b. gambiense infections. ${ }^{6}$ NECT requires $14 \mathrm{iv}$ infusions of eflornithine $\left(400 \mathrm{mg} \mathrm{kg}^{-1} \mathrm{day}^{-1}\right)$ over 7 days as well as oral nifurtimox 3 times a day for 10

Received: October 21, 2019

Published: December 17, 2019 
days. ${ }^{1,2,7,8}$ Fexinidazole, a nitroaromatic compound which recently concluded a phase II/III clinical trial for treatment of T. b. gambiense infections, demonstrated a $91 \%$ cure rate after 10 days of treatment, compared to $97 \%$ for NECT therapies. 9 This lower cure rate was deemed acceptable as fexinidazole has a more manageable dosing regimen due to it being orally bioavailable; thus fexinidazole was approved for distribution in 2019 by the European Medicines Agency, becoming the first oral therapy for HAT. ${ }^{3,10,11}$ Notably, T. b. brucei cell lines which were resistant to nifurtimox (also a nitroaromatic compound) were found to be resistant to fexinidazole. ${ }^{12}$ This cross-resistance could imply similar mechanisms of action, meaning T. $b$. gambiense strains resistant to NECT could also be resistant to fexinidazole. ${ }^{12,13}$ Acoziborole (SCYX-7158), which recently had a successful phase I clinical trial could prove to be the first, single-dose, oral therapy for HAT; however, it is not expected to conclude phase II/III trials until 2020. ${ }^{14}$ While promising, it should be noted that treatments for infectious diseases fail at a higher rate in the clinic than other drug discovery programs. ${ }^{15}$ Should resistance to NECT/ fexinidazole emerge or acoziborole fail in clinical trials, there would be few remaining treatment options for HAT.

Despite the need for treatment options, there has been little investment from the pharmaceutical industry due, in-part, to a lack of financial incentive, which led to the designation of HAT as a neglected tropical disease by the World Health Organization. ${ }^{16,17}$ With the lack of investment there has been an increasing effort in academic settings and in industrialacademic partnerships to aid the drug discovery process. ${ }^{18}$ Traditional drug discovery programs can be time-consuming and costly, often starting from a high-throughput screen (HTS) and going through target validation, hit-to-lead optimization, and in vivo testing before advancing to clinical trials. ${ }^{17}$ We hypothesize that employing one of a variety of drug repurposing strategies can help to shorten the timelines associated with this process. ${ }^{17}$

T. b. brucei expresses 176 kinases (156 which are described as eukaryotic protein kinases). Many of these are crucial to survival of the parasite, and several have human orthologs which have been pursued in drug discovery. ${ }^{19-22}$ With this in mind, we undertook a lead repurposing study against $T . b$. brucei using a biased library of known human kinase inhibitors. ${ }^{18}$ Starting from a library of 42444 kinase inhibitors, we identified 797 compounds that showed submicromolar activity against $T . b$. brucei, as well as $>100$-fold selectivity over human HepG2 cells (used as a toxicity counter screen). Compounds were clustered based on structural similarity and scored based on a variety of properties: their activity against $T$. b. brucei, rate and reversibility of action in parasite growth inhibition, and predicted CNS penetration as predicted by the multiparameter optimization (MPO) score. These properties were folded into a composite score to help prioritize starting points for medicinal chemistry optimization. ${ }^{18,23}$ One of these clusters contained a pyrazolo[1,5-b] pyridazine; a representative compound is shown in Table 1. Its properties are listed, including those known to influence drug absorption, distribution, metabolism, and excretion (ADME), such as human liver microsome (HLM) and rat hepatocyte (RH) intrinsic clearance $\left(\mathrm{Cl}_{\text {int }}\right)$, thermodynamic aqueous solubility (aq sol.), and human plasma protein binding (PPB).

On the basis of the properties of 1 , this class of pyrazolo[ $1,5-$ $b]$ pyridazines was considered a promising starting point for treatment of both stages 1 and 2 of HAT according to the
Table 1. Representative Hit from the T. b. brucei HTS ${ }^{18, a}$

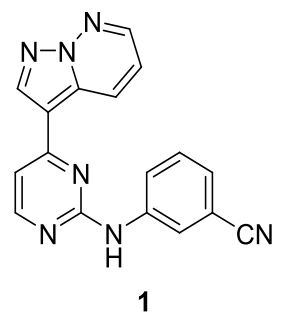

\begin{tabular}{|c|c|c|}
\hline & targeted properties & 1 \\
\hline T. b. brucei $\mathrm{pEC}_{50}$ & $>7.5$ & $8.2 \pm 0.02$ \\
\hline MRC5 $\mathrm{pTC}_{50}$ & $<5$ & $<4.3 \pm 0.00$ \\
\hline HepG2 pTC $_{50}$ & $<5$ & $<4.0 \pm 0.00$ \\
\hline aq sol. $(\mu \mathrm{M})$ & $>10$ & $<0.1$ \\
\hline MW & $\leq 360$ & 310 \\
\hline cLogP & $\leq 3$ & 2.8 \\
\hline $\operatorname{cLog} \mathrm{D}$ & $\leq 2$ & 3.6 \\
\hline MPO score & $\geq 4$ & 5.1 \\
\hline $\mathrm{RH} \mathrm{Cl}$ int & $\leq 9$ & 66 \\
\hline $\mathrm{HLM} \mathrm{Cl} \mathrm{l}_{\text {int }} * *$ & $\leq 5$ & 210 \\
\hline РPB (\%) & $\leq 95$ & 98 \\
\hline
\end{tabular}

$a_{\text {aq } \text { sol. }}=$ aqueous solubility. $\mathrm{MW}=$ molecular weight. $\mathrm{MPO}=$ multiparameter optimization. $\mathrm{RH}=$ rat hepatocyte. HLM $=$ human liver microsome. $\mathrm{PPB}=$ plasma protein binding. $*=(\mu \mathrm{L} / \mathrm{min}) / 10^{6}$ cells. $* *=(\mu \mathrm{L} / \mathrm{min}) / \mathrm{mg}$ protein.

published target product profile. ${ }^{24,25}$ This scaffold had already been investigated for activity against serine/threonine kinase (Stk1) in Staphylococcus aureus and for three human kinases: glycogen synthase kinase $3 \beta$ (GSK-3 $\beta$ ) and cyclin dependent kinases (CDK) 2 and $4 .^{26-28}$ This was unsurprising as the compound screening set used in the HTS had been selected from a library of known kinase inhibitors, and homologs of both GSK-3 and CDK have been identified in T. brucei as potential targets for drug discovery. ${ }^{21,29}$

With this information, we set out to answer the following questions. First, would we be able to discern a difference between the series activity against $T . b$. brucei cells and human enzymes GSK-3 $\beta$, CDK-2, and CDK- 4 by utilizing available data for compounds in this class? Second, would understanding this difference enable us to design compounds with improved activity against $T . b$. brucei and reduced potency against these human kinases? Third, would compounds from this class demonstrate efficacy in mouse models of trypanosome infection? While we used known human kinase inhibitor data to help guide our molecular design, we did not infer anything about the parasitic target from this information, as previous work optimizing for activity against T. brucei GSK3 has demonstrated antiparasitic activity to have arisen from a multitarget effect. ${ }^{30}$

\section{RESULTS}

Selectivity. In order to assess the difference in compound potency between T. $b$. brucei and GSK- $3 \beta$, CDK- 2 , and CDK4 , we evaluated previously reported compounds from the original HTS (and synthesized a set of previously reported analogs) with potency data against the three human kinases to see if we could find any difference in the selectivity profiles. ${ }^{26,31}$ A synthetic strategy was devised (Scheme 1) that would allow for late stage derivatization at the three positions of principal interest $\left(\mathrm{R}^{1}-\mathrm{R}^{3}\right.$, as shown in 8). Starting from 2,4- 
Scheme 1. Synthesis of Pyrazolo[1,5-b] pyridazine Analogs $^{a}$<smiles></smiles><smiles>[R]C#Cc1ccnc(Cl)n1</smiles>

${ }^{a}$ Reagents and conditions: (a) $\mathrm{POCl}_{3}, 80^{\circ} \mathrm{C}, 1 \mathrm{~h}, 70 \%$; (b) $\mathrm{NaO}^{t} \mathrm{Bu}$, $\mathrm{MeOH}$ or morpholine, $n-\mathrm{BuOH}, 80^{\circ} \mathrm{C}, 12 \mathrm{~h}, 60-100 \%$; (c) $\mathrm{HCCR}^{1}$, CuI, $\mathrm{Pd}\left(\mathrm{PPh}_{3}\right)_{2} \mathrm{Cl}_{2}$, TEA, THF, $50{ }^{\circ} \mathrm{C}, 12 \mathrm{~h}, 19-61 \%$; (d) $\mathrm{KOH}$, $\mathrm{MeOH}, \mathrm{rt}, 30 \mathrm{~min}, 94 \%$; (e) 4, hydroxylamine-O-sulfonic acid, $\mathrm{KOH}$, $\mathrm{NaHCO}_{3}, \mathrm{H}_{2} \mathrm{O}, \mathrm{DCM}, 70{ }^{\circ} \mathrm{C} \rightarrow \mathrm{rt}, 12 \mathrm{~h}, 40-84 \%$; (f) $\mathrm{NH}_{2} \mathrm{R}^{3}, n-$ $\mathrm{BuOH}, 150{ }^{\circ} \mathrm{C}, 2 \mathrm{~h}, 11-90 \%$; (g) $\mathrm{NH}_{2} \mathrm{R}^{3}, \mathrm{Pd}(\mathrm{OAc})_{2}$, BINAP or xantphos, $\mathrm{Cs}_{2} \mathrm{CO}_{3}$, dioxane, $160{ }^{\circ} \mathrm{C}, 1 \mathrm{~h}, 6-70 \%$.

dichloropyrimidine (5), a Sonogashira coupling was employed with trimethylsilylacetylene. Subsequent silyl deprotection with potassium hydroxide yielded 2-chloro-4-ethynylpyrimidine $\mathbf{6 b}$. Pyridazine 4 was reacted with hydroxylamine-O-sulfonic acid (HOSA) to generate a 1-aminopyridizinium ion in situ, which was then reacted with $6 \mathbf{b}$ in a $[3+2]$ cycloaddition reaction to form the 3-(2-chloropyrimidin-4-yl)pyrazolo[1,5-b]pyridazine intermediate 7. Subsequent nucleophilic aromatic substitution or palladium-mediated cross-coupling provided the corresponding product $\mathbf{8}^{32}$

A previously reported crystal structure of a pyrazolo $[1,5-$ b]pyridazine, 9 (Figure 1a), bound into CDK-2 (PDB code 3EID) (Figure $1 \mathrm{~b}$ and $1 \mathrm{c}$ ), indicated that substitution at the $\mathrm{R}^{1}$ and $\mathrm{R}^{2}$ positions gave the best chance to improve selectivity, due to the increased interaction with the binding pocket at these positions, while the $\mathrm{R}^{3}$ position was solvent exposed, and the binding pocket would be less sterically restrictive of the molecule. $^{31}$ Previously reported docking of a pyrazolo[1,5b]pyridazine into a GSK- $3 \beta$ crystal structure (PDB code 1GNG) predicted a similar binding mode. ${ }^{26,31}$ Available IC $_{50}$ data against all three enzymes indicated that substitution at any of these three positions could cause significant shifts in potency, but the largest decreases in potency came with substitution at the $\mathrm{R}^{1}$ and $\mathrm{R}^{2}$ positions. Armed with the published human kinase selectivity data, we compared compounds from the HTS and resynthesized a selected set of analogs from the literature. We sought to identify which substitutions could provide analogs with divergent activity for T. b. brucei over GSK-3 $\beta$, CDK-2, and CDK-4 (Table 2).

Substitution at the $\mathrm{R}^{1}$ position caused varying shifts in potency between $T . b$. brucei and the human kinases of interest. In general, substitution at this position led to a significant loss in potency against CDK-2, an observation that is consistent with the literature. ${ }^{26}$ While substituting $\mathrm{R}^{1}$ with 4(trifluoromethyl)phenyl (10f) caused a 100-fold decrease in potency against T. $b$. brucei (compared with 10e), there was a much greater impact on the potency against GSK-3 $\beta$ and CDK-2, both of which exhibited a >1000-fold decrease. Similarly, substitution with 4-methoxyphenyl (10q) caused a 10 -fold decrease in the potency against T. b. brucei (compare (a)<smiles>CN(C)C[C@H](O)COc1ccc(Nc2nccc(-c3cnn4nc(N5CCOCC5)ccc34)n2)cc1</smiles>

(b)

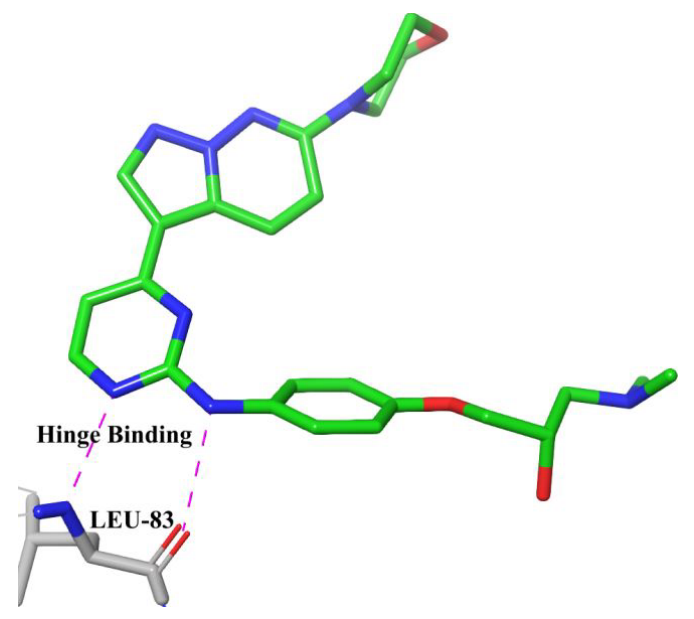

(c)

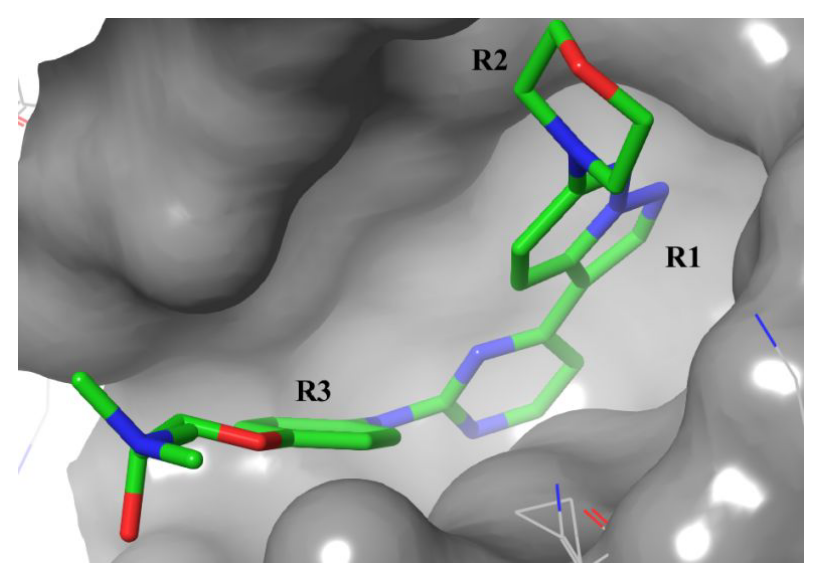

Figure 1. Previously reported crystal structure of pyrazolo[1,5$b]$ pyridazine compound, (R)-1-(dimethylamino)-3-(4-((4-(6morpholinopyrazolo $[1,5-b]$ pyridazin-3-yl)pyrimidin-2-yl)amino)phenoxy)propan-2-ol, 9 (green, stick representation), bound in human CDK-2 (gray, surface/wire representation) (PDB code 3EID): ${ }^{31}$ (a) structure of 9; (b) binding mode of 9 within the binding pocket, highlighting key hinge binding interactions with LEU83; (c) binding position of 9 showing ligand-surface interactions within $5 \AA$, displaying position of $\mathrm{R}^{1}$ inside the binding pocket.

with 10o); however the potency against GSK-3 $\beta$ and CDK-2 was decreased by $>10000$-fold. Replacement of the phenyl ring with a (smaller) cyclopropyl group (10n) also resulted in a slight decrease in the potency against $T . b$. brucei relative to the unsubstituted analog $(\mathbf{1 0 m})$. This loss in potency was again much less dramatic than observed against GSK-3 $\beta$ and CDK-2 (between 3.5 and $4 \log$ units). This indicated that while small 
Table 2. Pyrazolo[1,5-b]pyridazine Analogs with Published Human Kinase Data, Compared with Whole Cell T. $b$. brucei Potency Data ${ }^{a}$<smiles>[R]Nc1nccc(-c2c([R])nn3nc([R])ccc23)n1</smiles>

\begin{tabular}{|c|c|c|c|c|c|c|c|}
\hline ID & $\mathbf{R}^{1}$ & $\mathbf{R}^{2}$ & $\mathbf{R}^{3}$ & $\begin{array}{c}\text { T. b. brucei } \\
\operatorname{pEC}_{50}{ }^{*}\end{array}$ & $\begin{array}{c}\text { GSK-3ß } \\
\text { pIC }_{50}\end{array}$ & $\begin{array}{c}\text { CDK-2 } \\
\text { pIC }_{50}\end{array}$ & $\begin{array}{c}\text { CDK-4 } \\
\text { pIC } 50\end{array}$ \\
\hline $10 \mathrm{a}$ & $-\mathrm{H}$ & $-\mathrm{H}$ & & 5.2 & $5.0^{31}$ & $6.0^{31}$ & $6.0^{31}$ \\
\hline $10 \mathrm{~b}$ & $-\mathrm{H}$ & $-\mathrm{H}$ & & 4.8 & $4.5^{31}$ & -- & $5.5^{31}$ \\
\hline $10 \mathrm{c}$ & $-\mathrm{H}$ & $-\mathrm{H}$ & & 6.4 & $5.8^{31}$ & $6.9^{31}$ & $7.1^{31}$ \\
\hline $10 d$ & $-\mathrm{H}$ & $\mathrm{N}_{2}$ & & 6.4 & $4.6^{31}$ & -- & $6.4^{31}$ \\
\hline 10e & $-\mathrm{H}$ & $-\mathrm{H}$ & & 7.4 & $7.7^{26}$ & $8.3^{26}$ & $6.8^{26}$ \\
\hline $10 \mathrm{f}$ & & $-\mathrm{H}$ & & 5.3 & $<4.5^{26}$ & $<4.7^{26}$ & -- \\
\hline $10 \mathrm{~g}$ & $-\mathrm{H}$ & $-\mathrm{H}$ & & 5.7 & $5.2^{26}$ & -- & -- \\
\hline 1 & $-\mathrm{H}$ & $-\mathrm{H}$ & & 8.2 & $8.0^{31}$ & $8.7^{31}$ & $8.4^{31}$ \\
\hline $10 \mathrm{~h}$ & $-\mathrm{H}$ & $-\mathrm{H}$ & & 8.2 & $9.5^{31}$ & $9.5^{31}$ & $8.7^{31}$ \\
\hline $10 \mathrm{i}$ & $-\mathrm{H}$ & $-\mathrm{H}$ & & 7.6 & $8.0^{26}$ & $8.7^{26}$ & $7.2^{26}$ \\
\hline $10 \mathrm{j}$ & $-\mathrm{H}$ & 管 & & 5.7 & $7.3^{26}$ & $6.7^{26}$ & $<4.7^{26}$ \\
\hline $10 \mathrm{k}$ & $-\mathrm{H}$ & $-\mathrm{H}$ & & 7.2 & $7.9^{26}$ & $7.8^{26}$ & $7.7^{26}$ \\
\hline 101 & $-\mathrm{H}$ & $-\mathrm{H}$ & & 6.1 & $9.0^{26}$ & $8.5^{26}$ & $5.8^{26}$ \\
\hline $10 \mathrm{~m}$ & $-\mathrm{H}$ & $-\mathrm{H}$ & & 6.8 & $8.0^{26}$ & $8.7^{26}$ & -- \\
\hline $10 n$ & & $-\mathrm{H}$ & & 6.1 & $4.6^{26}$ & $<4.7^{26}$ & -- \\
\hline 100 & $-\mathrm{H}$ & $-\mathrm{H}$ & & 7.2 & $9.0^{26}$ & $8.2^{26}$ & $6.5^{26}$ \\
\hline $10 p$ & & $-\mathrm{H}$ & & 5.8 & $7.3^{26}$ & $<4.7^{26}$ & -- \\
\hline $10 q$ & & $-\mathrm{H}$ & & 6.0 & $5.3^{26}$ & $<4.7^{26}$ & -- \\
\hline $10 \mathrm{r}$ & $-\mathrm{H}$ & $-\mathrm{H}$ & & 7.8 & $7.8^{31}$ & $8.4^{31}$ & $8.2^{31}$ \\
\hline $10 \mathrm{~s}$ & $-\mathrm{H}$ & $-\mathrm{H}$ & & 6.2 & $7.3^{26}$ & $6.8^{26}$ & $5.7^{26}$ \\
\hline $10 t$ & & $-\mathrm{CH}_{3}$ & & 5.6 & $7.4^{26}$ & $<4.7^{26}$ & -- \\
\hline 9 & $-\mathrm{H}$ & & & 6.7 & $6.2^{31}$ & $6.4^{31}$ & $7.4^{31}$ \\
\hline
\end{tabular}

${ }^{a}$ Compounds without published data against a human kinase data were left blank. *Standard error of mean (SEM) within 0.17. 
substituents were tolerated, there was a sharp decrease in activity against $T$. $b$. brucei as $\mathrm{R}^{1}$ became larger. In sum, we were able to demonstrate the potential of compounds with $T$. $b$. brucei activity that is divergent from human GSK-3 $\beta$ and CDK-2 activity particularly when substituted at $\mathrm{R}^{1}$ or $\mathrm{R}^{2}$.

Substitution at the $\mathrm{R}^{2}$ position with a morpholine group (10d) led to an equipotent compound against $T$. b. brucei relative to the unsubstituted analog $(10 \mathrm{c})$, with a concomitant and significant decrease in activity against both GSK- $3 \beta$ and CDK-4 ( $\sim 10 \times$ against both). The presence of a methoxy at the $\mathrm{R}^{2}$ position $(\mathbf{1 0 j})$ led to a dramatic decrease in activity of the series against T. b. brucei; it also contributed to a complete loss of activity against CDK-4.

Substitution at $\mathrm{R}^{3}$ caused a significant shift in the potency of the series against T. $b$. brucei. Analogs with an alkyl attachment at the $\mathrm{R}^{3}$ position (10a, 10b, 10c, 10d) showed moderate inhibition of T. b. brucei, though aryl substituents (summarized in Figure 2) caused a noticeable increase in potency against $T$.

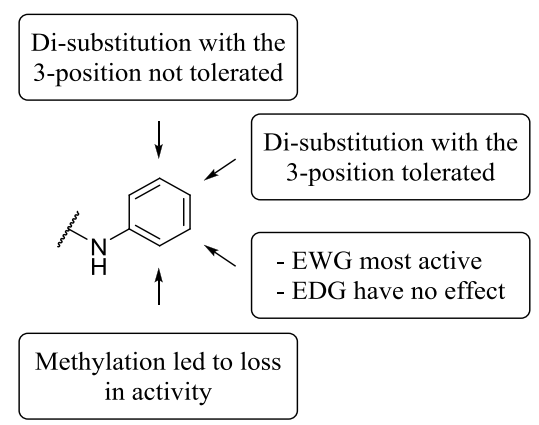

Figure 2. Preliminary structure-activity relationship (SAR) trends for substitution of aromatic rings at $\mathrm{R}^{3}$ position.

b. brucei (typified by 10e). While these changes caused significant shifts in the activity of the compounds, they did not provide any tangible selectivity improvement against the three human kinases. Substitution of the aryl ring at the 3-position with electron withdrawing groups (EWG) yielded the most potent compounds against both $T$. $b$. brucei and the human enzymes $(\mathbf{1}, \mathbf{1 0 h})$. Electron donating groups (EDG) at the 3position (10i) did not cause any significant shift in the potency, though disubstitution at the 3- and 5-positions (10k, 101) caused a noticeable decrease in activity against T. b. brucei. Disubstitution at the 3- and 4-positions of the phenyl ring (10m, 10r) did not seem to cause this shift in potency; this trend implied there were less steric restraints on the 4-position of the $\mathrm{R}^{3}$ ring for activity against both $T$. $b$. brucei cells and the human enzymes. This observation is consistent with the crystal structures for human GSK-3 $\beta$ and CDK-2, wherein the 4position of the ring points out of the binding pocket. $^{26,31}$

Curious as to the role of the pyrazolo[ $1,5-b]$ pyridazine head group in the activity of the cluster, a series of analogs was prepared to elucidate the impact of the nitrogen atom positioning within the head group upon T. b. brucei activity. The pyrazolo[1,5-a]pyridine head was synthesized via Sonogashira reaction using trimethylsilylacetylene (Scheme 2 ). Following desilylation, a $[3+2]$ dipolar cycloaddition was effected using a 1-aminopyridinium ion generated in situ to give 3-(2-chloropyrimidin-4-yl)pyrazolo[1,5-a]pyridine (11) in moderate yield. Subsequent nucleophilic aromatic substitution gave the desired products.
Scheme 2. Synthesis of Pyrazolo[1,5-a] pyridine Analogs ${ }^{a}$

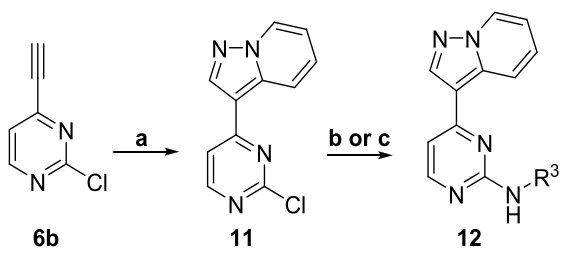

${ }^{a}$ Reagents and conditions. (a) pyridine, hydroxylamine-O-sulfonic acid, $\mathrm{KOH}, \mathrm{NaHCO}_{3}, \mathrm{H}_{2} \mathrm{O}, \mathrm{DCM}, 70{ }^{\circ} \mathrm{C} \rightarrow \mathrm{rt}, 12 \mathrm{~h}, 51 \%$; (b) $\mathrm{NH}_{2} \mathrm{R}^{3}, \mathrm{~K}_{3} \mathrm{PO}_{4}$, XPhos, $\mathrm{Pd}_{2}(\mathrm{dba})_{3}$, toluene, $110{ }^{\circ} \mathrm{C}, 12 \mathrm{~h}, 22 \%$; (c) $\mathrm{NH}_{2} \mathrm{R}^{3}, n-\mathrm{BuOH}, 110{ }^{\circ} \mathrm{C}, 12 \mathrm{~h}, 40-88 \%$.

As Table 3 shows, replacement with the pyrazolo[1,5a]pyridine head caused a decrease in potency for all four analogs compared to their matched pyrazolo[1,5-b]pyridazine counterparts. Compound 12a showed the smallest decrease in potency compared to $10 \mathrm{c}$ but was still 2 -fold less potent. The aromatic substituents at the $\mathrm{R}^{3}$ position were a minimum of 7 fold less active against T. b. brucei (12b compared to 10e), all the way up to 15 -fold less active (12d compared to 1 ). Due to this decrease in activity and no-tangible gain in the ADME profile of the series, we turned our attention to replacing the nitrogen atoms in the pyrimidine ring.

The crystal structure and docking study for both GSK-3 $\beta$ and CDK-2 indicated that the key hinge binding interaction (highlighted in Figure 1b) with the series occurred between the pyrimidine nitrogen and amine at the $\mathrm{R}^{3}$ position. ${ }^{26,31}$ If altering or removing this interaction did not cause a significant loss in potency against T. b. brucei, it would likely result in a large selectivity improvement over the human enzymes. As such, we set out to remove or replace the pyrimidine and amine nitrogens. The pyridine analogs (shown in Table 4) were prepared as shown in Scheme 1, starting from the corresponding ethynylpyridine. However, this route proved unsuccessful for the phenyl derivatives, so a new synthetic route was employed, shown in Scheme 3. Starting from pyridazine, a $[3+2]$ dipolar cycloaddition was performed with methyl propiolate. The subsequent product was saponified using potassium hydroxide to give the corresponding acid. A Hunsdiecker-like transformation provided the bromide, which was then used to perform a Suzuki-cross coupling to install the phenyl ring. ${ }^{33}$

Both pyrimidine nitrogen atoms were deemed crucial for potent activity (Table 4), as removal of either (18d, 18b) resulted in a $>10$-fold potency loss compared to the original hit (1). Removal of both nitrogen atoms (17) resulted in an additional decrease in potency. Removal of the hydrogen bond donor (HBD) and $\mathrm{R}^{3}$ ring $(16 \mathrm{a}, 18 \mathrm{a}, 18 \mathrm{c})$ resulted in a total loss of activity against $T$. $b$. brucei, though it also corresponded with a substantial increase in the solubility of all three compounds.

Given the crystal structures of GSK- $3 \beta$ and CDK-2, as well as the selectivity gained from the presence of a cyclopropyl group at the $\mathrm{R}^{1}$ position in $10 \mathrm{n}$, we performed a methyl scan around the pyrimidine ring to assess potency changes against T. b. brucei. The 5 and 6 positions on the pyrimidine ring were positioned in a similar part of the binding pocket in the GSK$3 \beta$ crystal structure as the cyclopropyl group of $10 \mathrm{n}$. Since substitution pointing into the binding pocket of the human enzymes had given selectivity for 10n, we hoped that substitution off of the pyrimidine ring would give us a similar 
Table 3. Effect of Pyrazolo[1,5-a]pyridine Head on T. b. brucei Potency ADME Properties ${ }^{b}$<smiles>[R]Nc1nccc(-c2cnn3ccccc23)n1</smiles>

\begin{tabular}{|c|c|c|c|c|c|c|c|c|}
\hline ID & $\mathbf{R}^{3}$ & $\begin{array}{l}\text { T. b. brucei } \\
\text { pEC }_{50}{ }^{*}\end{array}$ & $\begin{array}{c}\text { Aq. Sol. } \\
(\mu \mathrm{M})\end{array}$ & $\log D 7.4$ & $\underset{\mathrm{Cl}_{\text {int }}{ }^{* *}}{\mathbf{R H}}$ & $\begin{array}{l}\text { HLM } \\
\mathrm{Cl}_{\text {int }}^{* * *}\end{array}$ & $\begin{array}{l}\text { PPB } \\
(\%)\end{array}$ & $\begin{array}{l}\text { MRC5 } \\
\text { pTC }_{50}\end{array}$ \\
\hline $12 a$ & & 6.0 & 64 & 2.9 & 160 & 75 & 91 & $<4.3$ \\
\hline $12 b$ & & 6.6 & 2 & 4 & 76 & $>300$ & 99 & $<4.3$ \\
\hline $12 \mathrm{c}$ & & 6.6 & 18 & 4.3 & 140 & 220 & $>99$ & $<4.3$ \\
\hline $12 d$ & & 7.0 & $<0.9$ & $>3.9$ & 63 & $n d^{\mathrm{a}}$ & 99 & $<4.3$ \\
\hline
\end{tabular}

${ }^{a}$ Compound detected only in first sample. ${ }^{b} *=$ SEM within $0.05 . * *=(\mu \mathrm{L} / \mathrm{min}) / 10^{6}$ cells. $* * *=(\mu \mathrm{L} / \mathrm{min}) / \mathrm{mg}$ protein. nd $=$ not determined.

Table 4. T. b. brucei Activity of the Pyrimidine Replacement Analogs and the Associated ADME Data ${ }^{a}$<smiles>[R]C1[Y]C(c2cnn3ncccc23)=CC=[X]1</smiles>

\begin{tabular}{|c|c|c|c|c|c|c|c|c|c|c|}
\hline ID & $\mathbf{R}^{3}$ & $\mathbf{X}$ & $\mathbf{Y}$ & $\begin{array}{c}\text { T. b. brucei } \\
\text { pEC }_{50}{ }^{*}\end{array}$ & $\begin{array}{c}\text { Aq. Sol. } \\
(\mu \mathrm{M})\end{array}$ & $\begin{array}{c}\text { LogD } \\
7.4 \\
\end{array}$ & $\underset{\mathbf{C l}_{\text {int }}{ }^{* *}}{\mathbf{R H}}$ & $\begin{array}{l}\text { HLM } \\
\mathrm{Cl}_{\text {int }}^{* * *}\end{array}$ & $\begin{array}{l}\text { PPB } \\
(\%)\end{array}$ & \begin{tabular}{|c|} 
MRC5 \\
pTC $_{50}^{* * * *}$
\end{tabular} \\
\hline $16 a$ & $-\mathrm{H}$ & $\mathrm{CH}$ & $\mathrm{CH}$ & $<4.4$ & 850 & 2.8 & 66 & $>300$ & 91 & $<4.3$ \\
\hline 17 & & $\mathrm{CH}$ & $\mathrm{CH}$ & 5.4 & 0.7 & 4.2 & 82 & 300 & 99 & 4.7 \\
\hline $18 a$ & $-\mathrm{H}$ & $\mathrm{CH}$ & $\mathrm{N}$ & $<4.4$ & $>1000$ & 1.9 & 57 & 170 & 61 & $<4.3$ \\
\hline $18 b$ & & $\mathrm{CH}$ & $\mathrm{N}$ & 6.2 & 0.6 & 4.1 & 84 & 280 & 99 & $<4.3$ \\
\hline $18 \mathrm{c}$ & $-\mathrm{H}$ & $\mathrm{N}$ & $\mathrm{CH}$ & $<4.4$ & 990 & 1.2 & 5 & 37 & 86 & $<4.3$ \\
\hline $18 d$ & & $\mathrm{~N}$ & $\mathrm{CH}$ & 6.6 & 0.3 & 3.7 & 87 & $>300$ & 99 & $<4.3$ \\
\hline
\end{tabular}

$a_{*}=\mathrm{SEM}$ within $0.08 . * *=(\mu \mathrm{L} / \mathrm{min}) / 10^{6}$ cells. $* * *=(\mu \mathrm{L} / \mathrm{min}) / \mathrm{mg}$ protein. $* * * *=$ SEM within 0.02.

\section{Scheme 3. Synthesis of Pyrimidine Replacement Analogs Containing Phenyl Ring ${ }^{a}$}

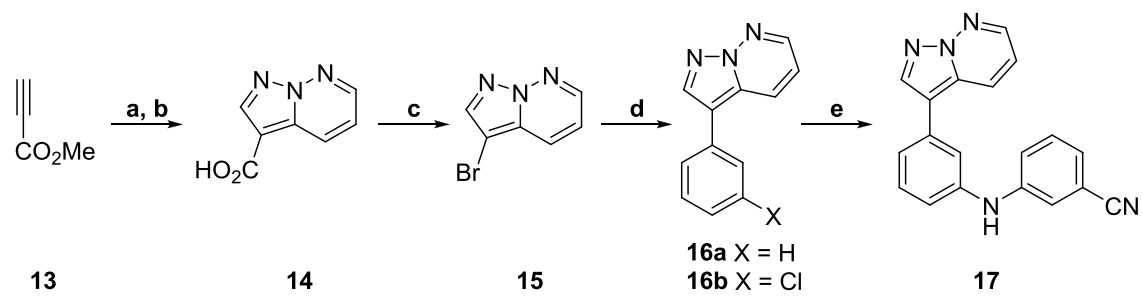

${ }^{a}$ Reagents and conditions: (a) pyridazine, hydroxylamine- $\mathrm{O}$-sulfonic acid, $\mathrm{KOH}, \mathrm{NaHCO}_{3}, \mathrm{H}_{2} \mathrm{O}, \mathrm{DCM}, 70{ }^{\circ} \mathrm{C} \rightarrow \mathrm{rt}, 12 \mathrm{~h}, 71 \%$; $(\mathrm{b}) \mathrm{NaOH}, \mathrm{H}_{2} \mathrm{O}$, $70{ }^{\circ} \mathrm{C}, 1 \mathrm{~h}, 37 \%$; (c) NBS, DMF, $25{ }^{\circ} \mathrm{C}, 3 \mathrm{~h}, 79 \%$; (d) R(BOH) $)_{2} \mathrm{Pd}(\mathrm{dppf}) \mathrm{Cl}_{2} \cdot \mathrm{DCM}, \mathrm{K}_{2} \mathrm{CO}_{3}, 3: 1$ dioxane $/ \mathrm{H}_{2} \mathrm{O}, 130{ }^{\circ} \mathrm{C}, 1 \mathrm{~h}, 15-72 \%$; (e) 3aminobenzonitrile, $\mathrm{Pd}(\mathrm{OAc})_{2}$, xantphos, $\mathrm{Cs}_{2} \mathrm{CO}_{3}$, dioxane, $160{ }^{\circ} \mathrm{C}, 1 \mathrm{~h}, 47 \%$.

selectivity advantage. By use of the same chemistry shown in Scheme 1, two analogs were prepared from the starting pyrimidines with methyl groups at the desired positions. As shown in Table 5, substitution at the 5-position of the pyrimidine ring (19b) lowered the activity of the series by 10 - fold compared to the original hit (1) whereas substitution at the 6-position (19a) resulted in a complete loss of activity. In the published crystal structures and docking models against GSK- $3 \beta$ and CDK-2, these two positions on the pyrimidine ring had pointed into the same part of the binding pocket as 
Table 5. Analogs for Methyl Scan of Pyrimidine ${ }^{a}$

\begin{tabular}{|c|c|c|c|c|c|c|c|c|c|}
\hline compd & $\mathrm{x}$ & $\mathrm{Y}$ & T. b. brucei $\mathrm{pEC}_{50}{ }^{a}$ & aq sol. $(\mu \mathrm{M})$ & $\log D_{7.4}$ & $\mathrm{RH} \mathrm{Cl} \mathrm{int}_{\text {int }} * *$ & HLM $\mathrm{Cl}_{\mathrm{int}} * * *$ & PPB (\%) & MRC5 $\mathrm{pTC}_{50}$ \\
\hline $19 a$ & $-\mathrm{H}$ & $-\mathrm{CH}_{3}$ & $<4.4$ & 0.8 & 4 & 17 & 56 & 97 & $<4.3$ \\
\hline $19 b$ & $-\mathrm{CH}_{3}$ & $-\mathrm{H}$ & 7.0 & 0.2 & 4 & 80 & 170 & 99 & $<4.3$ \\
\hline
\end{tabular}

$\mathrm{R}^{1}{ }^{26,31}$ While substitution at this position may have resulted in increased selectivity against the human enzymes, the loss in activity against T. b. brucei indicated that there was no room for substitution on this portion of the scaffold.

ADME Optimization. Armed with the knowledge of the substitutions that were tolerated at the $R^{1}$ and $R^{2}$ positions, our attention turned to the exploration of the SAR around the $\mathrm{R}^{3}$ position of our hit compound, 1, with the view to determining which $\mathrm{R}^{3}$ substituents would provide the most favorable combination of potency and ADME properties (Table 6). Compounds 20a and 20b demonstrated the importance of the HBD for potency against T. b. brucei. Removal of the nitrile (10e) did not cause any significant change in the ADME properties of the series, though replacement with a trifluoromethyl (20c) improved the clearance of the series in both $\mathrm{RH}$ and HLM, though it also resulted in a 4.4-fold decrease in potency against $T$. b. brucei. ortho-Methyl substitution of the phenyl ring $(\mathbf{1 0 g})$ provided a substantial improvement in the aqueous solubility; comparison of $\mathbf{1 0 g}$ 's melting point $\left(\mathrm{mp}=177-178{ }^{\circ} \mathrm{C}\right)$ to the melting point of 10e $\left(\mathrm{mp}=207-209^{\circ} \mathrm{C}\right)$ suggested that this increase in solubility was due to the disruption of the crystal packing of the compound. However, $10 \mathrm{~g}$ showed a decrease in the activity against $T . \quad b$. brucei. To further explore whether orthosubstitution was a viable route to improve the $\mathrm{ADME}$ properties while maintaining potency, we investigated compounds with a fluorine atom at either the 2- or 6- position of the ring (20d, 20e). These analogs did not show any significant improvement in the solubility of the series (compared with 1). Next, a number of heterocyclic replacements for the $\mathrm{R}^{3}$ phenyl group were prepared, including pyridines (20f, $20 \mathrm{~g}, \mathbf{2 0 h}$ ), pyrimidines (20i), and pyridazines (20j). The 3-pyridyl analog $(\mathbf{2 0 g})$ showed a 3.5 -fold reduction in the potency compared to $\mathbf{1}$ but showed improvements in the aqueous solubility and $\mathrm{RH} \mathrm{Cl}$ int (though $\mathrm{HLM} \mathrm{Cl}_{\text {int }}$ was still high). As blocking the 4-position of the ring (10s) had previously shown reduced HLM clearance, 20k was prepared, though it demonstrated increased HLM and RH clearance over $\mathbf{2 0 g}$. The pyrimidine analog (20i) displayed further improvement in solubility and HLM clearance, though this was at a 4.9-fold cost to potency when compared to $20 \mathrm{~g}$.

In addition to aryl substituents, a variety of alkyl substituents were explored at the $\mathrm{R}^{3}$ position, as increasing the $\mathrm{sp}^{3}$ carbon content has been previously shown to improve the aqueous solubility of a chemical series. ${ }^{34,35}$ As the steric bulk and lipophilicity of the compounds increased, an increase in potency against $T$. $b$. brucei was observed; however this increase in potency typically came with a significant reduction in solubility. Compound $\mathbf{2 0 q}$ was the most active of the compounds against T. $b$. brucei but demonstrated low solubility $(2 \mu \mathrm{M})$ and high intrinsic clearance against both $\mathrm{RH}$ and HLM. Introduction of a polar group at the 4-position was trialed as this region was known to be solvent exposed in human enzymes and we had observed a similar SAR relationship between $T . b$. brucei and the human targets at the $\mathrm{R}^{3}$ position. ${ }^{26,31}$ The introduction of a trans-alcohol (20r) greatly improved the $\mathrm{ADME}$ profile while simultaneously maintaining the activity against $T . b$. brucei $\left(\mathrm{pEC}_{50}: 6.8\right)$ as seen with 20q.

Comparison of the initial human kinase and T. $b$. brucei data indicated that substitution at the $\mathrm{R}^{1}$ position provided a promising opportunity to obtain selectivity. We also wanted to evaluate the impact that substitution at this position would have on the ADME properties of the series. Compound 21d demonstrated submicromolar activity against $T$. b. brucei and an improved ADME profile (Table 7), and the corresponding methyl ether (21e) showed that the presence of the HBD did not have a significant effect on the potency. The secondary alcohol (21f) and the isopropyl (21g) derivatives were equipotent, though a slight boost in potency was observed with the cyclopropyl $(\mathbf{2 1 h})$, suggesting that there are steric limitations. Compound $21 \mathrm{~h}$ also demonstrated an improvement in the solubility and clearance compared to $\mathbf{1}$. Additionally, the cyclopropyl group at the $\mathrm{R}^{1}$ position was previously shown to cause a total loss of activity against GSK$3 \beta$ and CDK-2 (Table 2, 10n).

Substitution at the $\mathrm{R}^{2}$ position with a morpholine or methoxy had previously shown a reduction in activity versus human CDK-2 and CDK-4; as such, we wanted to assess whether these substituents could also help improve the ADME properties of the series (Table 8 ). The morpholine was found to have no effect on the potency of the series (22c vs 1 ), though small improvements in the HLM clearance were observed. The methoxy group was found to lower potency by 1 $\log$ unit (22d vs 1) against T. b. brucei but had previously been reported to lead to a total loss in activity against CDK-4 (Table $2, \mathbf{1 0 j})$.

Given the observed trends in selectivity, activity, and ADME, we set out to make a series of combination analogs (Table 9). For the $\mathrm{R}^{1}$ position we examined the cyclopropyl group and primary alcohol as these groups were small enough to not significantly impact the potency of the molecule and could potentially provide a selectivity advantage. We selected three different $\mathrm{R}^{3}$ groups: 3-aminobenzonitrile, 3-aminopyridine, and trans-4-aminocyclohexanol based on the observed potency and ADME properties they displayed.

The series of matched analogs detailed in Table 9 gave further insight into the SAR of the cluster. At the $\mathrm{R}^{1}$ position, 
Table 6. T. $b$. brucei Activity and ADME Properties of Analogs with Substituents at the $\mathrm{R}^{3}$ Position $^{b}$

\begin{tabular}{|c|c|c|c|c|c|c|c|c|}
\hline ID & $\mathbf{R}^{3}$ & $\begin{array}{c}\text { T. b. brucei } \\
\text { pEC }_{50}{ }^{*}\end{array}$ & \begin{tabular}{|c|}
$\begin{array}{c}\text { Aq. Sol. } \\
(\mu \mathrm{M})\end{array}$ \\
\end{tabular} & $\begin{array}{c}\operatorname{LogD} \\
7.4 \\
\end{array}$ & $\underset{\mathrm{Cl}_{\text {int }}^{* *}}{\mathbf{R H}}$ & $\begin{array}{l}\text { HLM } \\
\mathrm{Cl}_{\text {int }}^{* * *}\end{array}$ & $\begin{array}{l}\text { PPB } \\
(\%)\end{array}$ & $\begin{array}{c}\text { MRC5 } \\
\text { pTC }_{50}{ }^{* * * * *}\end{array}$ \\
\hline 1 & & 8.2 & $<0.1$ & 3.6 & 66 & 210 & 98 & $<4.3$ \\
\hline 20a & & $<4.7$ & 2 & 2.4 & 41 & 13 & 90 & $<4.3$ \\
\hline $20 \mathrm{~b}$ & & 5.9 & 4 & 3.0 & 240 & 200 & 96 & $<4.6$ \\
\hline $10 \mathrm{e}$ & & 7.4 & 0.8 & 3.1 & 62 & $>300$ & 96 & $<4.3$ \\
\hline $10 \mathrm{~g}$ & & 5.7 & 38 & 3.4 & 43 & 250 & 96 & $<4.3$ \\
\hline $20 \mathrm{c}$ & & 7.6 & 3 & $>4.3$ & 30 & 76 & 100 & $<4.3$ \\
\hline 20d & & 7.2 & 0.4 & 3 & 50 & 180 & $n t$ & $<4.3$ \\
\hline $20 \mathrm{e}$ & & 7.3 & 1.4 & 3.1 & 57 & 240 & $n t$ & $<4.3$ \\
\hline $10 \mathrm{~s}$ & & 6.2 & 0.4 & 5 & 70 & 8.8 & 100 & 5.7 \\
\hline $20 \mathrm{f}$ & & 6.0 & 7 & 2.4 & 43 & 300 & 93 & $<4.3$ \\
\hline $20 \mathrm{~g}$ & & 7.7 & 6 & 2.5 & 5 & 69 & 89 & $<4.3$ \\
\hline $20 \mathrm{~h}$ & & 5.3 & 350 & -0.6 & 3.5 & 3 & 41 & $<4.4$ \\
\hline $20 \mathrm{i}$ & & 7.0 & 26 & 2 & 35 & 32 & 84 & $<4.6$ \\
\hline $20 \mathrm{j}$ & & 5.1 & 840 & -0.6 & 1.3 & 3 & 44 & $<4.3$ \\
\hline $20 \mathrm{k}$ & & 7.7 & 5 & 2.9 & 38 & 180 & 92 & $<4.3$ \\
\hline 201 & 人 & 5.9 & 170 & 1.3 & 190 & 25 & 59 & $<4.3$ \\
\hline $10 \mathrm{~b}$ & & 4.8 & 950 & 1.3 & 38 & 12 & 40 & $<4.3$ \\
\hline $20 \mathrm{~m}$ & & 5.4 & 1 & $>3.8$ & $>300$ & 110 & $n d^{\mathrm{a}}$ & $<4.3$ \\
\hline 10a & & 5.2 & 2 & 4.1 & 94 & $>300$ & 99 & $<4.3$ \\
\hline 20n & & 4.8 & 360 & 1 & 31 & 34 & 58 & $<4.3$ \\
\hline 200 & & 5.3 & 270 & 1.7 & 56 & 220 & 86 & $<4.3$ \\
\hline 20p & & 6.3 & 88 & 2.6 & 98 & $>300$ & 85 & $<4.3$ \\
\hline $20 q$ & & 6.8 & 2 & 3.7 & 140 & 240 & 97 & $<4.3$ \\
\hline $20 \mathrm{r}$ & & 6.8 & 54 & 2 & 8.7 & 14 & 68 & $<4.3$ \\
\hline
\end{tabular}

${ }^{a}$ Low recovery $/$ low stability. ${ }^{b} *=\mathrm{SEM}$ within $0.14 . * *=(\mu \mathrm{L} / \mathrm{min}) / 10^{6}$ cells. $* * *=(\mu \mathrm{L} / \mathrm{min}) / \mathrm{mg}$ protein. $* * * *=\mathrm{SEM}$ within 0.17 . nt $=$ not tested. $\mathrm{nd}=$ not determined. 
Table 7. T. b. brucei Activity of Analogs with a Substituent at the $\mathrm{R}^{1}$ Position $^{a}$<smiles>[R]c1nn2ncccc2c1-c1ccnc(Nc2cccc(C#N)c2)n1</smiles>

\begin{tabular}{|c|c|c|c|c|c|c|c|c|}
\hline ID & $\mathbf{R}^{1}$ & $\begin{array}{c}\text { T. b. brucei } \\
\text { pEC }_{50}{ }^{*}\end{array}$ & $\begin{array}{l}\text { Aq. } \\
\text { Sol. } \\
(\mu \mathrm{M})\end{array}$ & $\begin{array}{c}\operatorname{LogD} \\
7.4\end{array}$ & $\underset{\mathbf{C l}_{\text {int }}}{\mathbf{R H}}$ & $\begin{array}{c}\text { HLM } \\
\mathrm{Cl}_{\text {int }^{* * * *}}\end{array}$ & $\begin{array}{l}\text { PPB } \\
(\%)\end{array}$ & $\begin{array}{c}\text { MRC5 } \\
\text { pTC }_{50}{ }^{* * * *}\end{array}$ \\
\hline 21a & & 5.9 & $n t$ & $n t$ & $n t$ & $n t$ & $n t$ & $<4.9$ \\
\hline $21 b$ & & 6.2 & 0.2 & 4.8 & 37 & 16 & 97 & $<4.3$ \\
\hline $21 \mathrm{c}$ & & 4.9 & 12 & 2.8 & 25 & 46 & 95 & $<4.3$ \\
\hline 21d & $\mathrm{HO}$ & 6.5 & 20 & 2.5 & 63 & 240 & 93 & $<4.3$ \\
\hline $21 \mathrm{e}$ & -0 & 6.2 & 0.9 & 3.3 & 53 & $>300$ & 99 & $<4.3$ \\
\hline $21 \mathrm{f}$ & & 6.1 & 2 & 2.9 & 27 & 150 & $n t$ & $<4.3$ \\
\hline $21 \mathrm{~g}$ & & 6.2 & 28 & 4.4 & 83 & 100 & $n t$ & 4.5 \\
\hline $21 \mathrm{~h}$ & & 6.7 & 11 & $>4.2$ & 18 & 80 & $>99$ & $<4.3$ \\
\hline
\end{tabular}

$a_{*}=\mathrm{SEM}$ within $0.08 . * *=(\mu \mathrm{L} / \mathrm{min}) / 10^{6}$ cells. $* * *=(\mu \mathrm{L} / \mathrm{min}) / \mathrm{mg}$ protein. $* * * *=\mathrm{SEM}$ within $0.03 . \mathrm{nt}=$ not tested.

Table 8. T. b. brucei Activity and Associated ADME Profile of Analogs with a Substituent at the $\mathrm{R}^{2}$ Position $^{b}$<smiles>[R]c1ccc2c(-c3ccnc(Nc4ccccc4)n3)cnn2n1</smiles>

\begin{tabular}{|c|c|c|c|c|c|c|c|c|c|}
\hline ID & $\mathbf{R}^{2}$ & $\mathbf{R}^{3}$ & $\begin{array}{c}\text { T. b. brucei } \\
\text { pEC }_{50}{ }^{*}\end{array}$ & $\begin{array}{c}\text { Aq. Sol. } \\
(\mu \mathrm{M})\end{array}$ & $\begin{array}{c}\text { Log } \\
\text { D } 7.4 \\
\end{array}$ & $\underset{\mathbf{C l}_{\text {int }}}{\mathbf{R H}}$ & $\begin{array}{l}\text { HLM } \\
\mathrm{Cl}_{\text {int }}^{* * *}\end{array}$ & $\begin{array}{l}\text { PPB } \\
(\%)\end{array}$ & $\begin{array}{l}\text { MRC5 } \\
\text { pTC }_{50}\end{array}$ \\
\hline $22 a$ & & $-\mathrm{H}$ & 7.5 & $<0.9$ & 4 & 37 & 74 & 98 & $<4.3$ \\
\hline $22 b$ & & -3 -OMe & 7.7 & $<1$ & 4.1 & 47 & 72 & 99 & $<4.3$ \\
\hline $22 c$ & & $-3-\mathrm{CN}$ & 8.3 & $<19$ & $>3.7$ & 66 & 100 & $n d^{\mathrm{a}}$ & $<4.6$ \\
\hline $22 d$ & & $-3-\mathrm{CN}$ & 7.1 & $n t$ & $n t$ & $n t$ & $n t$ & $n t$ & $<4.3$ \\
\hline
\end{tabular}

${ }^{a}$ Low MS $/$ MS signal. ${ }^{b} *=$ SEM within $0.13 . * *=(\mu \mathrm{L} / \mathrm{min}) / 10^{6}$ cells. $* * *=(\mu \mathrm{L} / \mathrm{min}) / \mathrm{mg}$ protein. nd $=$ not determined. nt $=$ not tested.

analogs with a cyclopropyl group (23c, 23g, 231) were more potent than the matched pair analogs containing a primary alcohol (23b, 23f, 23m, respectively). In addition, comparison of $23 \mathrm{~g}$ and 231 to their matched pair analogs with no substitution at the $\mathrm{R}^{1}$ position (23e and $23 \mathbf{k}$, respectively) showed no decrease in potency. Interestingly this trend was not observed with compounds containing a morpholine group

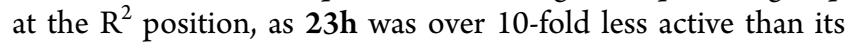
unsubstituted matched pair 23i. It should also be noted that the unsubstituted analogs at $\mathrm{R}^{1}$ showed the lowest clearance against both $\mathrm{RH}$ and HLM, indicating that $\mathrm{R}^{1}$ substituents may be a site of metabolism.

At the $\mathrm{R}^{2}$ position, analogs with a methoxy group 23a and 23g were more potent than their morpholine matched pair analogs $23 \mathrm{~b}$ and $23 \mathrm{~h}$, respectively. The reverse of this trend was seen with $23 \mathbf{k}$ compared to $23 \mathbf{j}$ (and $22 \mathrm{c}$ vs $\mathbf{2 2 d}$ previously). This reversal in trends seems to further indicate that substitution at the $\mathrm{R}^{1}$ position could have an impact on the compound-target interactions at the $\mathrm{R}^{2}$ position. Analogs with substitution at $\mathrm{R}^{1}$ appear to be more potent with a methoxy group at $\mathrm{R}^{2}$, while analogs without substitution at $\mathrm{R}^{1}$ were more potent with the morpholine. Compound 23g, with a methoxy group at $\mathrm{R}^{2}$, showed an increased potency in comparison to the analog with no substitution, 23d. Compound 23d was equipotent against $T$. b. brucei with the morpholine derivative, $\mathbf{2 3 h}$. This increase in potency from the introduction of a methoxy group can also be observed comparing 21d (Table 7) to 23a, where 23a was 4-fold more active. Overall the morpholine group was better for controlling the clearance of the series with matched analogs (23h and 23j) containing the morpholine showing lower $\mathrm{RH}$ and HLM clearance than the methoxy counterparts $(23 \mathrm{~g}$ and 23k), though all $\mathrm{R}^{2}$ analogs showed higher clearance and were less soluble than the unsubstituted analogs (23d and 20r).

A subset of these combination molecules was sent for single point inhibition assays against all three human kinases (Table 10). Analogs were prioritized based on their predicted selectivity. As expected, 23i and 23e displayed the highest 
Table 9. T. b. brucei Activity and ADME Properties for a Series of Combination Analogs, Combining Various $R^{1}, R^{2}$, and $R^{3}$ Substituents ${ }^{c}$<smiles></smiles>

\begin{tabular}{|c|c|c|c|c|c|c|c|c|c|c|}
\hline ID & $\mathbf{R}^{1}$ & $\mathbf{R}^{2}$ & $\mathbf{R}^{3}$ & $\begin{array}{c}\text { T. b. } \\
\text { brucei } \\
\text { pEC }_{50}{ }^{*}\end{array}$ & $\begin{array}{c}\text { Aq. } \\
\text { Sol. } \\
(\mu \mathrm{M})\end{array}$ & $\begin{array}{c}\text { Log } \\
\text { D } 7.4\end{array}$ & $\underset{\mathbf{C l}_{\text {int }}{ }^{* *}}{\mathbf{R H}}$ & $\begin{array}{l}\text { HLM } \\
\mathrm{Cl}_{\text {int }}{ }^{* * *}\end{array}$ & $\begin{array}{l}\text { PPB } \\
(\%)\end{array}$ & $\begin{array}{l}\text { MRC5 } \\
\text { pTC }_{50}\end{array}$ \\
\hline $23 a$ & $\mathrm{HO}$ & & & 7.2 & 0.4 & 3.6 & 170 & 45 & 99 & $<4.3$ \\
\hline $23 b$ & $\mathrm{HO}$ & & & 6.8 & $<0.3$ & 3.3 & 74 & 24 & 100 & $<4.3$ \\
\hline $23 c$ & & & & 7.1 & 0.4 & $n d^{\mathrm{a}}$ & $n t$ & 49 & 100 & $<4.3$ \\
\hline $23 d$ & & $-\mathrm{H}$ & & 6.8 & 20 & 3.3 & 16 & 60 & 98 & $<4.3$ \\
\hline $23 \mathrm{e}$ & $-\mathrm{H}$ & & & 7.2 & $n d^{b}$ & 3.4 & 15 & 120 & 97 & $<4.3$ \\
\hline $23 f$ & $\mathrm{HO}_{-}$ & & & 6.6 & 13 & 2.5 & 70 & 22 & 94 & $<4.3$ \\
\hline $23 \mathrm{~g}$ & & & & 7.2 & $n d^{b}$ & 3.6 & 110 & 230 & 100 & $<4.3$ \\
\hline $23 \mathrm{~h}$ & & & & 6.8 & 2 & 3.8 & 45 & 110 & 99 & $<4.3$ \\
\hline $23 i$ & $-\mathrm{H}$ & & & 7.9 & 0.8 & 3.1 & 13 & 53 & 94 & $<4.3$ \\
\hline $23 \mathrm{j}$ & $-\mathrm{H}$ & & & 6.8 & 7 & 2.6 & 14 & 7.3 & 88 & $<4.3$ \\
\hline $23 k$ & $-\mathrm{H}$ & 0 & & 6.3 & 8.2 & 2.6 & 90 & 52 & 85 & $<4.3$ \\
\hline 231 & & & & 6.3 & $n d^{b}$ & 3.4 & 50 & 100 & 95 & $<4.3$ \\
\hline $23 m$ & $\mathrm{HO} \&$ & & & 5.3 & $n t$ & $n t$ & $n t$ & $n t$ & $n t$ & $<4.3$ \\
\hline
\end{tabular}

${ }^{a}$ Poor MS response. ${ }^{b}$ No compound detected. ${ }^{c} *=$ SEM within $0.13 . * *=(\mu \mathrm{L} / \mathrm{min}) / 10^{6}$ cells. $* * *=(\mu \mathrm{L} / \mathrm{min}) / \mathrm{mg}$ protein. nd $=$ not determined. nt $=$ not tested.

Table 10. \% Inhibition of Selected Analogs at $1 \mu \mathrm{M}$ against Human Kinases CDK-2, CDK-4, and GSK-3 $\beta^{a}$

\begin{tabular}{cccccc} 
compd & $\begin{array}{c}\text { T. } b . \text { brucei } \\
\text { pEC }_{50}{ }^{*}\end{array}$ & $\begin{array}{c}\text { CDK-2 } \\
\text { cyclin A } \\
(\%)\end{array}$ & $\begin{array}{c}\text { CDK-2 } \\
\text { cyclin E } \\
(\%)\end{array}$ & $\begin{array}{c}\text { CDK-4 } \\
\text { cyclin D3 } \\
(\%)\end{array}$ & $\begin{array}{c}\text { GSK-3 } \beta \\
(\%)\end{array}$ \\
\hline 23a & 7.2 & 47 & 29 & 1 & 49 \\
23b & 6.8 & 46 & 54 & 32 & 75 \\
23d & 6.8 & 76 & 70 & 21 & 21 \\
23e & 7.2 & 84 & 84 & 69 & 89 \\
23g & 7.2 & 84 & 77 & 25 & 65 \\
23h & 6.8 & 67 & 49 & 26 & 34 \\
23i & 7.9 & 89 & 87 & 90 & 81
\end{tabular}

$a_{*}=$ SEM within 0.13 .

percent inhibition of all three human enzymes, reaffirming the need for substitution at $\mathrm{R}^{1}$ to provide selectivity. This was also evident when examining the selectivity trend for CDK-4, as any substitution at $\mathrm{R}^{1}$ caused a significant decrease in the activity against the enzyme. At $\mathrm{R}^{1}$ the primary alcohol (23a, 23b) was generally less active than the cyclopropyl (23d, 23g, 23h) against CDK-2. The morpholine group did appear to decrease affinity for CDK-2 provided there was substitution at $R^{1}(\mathbf{2 3 h}$, $23 \mathrm{~b}$ ). For GSK-3 $\beta$ the cyclopropyl group at $\mathrm{R}^{1}$ provided the greatest decrease in percent inhibition (23d, 23h); however the morpholine at $\mathrm{R}^{2}$ seemed to increase potency against the human enzyme. The most selective of these compounds, 23a, displayed less than $50 \%$ inhibition against all three targets; however due to a poor $\mathrm{ADME}$ profile, it was not considered for further evaluation.

With evidence of what was required to obtain selectivity in the series, we set out to determine whether the pyrazolo[1,5$b]$ pyridazine head would be efficacious in an animal model of infection. On the basis of the observed SAR and ADME data, summarized in Figure 3, we prioritized 20r and 20g for further investigation. Further studies showed that both $20 \mathrm{r}$ and $20 \mathrm{~g}$ were stable in mouse plasma (Table S3, Supporting Information), were not substrates of the cytochrome P450 isozyme 3A4, and did not induce testosterone metabolism in 


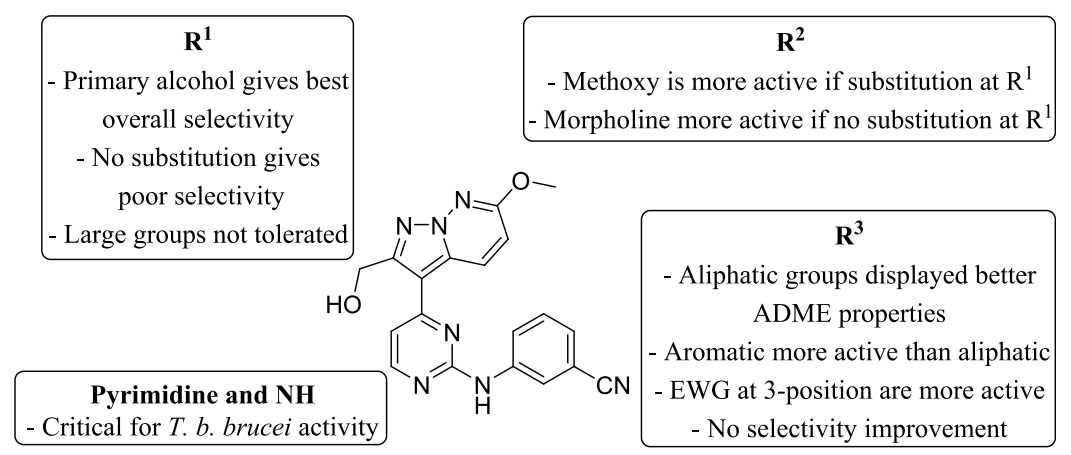

Figure 3. Summary of the SAR and structure-property relationships (SPR) for the pyrazolo[1,5-b]pyridazines.

CYP450 3A4 (Table S4, Supporting Information). Both compounds were also found to be permeable in Caco-2 cells and were not actively effluxed (Table S5, Supporting Information).

A small number of compounds were assessed to see if they were still fast acting and parasiticidal, including $20 \mathrm{r}$ and $20 \mathrm{~g}$ (Table S6, Supporting Information). Using a set of criteria previously disclosed, ${ }^{18}$ inhibitory properties of both compounds were assessed at set time points (Figure 4); we defined

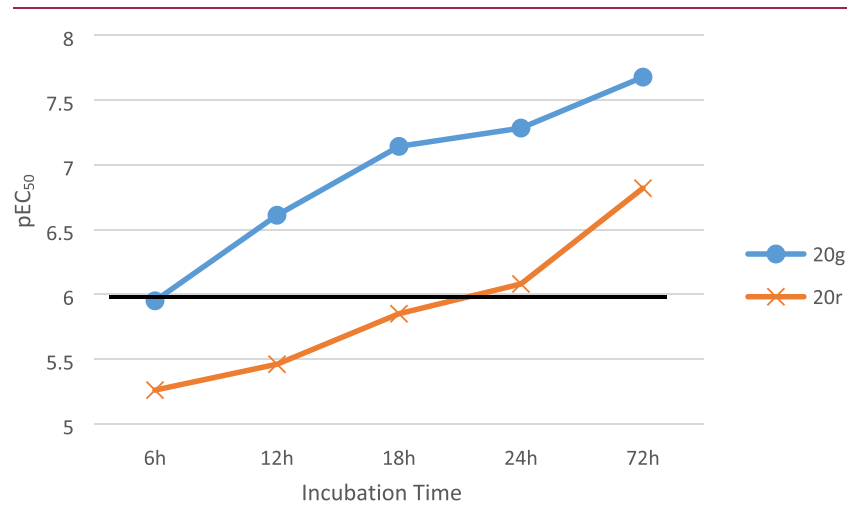

Figure 4. Rate of action of $20 \mathrm{~g}$ and $20 \mathrm{r}$, comparing $\mathrm{pEC}_{50}$ values against T. $b$. brucei following defined periods of incubation with the compound. Compounds with $\mathrm{pEC}_{50} \geq 6$ at $18 \mathrm{~h}$ were deemed fast acting (shown with a darkened line).

fast-acting compounds as having $\mathrm{pEC}_{50} \geq 6$ after $18 \mathrm{~h}$ of incubation. Given this definition, $20 \mathrm{~g}$ was fast-acting and 20r was slow acting. In parallel, washout assays were performed to assess whether the compounds were cidal or static. The compounds were incubated for $18 \mathrm{~h}$ with $T . b$. brucei and then washed out, and the parasite was incubated for $72 \mathrm{~h}$ before the wells were assayed to determine $\mathrm{pEC}_{50}$ values. Compound $20 \mathrm{~g}$ was deemed cidal as it demonstrated $\mathrm{pEC}_{99} \geq 6$ following the washout assay, whereas 20r was not cidal.

Both 20g and 20r were advanced to pharmacokinetic (PK) studies in mice, 20r for its superior ADME profile, and $20 \mathrm{~g}$ for its rate of action, cidal activity, and high potency. Although neither compound contained structural features that were indicative of selectivity over human GSK-3 $\beta, \mathrm{CDK}-2$, and CDK-4, we theorized that their ADME profiles and activity gave the highest probability of providing proof of concept efficacy. With the knowledge that inhibitors of GSK- $3 \beta$ have been shown to have no negative effect in in vivo studies and lack of activity observed against human MRC5 cells for either

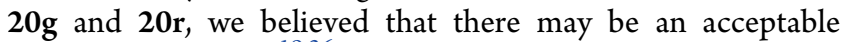
therapeutic window. ${ }^{19,36}$
Following a $10 \mathrm{mg} / \mathrm{kg}$ intraperitoneal dose (ip) into female NMRI mice, 20r (Figure S2, Supporting Information) showed low whole blood exposure, with levels above the $\mathrm{EC}_{50}$ value (152 $\mathrm{nM}$ or $47 \mathrm{ng} / \mathrm{mL}$ ) for $<4 \mathrm{~h}$ following ip administration. In addition, the compound levels were below the lower limit of quantitation in the CNS after $4 \mathrm{~h}$. We therefore deprioritized 20r for efficacy studies.

Compound $20 \mathrm{~g}$ demonstrated much better BBB penetration with similar concentrations in both the blood and brain (Figure 5). In addition, although the compound displayed a

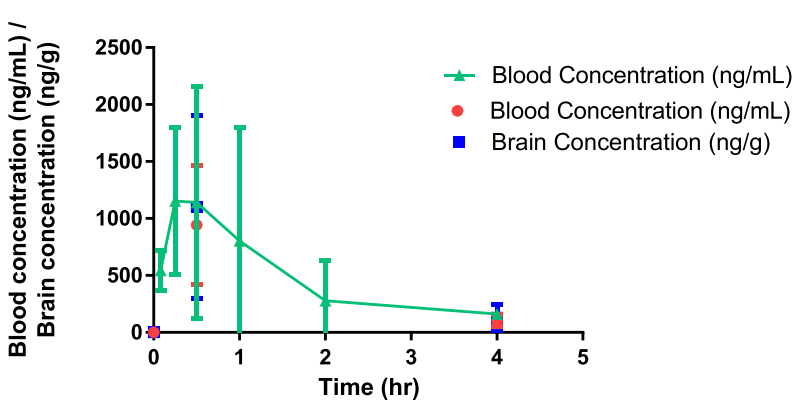

Figure 5. Peripheral blood levels of $\mathbf{2 0 g}$ after ip administration to female NMRI mice $(n=3)$ at a target dose of $10 \mathrm{mg} / \mathrm{kg}$ in $1 \%$ DMSO, 20\% Captisol in water. Individual values for each time point are represented in the plot.

short half-life $\left(t_{1 / 2}=0.68 \mathrm{~h}\right)$, blood and brain concentrations were $>10 \times \mathrm{EC}_{50}$ value $(20 \mathrm{nM}$ or $6.1 \mathrm{ng} / \mathrm{mL})$ for the entire duration of the study. Given the window for activity, as well as BBB penetration, $20 \mathrm{~g}$ was taken forward into an efficacy study.

For the efficacy study, mice were infected with T. $b$. brucei STIB795 and 3 days postinfection $\mathbf{2 0 g}$ was administered at 10 $\mathrm{mg} \mathrm{kg}^{-1}$ day $^{-1}$ ip for 5 consecutive days with daily monitoring of parasitemia levels. A significant reduction was observed in parasitemia for four of six mice, resulting in parasite concentrations dropping below detectable levels by day 4 of treatment (Table S10, Supporting Information). Despite the reduction of parasitemia, $\mathbf{2 0 g}$ showed a negligible improvement in the survival rate of the mice compared with the control group, likely due to the toxicity of the compound, as mice presented with conjunctivitis, lacrimation, facial inflammation, in addition to an inflamed liver and kidneys (Figure 6).

Due to the toxicity observed from the efficacy study, we deemed it pertinent to examine the wider kinase selectivity of $\mathbf{2 0 g}$, profiling it against a panel of human kinases (Figure 7). Of the 47 kinases $20 \mathrm{~g}$ was profiled against, 14 showed greater than $50 \%$ inhibition at $1 \mu \mathrm{M}$. Unsurprisingly, given the lack of 


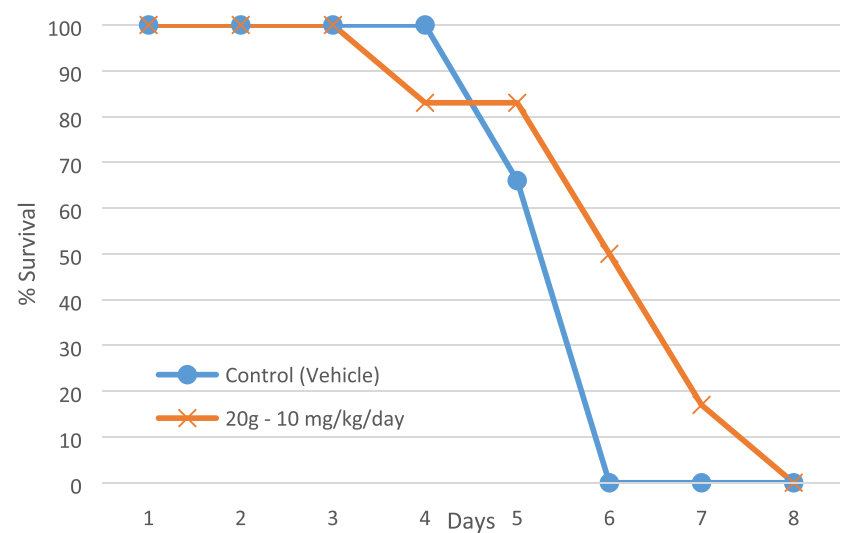

Figure 6. Effect of $20 \mathrm{~g}$ on trypanosomes in a mouse efficacy model of HAT. Percent (\%) survival rate of mice dosed ip at $10 \mathrm{mg} \mathrm{kg}^{-1} \mathrm{day}^{-1}$, compared to the control vehicle.

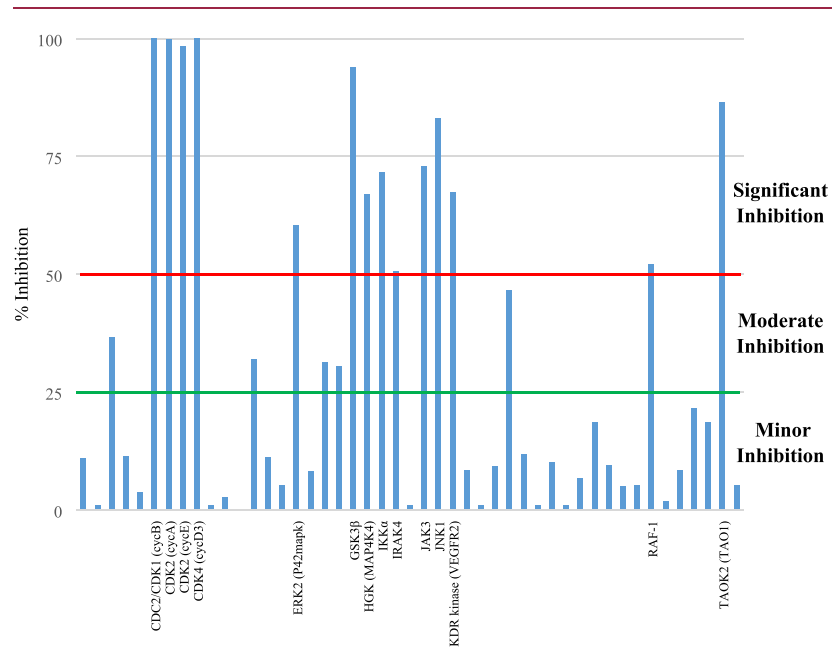

Figure 7. Percent (\%) inhibition at $1 \mu \mathrm{M} 20 \mathrm{~g}$ against human kinases. Line is drawn to show $50 \%$ inhibition of enzymes. Kinases showing significant inhibition (above 50\%) are listed on the $X$-axis. We define significant inhibition as $>50 \%$ inhibition at $1 \mu \mathrm{M}$ (red line), weak to moderate inhibition to be between $25 \%$ (green line) and $50 \%$, and insignificant inhibition to be $<25 \%$. For all values of inhibition see Table S9, Supporting Information.

substitution around $\mathrm{R}^{1}$ and $\mathrm{R}^{2}, \mathbf{2 0 g}$ still showed potent inhibition of GSK-3 $\beta$, CDK-2, and CDK-4. Further efforts in the optimization of this series would need to address this toxicity. Given the improvement in the selectivity of 23a, a more thorough investigation of substituents at $\mathrm{R}^{1}$ and $\mathrm{R}^{2}$ is warranted. The difference in toxicity, shown in Table S11, Supporting Information, against L6 $\left(20 \mathrm{~g} \mathrm{pTC}_{50}>6.2\right.$, 23a $\left.\mathrm{pTC}_{50}<4.3\right)$ and THP-1 $\left(20 \mathrm{~g} \mathrm{pTC}_{50}>6.2\right.$, 23a pTC $\left.50<4.3\right)$ indicates that these may be better cell lines to use when optimizing for toxicity.

A selection of compounds from this cluster was also screened against T. cruzi (Table S11, Supporting Information), Leishmania donovani (Table S11, Supporting Information), and adults of the flatworm pathogen, Schistosoma mansoni (Table S12, Supporting Information). Compound 10e was the most active compound against $T$. cruzi, although this was accompanied by poor selectivity versus L6 cells. While S1a was the most active against $L$. donovani and had a good selectivity profile. Further optimization to understand the SAR versus $T$. cruzi and $L$. donovani is warranted. Against $S$. mansoni, most compounds were inactive, although 10 s and S1k showed similar activities characterized by a marked decrease in movement and an inability by the parasite to adhere to the bottom of the floor of the assay well with its oral and ventral suckers. Apart from these two compounds, this cluster does not warrant further investigation as a source of antischistosomal agents.

\section{CONCLUSIONS}

Starting from a screen of 42444 known kinase inhibitors, we set out to optimize a pyrazolo[ $[1,5-b]$ pyridazine scaffold for the treatment of HAT. Using published SAR data against known human kinases GSK-3 $\beta$, CDK-2, and CDK-4, we were able to design an analog, 23a, which showed selectivity against all three human targets. As 23a did not have an ADME profile we deemed acceptable, $\mathbf{2 0} \mathrm{g}$ was taken forward into a mouse model to determine whether the series as a whole had potential to be effective in vivo. Compound $20 \mathrm{~g}$ was selected because it was fast acting, parasiticidal, had desirable ADME properties close to our targeted values, and showed good BBB penetration in the PK study. Compound $20 \mathrm{~g}$ demonstrated acceptable brain concentrations and levels in excess of $10 \times \mathrm{EC}_{50}$ for $4 \mathrm{~h}$ in the PK study and demonstrated a reduction in parasitemia in four out of the six mice tested. Although 20g's toxicity in vivo did not warrant further investigation, it highlights the promise of this series as anti-HAT agents.

\section{EXPERIMENTAL SECTION}

Strains and Media. Bloodstream Trypanosoma brucei brucei Lister 427 was cultured in Hirumi's modified Iscove's medium (HMI-9), supplemented with $10 \%$ heat-inactivated $\mathrm{FBS}$, at $37{ }^{\circ} \mathrm{C}$ and $5 \% \mathrm{CO}_{2}$ in T-25 vented flask (Corning).

MRC5-SV2 cell line (SV40-transformed human lung fibroblast cell line) was cultured in DMEM medium supplemented with 10\% FBS at $37{ }^{\circ} \mathrm{C}$ and $5 \% \mathrm{CO}_{2}$ in T-75 vented flask (Corning).

The T. cruzi Tulahuen $\mathrm{C} 4$ strain, expressing the $\beta$-galactosidase gene (LacZ) and L6 rat skeletal muscle cells, used as host cells, were cultured in RPMI-1640 supplemented with $10 \%$ iFBS, 2 mM Lglutamine, $100 \mathrm{U} / \mathrm{mL}$ penicillin, and $100 \mu \mathrm{g} / \mathrm{mL}$ streptomycin at 37 ${ }^{\circ} \mathrm{C}$ and $5 \% \mathrm{CO}_{2}$.

Leishmania donovani MHOM/ET/67/HU3 cells with the luciferase gene integrated into the parasite genome were grown at $28{ }^{\circ} \mathrm{C}$ in RPMI 1640-modified medium (Invitrogen) supplemented with $20 \%$ FBS with $100 \mathrm{mg} / \mathrm{mL}$ of hygromycin B. ${ }^{37}$

The human myelomonocytic cell line THP-1 was grown at $37^{\circ} \mathrm{C}$ and $5 \% \mathrm{CO}_{2}$ in RPMI-1640 supplemented with $10 \%$ iFBS, $2 \mathrm{mM}$ glutamate, $100 \mathrm{U} / \mathrm{mL}$ penicillin, and $100 \mathrm{mg} / \mathrm{mL}$ streptomycin. 3 $\times 10^{4}$ THP-1 cells per well in 96-well plates were differentiated to macrophages with $20 \mathrm{ng} / \mathrm{mL}$ of PMA treatment for $48 \mathrm{~h}$ followed by $24 \mathrm{~h}$ of culture in fresh medium.

Maintenance of the Schistosoma mansoni life cycle (NMRI isolate), the preparation of adult worms ( $\geq 42$-days-old), and phenotypic screens with test compounds were as described. ${ }^{38-40}$

Preparation of Compound Plates. For dose-response experiments, compound plates were prepared for each analogue by serial 3fold dilutions in $100 \%$ DMSO. Five concentration points (mammalian cytotoxicity) or ten concentration points (parasite growth inhibition) were made in a 96-well transparent Nunclon plate. Internal control (pentamidine) is included randomly for Trypanosoma brucei assay plates.

Trypanosoma brucei Growth Inhibition Assay. In order to determine the T. $b$. brucei $\mathrm{EC}_{50}$ values, an amount of $4 \mu \mathrm{L}$ per well from compound master plates was dispensed into a new plate and an amount of $96 \mu \mathrm{L}$ of HMI-9 per well was added to generate a $4 \%$ DMSO intermediate plate. Mid-log phase growth T. $b$. brucei was diluted to a working cell density of 2750 cells $/ \mathrm{mL}$ and $90 \mu \mathrm{L} /$ well 
dispensed into 96-well flat-bottom transparent assay plates (Nunc) where an amount of $10 \mu \mathrm{L} /$ well from intermediate plates was added. Final top concentration of compounds was $40 \mu \mathrm{M}$ in $0.4 \%$ DMSO per well.

Assay plates were incubated for $72 \mathrm{~h}$ at $37{ }^{\circ} \mathrm{C}$ and $5 \% \mathrm{CO}_{2}$. Four hours prior to the end of the incubation, $20 \mu \mathrm{L}$ of a $440 \mu \mathrm{M}$ resazurin solution in prewarmed HMI-9 was added to each well and incubated for another $4 \mathrm{~h}$. Fluorescence was then measured in an Infinite F200 plate reader (Tecan) at $550 \mathrm{~nm}$ (excitation filter) and $590 \mathrm{~nm}$ (emission filter). A four-parameter equation was employed to fit the dose-response curves and determine the $\mathrm{EC}_{50}$ using the SigmaPlot 13.0 software. Assays were performed in duplicate at least twice to achieve a minimal $n=3$ per dose response.

Rate of Action Assays. Mid-log T. brucei brucei cultures were diluted to the required cell density, according to the different incubation time points described. An amount of $90 \mu \mathrm{L}$ per well was dispensed in final assay plates Nunclon 96-well flat bottom Solid White, and an amount of $10 \mu \mathrm{L}$ of intermediate plates was added to each well, as described before. Four sets of assay plates were arranged to assay in order to be sequentially stopped at each indicated time point. Top and bottom rows were dismissed for compound assay, to reduce evaporation effects.

Plates were incubated at $37{ }^{\circ} \mathrm{C}$ and $5 \% \mathrm{CO}_{2}$ for the indicated time points; incubation was stopped by addition of $10 \mu \mathrm{L}$ of prewarmed Cell Titer Glo reagent (Promega), and after shaking the plates were incubated at room temperature for $10 \mathrm{~min}$ to allow the signal to settle. Plate luminescence was read on an Infinite F200 plate reader (Tecan), and raw data were processed and analyzed as previously described.

Reversibility Assays. Mid-log T. brucei brucei cultures were adjusted to a working density of $3500 \mathrm{cell} / \mathrm{mL}$. An amount of $90 \mu \mathrm{L}$ per well was dispensed in final assay plates 96-well transparent Nunclon plates, and an amount of $10 \mu \mathrm{L}$ of intermediate plates was added to each well, as described before. Top and bottom rows were dismissed for compound assay, to reduce evaporation effects.

Plates were incubated at $37{ }^{\circ} \mathrm{C}$ and $5 \% \mathrm{CO}_{2}$ for $18 \mathrm{~h}$; once drug exposure was finished, plates were spun for $5 \mathrm{~min}$ at $500 \mathrm{rpm}$ and room temperature to allow cells to settle at the well bottoms. $95 \mu \mathrm{L}$ of media was replaced with fresh prewarmed media, and the process was repeated 3 times. Finally, an amount of $10 \mu \mathrm{L}$ of each well was seeded in a new microtiter plate with $90 \mu \mathrm{L}$ of fresh prewarmed media, in duplicate. Plates were incubated for $72 \mathrm{~h}$, and viability was determined by resazurin reduction as previously described.

Cytotoxicity Assay in MRC5 Cells. Intermediate plates were made as described, adding $95 \mu \mathrm{L}$ of DMEM complete media to $5 \mu \mathrm{L}$ of compound per well setting a 5\% DMSO amount.

The log-phase MRC5 cells were removed from a T-75 TC flask using TrypLE Express (Thermo) and dispersed by gentle pipetting. Cell density was adjusted to working concentration in prewarmed DMEM medium: 25000 cells in $90 \mu \mathrm{L}$ of culture were plated in 96well transparent Nunclon plates and allowed to settle for $24 \mathrm{~h}$ at 37 ${ }^{\circ} \mathrm{C}$ and $5 \% \mathrm{CO}_{2}$. After settling incubation, an amount of $10 \mu \mathrm{L}$ of fresh made intermediate plate was added per well: final maximal concentration for compounds was $50 \mu \mathrm{M}$ in $0.5 \%$ DMSO per well. Plates were incubated for $48 \mathrm{~h}$ at $37{ }^{\circ} \mathrm{C}$ and $5 \% \mathrm{CO}_{2} .4 \mathrm{~h}$ prior to fluorescence measurement, $20 \mu \mathrm{L}$ of $500 \mu \mathrm{M}$ resazurin solution was added. Fluorescence was read in an Infinite F200 plate reader (Tecan) at $550 \mathrm{~nm}$ (excitation filter) and $590 \mathrm{~nm}$ (emission filter).

A four-parameter equation was used to fit the dose-response curves and for determination of $\mathrm{EC}_{50}$ by SigmaPlot 13.0 software. Assays were performed in duplicate at least twice for positive compounds, to achieve a minimal $n=3$ per dose response.

$\boldsymbol{\beta}$-D-Galactosidase Transgenic T. cruzi Assay. A Thermo Scientific Multidrop Combi dispenser (MTX Lab Systems, Vienna, VA) was used to dispense $90 \mu \mathrm{L}$ of $T$. cruzi amastigote-infected L6 cell culture $\left(4 \times 10^{3}\right.$ infected L6 cells per well) into 96-well Corning assay plates (Corning Inc., Corning, NY) already containing $10 \mu \mathrm{L}$ of the compounds to be screened and controls. The plates were incubated at $37^{\circ} \mathrm{C}$ for $96 \mathrm{~h}$. Then, $30 \mu \mathrm{L}$ of $100 \mu \mathrm{M}$ CPRG and $0.1 \%$ NP40 diluted with PBS were added to each well, and the plates were incubated for $4 \mathrm{~h}$ at $37{ }^{\circ} \mathrm{C}$ in the dark. Absorbance at $585 \mathrm{~nm}$ was measured in a Vmax kinetic microplate reader (Molecular Probes). Compound activities were normalized using the in-plate negative (benznidazole at $10 \mu \mathrm{g} / \mathrm{mL}$ ) and positive (0.2\% DMSO) growth controls.

Resazurin-Based L6 Assay. An amount of $100 \mu \mathrm{L}$ per well of culture medium containing the compounds and controls was added to L6 cells previously cultured $\left(4 \times 10^{3}\right.$ L6 cells per well $)$. After $72 \mathrm{~h}$ at $37{ }^{\circ} \mathrm{C}$ the medium was exchanged and the viable cell number was determined by resazurin (Sigma-Aldrich) reduction. $20 \mu \mathrm{L}$ of resazurin $(1.1 \mathrm{mg} / \mathrm{mL})$ was added to each well and incubated in the dark for $2 \mathrm{~h}$ at $37^{\circ} \mathrm{C}$. Cell viability was estimated by measuring the final fluorescence at $570-590 \mathrm{~nm}$ in an Infinite F200 plate reader (Tecan).

Cytotoxicity Assay in THP-1. Cellular toxicity of all compounds was determined using the colorimetric MTT-based assay after incubation at $37{ }^{\circ} \mathrm{C}$ for $72 \mathrm{~h}$ in the presence of increasing concentrations of compounds (final maximal concentration was 50 $\mu \mathrm{M}$ in $0.5 \%$ DMSO per well). ${ }^{41}$ The results are expressed as $\mathrm{EC}_{50}$ values, the concentration of compound that reduces cell growth by $50 \%$ versus untreated control cells. Assays were performed in duplicate at least twice to achieve a minimal $n=3$ per dose response.

Determination of $\mathrm{EC}_{50}$ in L. donovani. Macrophage-differentiated THP-1 cells were infected at a macrophage/parasite ratio of $1 / 10$ with stationary $L$. donovani promastigotes for $24 \mathrm{~h}$ at $35^{\circ} \mathrm{C}$ and $5 \% \mathrm{CO}_{2}$, and extracellular parasites were removed by washing with PBS. Infected cell cultures were then incubated with different compounds concentrations at $37{ }^{\circ} \mathrm{C}$ for $72 \mathrm{~h}$. Luminescence was measured using the Promega kit luciferase assay system (Promega, Madison, WI). Assays were performed in duplicate at least twice to achieve a minimal $n=3$ per dose response.

ADME Experiment Protocols. Aqueous pH 7.4 Solubility. Compounds are dried down from $10 \mathrm{mM}$ DMSO solutions using centrifugal evaporation technique. Phosphate buffer (0.1 M, pH 7.4) was added and StirStix inserted in the glass vials, and shaking is then performed at a constant temperature of $25{ }^{\circ} \mathrm{C}$ for $20-24 \mathrm{~h}$. This step is followed by double centrifugation with a tip wash in between, to ensure that no residues of the dried compound are interfering. The solutions are diluted before analysis and quantification using LC/MS/ MS is performed.

$\log D_{7.4}$. The distribution coefficient between 1-octanol and aqueous buffer, $\log D$, at $\mathrm{pH} 7.4$, is based on the traditional shake flask technique but with the modification of measuring compounds in mixtures of 10 at a time using UPLC with quantitative MS to measure the relative octanol and aqueous concentrations of compounds. The buffer solution used is $10 \mathrm{mM}$ sodium phosphate ( $\mathrm{pH}$ 7.4). The method has been validated for $\log D_{7.4}$ ranging from -2 to 5.0.

Human Plasma Protein Binding (PPB). PPB is determined using equilibrium dialysis (RED device) to separate free from bound compound. The amount of compound in plasma ( $1 \mathrm{mM}$ initial concentration in DMSO) and in dialysis buffer ( $\mathrm{pH} 7.4$ phosphate buffer) is measured by LC/MS/MS after $18 \mathrm{~h}$ in a dialysis chamber at $37{ }^{\circ} \mathrm{C}$. Sample levels are quantified using a seven-point calibration curve in plasma. The fraction unbound (fu, \%) is reported.

Human Liver Microsomal $\mathrm{Cl}_{\text {int }}$. In vitro intrinsic clearance was determined from human liver microsomes using a standard approach. ${ }^{42}$ Following incubation and preparation, the samples are analyzed using LC/MS/MS. Refined data are uploaded to IBIS and are displayed as $\mathrm{Cl}_{\text {int }}$ (intrinsic clearance) in $(\mu \mathrm{L} / \mathrm{min}) / \mathrm{mg}$ protein.

Rat Hepatocyte $\mathrm{Cl}_{\mathrm{int}}$. In vitro intrinsic clearance was determined from rat han Wistar hepatocytes at a final concentration of 1 million cells $/ \mathrm{mL}$. The cells were preincubated at $37{ }^{\circ} \mathrm{C}$ for $15 \mathrm{~min}$ before addition of test compound (as a $50 \mu \mathrm{M}$ stock solution) to a final concentration of $1 \mu \mathrm{M}$. The samples were analyzed using LC/MS/MS at predefined time points. Refined data were uploaded to IBIS and are displayed as $\mathrm{Cl}_{\text {int }}$ (intrinsic clearance) $(\mu \mathrm{L} / \mathrm{min}) / 1$ million cells.

Calculated $\log P$ and $\log D$ Values. Both $\log P$ and $\log D$ predictions are based on a modified version of the method ${ }^{43}$ where the predicted partition coefficients are composed of the molecules' atomic increments. 
Matrix Stability. For stability in mouse matrix, CD-1 is determined at $37{ }^{\circ} \mathrm{C}$. The assay is performed by adding $500 \mu \mathrm{M}$ compound solution to the matrix to achieve a final concentration of 2 $\mu \mathrm{M}$. Following incubation for $0,0.25,0.5,1,2$, and $4 \mathrm{~h}$, the samples are quenched and analyzed using LC/MS to determine the percentage of drug remaining.

Caco-2 Permeability. The Caco-2 permeability of test compounds is measured using an established protocol at Charles River Labs. Concentration of test compounds is determined by measuring the peak area rations at $T=0$ and $2 \mathrm{~h}$ on the apical and basolateral sides of the basal plate.

CYP Induction. CYP induction is measured using established protocols at Charles River Labs. The assay is performed by adding the test compound to the positive or negative controls, incubating for $3 \mathrm{~h}$ at $37^{\circ} \mathrm{C}$, following determination of the fold-induction relative to the vehicle control by LC/MS/MS analysis.

CYP Inhibition. CYP inhibition is measured using established protocols at Charles River Labs. A $50 \mathrm{mM}$ stock solution was prepared and serially diluted (1.5-fold and 4-fold). This was then combined with a buffer/cofactor/substrate solution before combining with the human liver microsomes. The resulting mixture was incubated at $37{ }^{\circ} \mathrm{C}$ for $30 \mathrm{~min}$ with gentle shaking before the percentage inhibition was calculated relative to zero inhibition by LC/ MS/MS analysis.

For all experiments, compounds were marked as not tested if they were not run in an assay and marked as not determined if they were run in an assay, but the result was inconclusive.

Pharmacokinetics of $20 \mathrm{r}$ and $20 \mathrm{~g}$ Following ip Administration to Female NMRI. Estimation of Brain Penetration. Compounds 20r and 20g were dosed to two groups of NMRI female mice animals (groups 1 and 2, $n=3$; groups 3 and $4, n=6$ ) by intraperitoneal (ip) route. The dosing volume was $10 \mathrm{~mL} / \mathrm{kg}$ for a total dose of $10 \mathrm{mg} / \mathrm{kg}$, and dosing formulation was prepared in $1 \%$ (v/v) dimethyl sulfoxide (DMSO)/99\% (v/v) 20\% (w/v) sulfobutyl ether- $\beta$-cyclodextrin (SBE- $\beta$-CD) (Captisol) in water. Food and tap water was available ad libitum.

For groups 1 and 2 and following ip dosing of each compound, blood samples were collected from the tail vein into capillary tubes containing K2EDTA at the following time-points: 0.0833, 0.25, 0.5, 1, $2,4,6,8$, and $24 \mathrm{~h}$ postdose.

In order to obtain simultaneous blood and brain samples, mice included in groups 3 and 4 were placed under terminal anesthetic (isoflurane) and blood samples $(0.3 \mathrm{~mL})$ collected from the retroorbital sinus into K2EDTA tubes at $0.5 \mathrm{~h}(n=3)$ and $4 \mathrm{~h}(n=3)$ after intraperitoneal administration of 20r (group 3) and 20g (group 4). Immediately following blood sample collection death was confirmed by cervical dislocation and the brain removed.

Aliquots of each blood sample were diluted with an equal volume of water. Mouse brain samples were weighed, water was added at a 1 / $2 \mathrm{w} / \mathrm{v}$ ratio (brain/water), and then the samples were homogenized. Both blood and brain samples were stored in a freezer set to maintain a temperature of $-80{ }^{\circ} \mathrm{C}$ until analysis.

Diluted blood and brain homogenates were processed under standard liquid-liquid extraction procedures using acetonitrile containing internal standard and analyzed by LC/MS/MS.

Noncompartmental analysis was performed using Phoenix pharmacokinetic software version 1.4 (Certara), and the main pharmacokinetic parameters were estimated.

Mouse Efficacy Study of Acute HAT. Six female NMRI mice (35-40 g weight from Charles River Laboratories) per group were infected by intraperitoneal (ip) injection with $10^{4}$ bloodstream forms of T. b. brucei (STIB795) strain in $0.2 \mathrm{~mL}$ of TDB glucose on day 0 . After 3 days, the infected mice were divided into two groups: control (infected mice treated with vehicle) and $20 \mathrm{~g}$ (infected mice treated with $10 \mathrm{mg} \mathrm{kg}^{-1}$ day $^{-1}$ ). On day 3 , all mice received a $0.2 \mathrm{~mL}$ ip

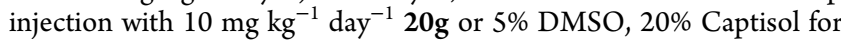
control group. This treatment was administered for 5 consecutive days. Parasitemia (measured as parasites per milliliter) was individually checked by direct microscopic counting of parasites in a Neubauer chamber using $2 \mu \mathrm{L}$ of blood from mouse tail, suspending in $100 \mu \mathrm{L}$ of TDB glucose. Mortality was checked daily up to 30 days after infection and expressed as a percentage of cumulative mortality.

Chemistry Experimental. General Methods. All starting materials were commercially obtained and were used without further purification, unless specified. Reaction solvents were purified by passage through alumina columns on a purification system manufactured by Innovative Technology (Newburyport, MA). NMR spectra were obtained on Varian NMR systems, operating at 400 or $500 \mathrm{MHz}$ for $1 \mathrm{H}$ acquisitions. LCMS analysis was performed using a Waters AllianceHT e2795 reverse phase HPLC (Waters SunFire C18 $4.6 \mathrm{~mm} \times 50 \mathrm{~mm}, 3.5 \mu \mathrm{m}$ column), with a Waters 2996 photodiode array detector scanning from 210 to $600 \mathrm{~nm}$, and Waters Micromass ZQ detector (electrospray ionization). Where required, final compounds were purified by preparative reverse phase HPLC (columns Waters Symmetry RP8 $30 \mathrm{~mm} \times 50 \mathrm{~mm}, 5 \mu \mathrm{m}$ column, or OBD RP18 $30 \mathrm{~mm} \times 50 \mathrm{~mm}, 5 \mu \mathrm{m}$ ), with a single wavelength UVvisible detector and Waters Micromass ZQ (electrospray ionization). All final compounds have purities greater than $95 \%$ based upon LCMS analysis. Melting points were obtained on a Thermo Fisher Mel-Temp apparatus. ${ }^{1} \mathrm{H}$ NMR spectra were obtained with Varian NMR systems, operating at either 400 or $500 \mathrm{MHz}$ at room temperature, using solvents from Cambridge Isotope Laboratories. Chemical shifts $(\delta, \mathrm{ppm})$ are reported relative to the solvent peak $\left(\mathrm{CDCl}_{3}, 7.26\left[{ }^{1} \mathrm{H}\right]\right.$; DMSO- $d_{6}, 2.50\left[{ }^{1} \mathrm{H}\right]$; acetone- $d_{6}, 2.05$; or $\left.\mathrm{CD}_{3} \mathrm{OD}, 3.31\left[{ }^{1} \mathrm{H}\right]\right)$. Data for ${ }^{1} \mathrm{H}$ NMR spectra are reported as follows: chemical shift (ppm), multiplicity (s for singlet, $d$ for doublet, $\mathrm{t}$ for triplet, dd for doublet of doublet, $\mathrm{m}$ for multiplet), coupling constant $(\mathrm{Hz})$, and integration.

Chemical Synthesis and Characterization. 3-((4-(Pyrazolo[1,5-b]pyridazin-3-yl)pyrimidin-2-yl)amino)benzonitrile (1). In a vial $7 \mathrm{a}(20 \mathrm{mg}, 86 \mu \mathrm{mol}), \mathrm{K}_{3} \mathrm{PO}_{4}(26 \mathrm{mg}, 121 \mu \mathrm{mol})$, XPhos $(6 \mathrm{mg}$, $13 \mu \mathrm{mol})$, bis(dibenzylideneacetone)palladium(0) $(4 \mathrm{mg}, 4.3 \mu \mathrm{mol})$, and 3 -aminobenzonitrile $(20 \mathrm{mg}, 173 \mu \mathrm{mol})$ were combined. The vial was sealed, evacuated, and backfilled with $\mathrm{N}_{2}$ three times. Degassed and anhydrous toluene $(1 \mathrm{~mL}$, dried over molecular sieves and stored under $\mathrm{N}_{2}$ ) was added to a sealed vial. The reaction was left stirring overnight at $101{ }^{\circ} \mathrm{C}$. The reaction mixture which was heterogeneous was red at room temperature, turned brown and almost clear upon heating. After $16 \mathrm{~h}$, the reaction mixture was evaporated to dryness to get a slurry which was extracted with DCM and washed with water and then dried over sodium sulfate, decanted, and concentrated to get the crude product which was purified by column chromatography using EtOAc/hex $40-100 \% 12 \mathrm{CV}$ to afford the title compound as a colorless solid (15 mg, 55\%). ${ }^{1} \mathrm{H}$ NMR $\left(500 \mathrm{MHz}\right.$, DMSO- $\left.d_{6}\right) \delta \mathrm{ppm}$ $9.96(\mathrm{~s}, 1 \mathrm{H}), 9.11-9.18(\mathrm{~m}, 1 \mathrm{H}), 8.93(\mathrm{~s}, 1 \mathrm{H}), 8.64(\mathrm{dd}, J=4.4,2.0$ $\mathrm{Hz}, 1 \mathrm{H}), 8.55(\mathrm{~d}, J=5.4 \mathrm{~Hz}, 1 \mathrm{H}), 8.38(\mathrm{br} \mathrm{s}, 1 \mathrm{H}), 7.93-7.98(\mathrm{~m}, 1$ $\mathrm{H}), 7.55(\mathrm{t}, J=8.1 \mathrm{~Hz}, 1 \mathrm{H}), 7.46-7.51(\mathrm{~m}, 2 \mathrm{H}), 7.43(\mathrm{~d}, J=7.8 \mathrm{~Hz}$, $1 \mathrm{H})$. LC-MS $(\mathrm{m} / \mathrm{z}): 314.1[\mathrm{M}+\mathrm{H}]^{+}$.

3-Chloropyridazine (3). Compound $2(470 \mathrm{mg}, 4.7 \mathrm{mmol})$ and $\mathrm{POCl}_{3}(4.5 \mathrm{~mL}, 49 \mathrm{mmol})$ were heated at $80{ }^{\circ} \mathrm{C}$ for $2 \mathrm{~h}$. The heterogeneous mixture slowly turned clear and then a dark red/brown color. The reaction mixture was then cooled to room temperature, poured into water, neutralized slowly with sat. $\mathrm{NaHCO}_{3}$, and extracted with DCM. The organic layers were washed with water, brine, dried over sodium sulfate, decanted, and concentrated to afford the crude compound as a brown solid $(360 \mathrm{mg}, 64 \%) .{ }^{1} \mathrm{H}$ NMR (500 $\mathrm{MHz}$, methanol- $\left.d_{4}\right) \delta \mathrm{ppm} 9.16(\mathrm{dd}, J=4.9,1.5 \mathrm{~Hz}, 1 \mathrm{H}), 7.84(\mathrm{dd}, J$ $=8.8,1.5 \mathrm{~Hz}, 1 \mathrm{H}), 7.74(\mathrm{dd}, J=8.8,4.9 \mathrm{~Hz}, 1 \mathrm{H})$. LC-MS $(\mathrm{m} / z)$ : $\left.114.4\left({ }^{35} \mathrm{Cl}\right), 116.5\left({ }^{37} \mathrm{Cl}\right)[\mathrm{M}+\mathrm{H}]\right]^{+}$.

4-(Pyridazin-3-yl)morpholine (4a). To a solution of 3 (360 mg, $3.1 \mathrm{mmol})$ in $n-\mathrm{BuOH}(5 \mathrm{~mL})$ was added morpholine $(0.62 \mathrm{~mL}, 7.8$ $\mathrm{mmol}$ ). The reaction mixture was heated to $80{ }^{\circ} \mathrm{C}$ for $16 \mathrm{~h}$, then cooled to room temperature. Ethyl acetate was added to the reaction mixture, and a solid precipitated from solution. The precipitate was filtered and filtrate was concentrated in vacuo, then purified by column chromatography using $\mathrm{MeOH} / \mathrm{EtOAc}, 0-20 \%, 12 \mathrm{CV}$ to afford the product as a pale-yellow solid $(430 \mathrm{mg}, 90 \%) .{ }^{1} \mathrm{H}$ NMR $(500 \mathrm{MHz}$, DMSO- $\left.d_{6}\right) \delta$ ppm $8.57(\mathrm{dd}, J=4.4,1.0 \mathrm{~Hz}, 1 \mathrm{H}), 7.39(\mathrm{dd}, J=9.3$, $4.4 \mathrm{~Hz}, 1 \mathrm{H}), 7.25(\mathrm{dd}, J=9.3,1.0 \mathrm{~Hz}, 1 \mathrm{H}), 3.71(\mathrm{t}, J=4.9 \mathrm{~Hz}, 4 \mathrm{H})$, $3.52(\mathrm{t}, J=4.9 \mathrm{~Hz}, 4 \mathrm{H})$. LC-MS $(m / z): 165.8[\mathrm{M}+\mathrm{H}]^{+}$. 
3-Methoxypyridazine (4b). Compound 3 (2.4 g, $21 \mathrm{mmol}$ ) was dissolved in $\mathrm{MeOH}(150 \mathrm{~mL})$, sodium tert-butoxide $(2.01 \mathrm{~g}, 21$ mmol) was added, and the reaction was heated to $65^{\circ} \mathrm{C}$ for $16 \mathrm{~h}$. All volatiles were removed in vacuo and then the reaction mixture was taken up in EtOAc and $\mathrm{MeOH}$ and filtered to give the product in the filtrate. All volatiles were removed in vacuo to obtain the desired compound as a red oil $(2.30 \mathrm{~g}, 99 \%) .{ }^{1} \mathrm{H}$ NMR (500 MHz, DMSO$\left.d_{6}\right) \delta$ ppm $8.87(\mathrm{dd}, J=4.4,1.5 \mathrm{~Hz}, 1 \mathrm{H}), 7.59(\mathrm{dd}, J=8.8,4.4 \mathrm{~Hz}, 1$ H), $7.19(\mathrm{dd}, J=8.8,1.5 \mathrm{~Hz}, 1 \mathrm{H}), 4.00(\mathrm{~s}, 3 \mathrm{H})$. LC-MS $(\mathrm{m} / z)$ : $110.5[\mathrm{M}+\mathrm{H}]^{+}$.

2-Chloro-4-((trimethylsilyl)ethynyl)pyrimidine (6a). In a vial 5 (500 mg, $3.36 \mathrm{mmol}$ ), dichlorobistriphenylphosphine palladium(II) $\mathrm{PdCl}_{2}\left(\mathrm{PPh}_{3}\right)_{2}(47 \mathrm{mg}, 67 \mu \mathrm{mol})$, and copper(I) iodide $(19 \mathrm{mg}, 100$ $\mu \mathrm{mol})$ were added. The vial was evacuated and backfilled with $\mathrm{N}_{2}$ three times. To this, a degassed mixture of triethylamine $(1.40 \mathrm{~mL}$, $10.1 \mathrm{mmol})$ and THF $(20 \mathrm{~mL})$ was added followed by ethynyltrimethylsilane $(0.525 \mathrm{~mL}, 3.69 \mathrm{mmol})$. The resultant solution was stirred at $50{ }^{\circ} \mathrm{C}$ overnight. The reaction mixture turned from yellow/orange in color to dark brown after addition of TMSacetylene. Upon completion, reaction mixture was concentrated to give a dark slurry which was extracted with DCM and washed with water $(3 \times 50 \mathrm{~mL})$ followed by brine, and the organic layer was dried using $\mathrm{Na}_{2} \mathrm{SO}_{4}$, decanted, and concentrated to give the crude product. Column purification was performed using EtOAc/hex, 5\% to $50 \% 12$ $\mathrm{CV}, 50-100 \% 5 \mathrm{CV}$ to afford the product as a white solid $(425 \mathrm{mg}$, $61 \%) .{ }^{1} \mathrm{H}$ NMR $(500 \mathrm{MHz}$, chloroform- $d$ ) $\delta \mathrm{ppm} 8.55(\mathrm{~d}, J=4.9 \mathrm{~Hz}$, $1 \mathrm{H}), 7.28(\mathrm{~d}, J=4.9 \mathrm{~Hz}, 1 \mathrm{H}), 0.23(\mathrm{~s}, 9 \mathrm{H}) . \mathrm{LC}-\mathrm{MS}(\mathrm{m} / \mathrm{z}): 210.9$ $\left({ }^{35} \mathrm{Cl}\right), 212.9\left({ }^{37} \mathrm{Cl}\right)[\mathrm{M}+\mathrm{H}]^{+}$.

2-Chloro-4-ethynylpyrimidine (6b). A solution of 6 a $(390 \mathrm{mg}$, $1.85 \mathrm{mmol})$ in methanol $(10 \mathrm{~mL})$ was treated with half of a stock solution of $\mathrm{KOH}(0.519 \mathrm{mg}, 9.25 \mu \mathrm{mol})$ in $1 \mathrm{~mL}$ of $\mathrm{MeOH}$. After 30 min, another half of $\mathrm{KOH}$ solution was added and the mixture was stirred at room temperature; total consumption of the reactant was observed. The mixture was concentrated to get the crude product as buff colored solid. Column purification was done using EtOAc/ hexane $10-100 \%, 15 \mathrm{CV}$ to yield the desired compound as a buff solid (200 mg, 78\%). ${ }^{1} \mathrm{H}$ NMR (500 MHz, chloroform- $d$ ) $\delta$ ppm 8.64 $(\mathrm{d}, J=4.9 \mathrm{~Hz}, 1 \mathrm{H}), 7.37(\mathrm{~d}, J=4.9 \mathrm{~Hz}, 32 \mathrm{H}), 3.48(\mathrm{~s}, 1 \mathrm{H}) . \mathrm{LC}-$ MS $(m / z): 138.6\left({ }^{35} \mathrm{Cl}\right), 140.6\left({ }^{37} \mathrm{Cl}\right)[\mathrm{M}+\mathrm{H}]^{+}$.

2-Chloro-4-((4-(trifluoromethyl)phenyl)ethynyl)pyrimidine (6c). In a vial $5(200 \mathrm{mg}, 1.34 \mathrm{mmol})$, dichlorobistriphenylphosphine palladium(II) $\mathrm{PdCl}_{2}\left(\mathrm{PPh}_{3}\right)_{2}(19 \mathrm{mg}, 27 \mu \mathrm{mol})$, triethylamine (0.6 $\mathrm{mL}, 4.03 \mathrm{mmol})$, and copper(I) iodide $(8 \mathrm{mg}, 40 \mu \mathrm{mol})$ were added followed by 1-ethynyl-4-(trifluoromethyl)benzene $(0.244 \mathrm{~mL}, 1.48$ $\mathrm{mmol})$. A degassed mixture of triethylamine $(0.6 \mathrm{~mL}, 4.03 \mathrm{mmol})$ and THF $(5 \mathrm{~mL})$ was then added. The resultant solution was stirred at 50 ${ }^{\circ} \mathrm{C}$ overnight. After completion of reaction column purification was done using EtOAc/hex, 5\% to $50 \% 12 \mathrm{CV}, 50-100 \% 5 \mathrm{CV}$ to isolate the desired compound as an orange solid (191 mg, 50\%). ${ }^{1} \mathrm{H}$ NMR $\left(500 \mathrm{MHz}\right.$, DMSO- $\left.d_{6}\right) \delta \mathrm{ppm} 8.89(\mathrm{~d}, J=5.4 \mathrm{~Hz}, 1 \mathrm{H}), 7.85-7.95$ $(\mathrm{m}, 5 \mathrm{H})$. LC-MS $(\mathrm{m} / z): 283.0\left({ }^{35} \mathrm{Cl}\right), 285.0\left({ }^{37} \mathrm{Cl}\right)[\mathrm{M}+\mathrm{H}]^{+}$.

2-Chloro-4-(cyclopropylethynyl)pyrimidine (6d). In a reaction vial 5 ( $1.0 \mathrm{~g}, 6.7 \mathrm{mmol}), \mathrm{Pd}\left(\mathrm{PPh}_{3}\right)_{2} \mathrm{Cl}_{2}(94 \mathrm{mg}, 134 \mu \mathrm{mol})$, and $\mathrm{CuI}(38 \mathrm{mg}, 201 \mu \mathrm{mol})$ were added. A degassed solution of triethylamine $(2.81 \mathrm{~mL}, 20.1 \mathrm{mmol})$ and THF $(12 \mathrm{~mL})$ was added under $\mathrm{N}_{2}$ to the reaction vial, followed by ethynylcyclopropane $(625$ $\mu \mathrm{L}, 7.38 \mathrm{mmol}$ ). The reaction mixture was heated to $50{ }^{\circ} \mathrm{C}$ for $16 \mathrm{~h}$. The reaction mixture was then filtered through Celite and washed with EtOAc. The reaction mixture was concentrated in vacuo and then subjected to column purification EtOAc/hexanes 0-25\%, to afford the desired compound as an orange solid $(1.03 \mathrm{~g}, 86 \%) .{ }^{1} \mathrm{H}$ NMR $(400 \mathrm{MHz}$, chloroform- $d) \delta \mathrm{ppm} 8.52(\mathrm{~d}, J=5.1 \mathrm{~Hz}, 1 \mathrm{H}), 7.20(\mathrm{~d}, J$ $=5.1 \mathrm{~Hz}, 1 \mathrm{H}), 1.47-1.56(\mathrm{~m}, 1 \mathrm{H}), 0.92-1.06(\mathrm{~m}, 4 \mathrm{H})$. LC-MS $(\mathrm{m} / z): 178.9\left({ }^{35} \mathrm{Cl}\right), 180.8\left({ }^{37} \mathrm{Cl}\right)[\mathrm{M}+\mathrm{H}]^{+}$.

2-Chloro-4-((4-methoxyphenyl)ethynyl)pyrimidine (6e). In a vial, 5 (0.3 g, $2.01 \mathrm{mmol})$, dichlorobistriphenylphosphine palladium(II) $\mathrm{PdCl}_{2}\left(\mathrm{PPh}_{3}\right)_{2}(28 \mathrm{mg}, 40 \mu \mathrm{mol})$, and copper(I) iodide $(11.5 \mathrm{mg}$, $60 \mu \mathrm{mol}$ ) were added, followed by a degassed mixture of triethylamine $(0.84 \mathrm{~mL})$ and THF $(5 \mathrm{~mL})$, and then 1-ethynyl-4methoxybenzene $(293 \mu \mathrm{L}, 2.2 \mathrm{mmol})$ was added. The resultant solution was stirred at $50{ }^{\circ} \mathrm{C}$ overnight. The yellow/orange reaction mixture turned dark brown after addition of TMS-acetylene and on heating. The mixture was evaporated to dryness, and then the slurry obtained was dissolved in DCM. The organic layer was washed with water and brine, then dried over sodium sulfate, decanted, and concentrated to get the crude product which was purified by column chromatography using EtOAc/hex, 5\% to $50 \% 12 \mathrm{CV}, 50-100 \% 5$ $\mathrm{CV}$ to afford the title compound as a brown solid $(0.4 \mathrm{~g}, 86 \%) .{ }^{1} \mathrm{H}$ NMR $(500 \mathrm{MHz}$, chloroform- $d$ ) $\delta$ ppm $8.59(\mathrm{~d}, J=5.4 \mathrm{~Hz}, 1 \mathrm{H})$, 7.56-7.60 (m, $2 \mathrm{H}), 7.36(\mathrm{~d}, J=5.4 \mathrm{~Hz}, 1 \mathrm{H}), 6.91-6.95(\mathrm{~m}, 2 \mathrm{H})$, $3.86(\mathrm{~s}, 3 \mathrm{H})$. LC-MS $(\mathrm{m} / z): 245.0\left({ }^{35} \mathrm{Cl}\right), 247.0\left({ }^{37} \mathrm{Cl}\right)[\mathrm{M}+\mathrm{H}]^{+}$.

4-(2-Chloropyrimidin-4-yl)-2-methylbut-3-yn-2-ol (6f). In a reaction vial 5 ( $2 \mathrm{~g}, 13.36 \mathrm{mmol})$, 2-methylbut-3-yn-2-ol ( $1.56 \mathrm{~mL}, 16$ $\mathrm{mmol}), \mathrm{Pd}\left(\mathrm{PPh}_{3}\right)_{2} \mathrm{Cl}_{2}(94 \mathrm{mg}, 134 \mu \mathrm{mol})$, and $\mathrm{CuI}(51 \mathrm{mg}, 269$ $\mu \mathrm{mol})$ were added. A degassed solution of TEA $(9.4 \mathrm{~mL})$ and THF $(50 \mathrm{~mL})$ was added under $\mathrm{N}_{2}$ to the reaction vial. The reaction mixture was heated to $60{ }^{\circ} \mathrm{C}$ for $16 \mathrm{~h}$. The reaction was then poured into water and extracted with DCM. The organic layer was washed with water and brine, then dried over sodium sulfate, decanted, concentrated to get the crude product, which was purified by column chromatography using EtOAc/hex 30-100\% $15 \mathrm{CV}$ affording the desired compound as a yellow solid $(1.60 \mathrm{~g}, 60 \%) .{ }^{1} \mathrm{H}$ NMR (500 MHz, DMSO- $\left.d_{6}\right) \delta$ ppm $8.78(\mathrm{~d}, J=5.4 \mathrm{~Hz}, 1 \mathrm{H}), 7.61(\mathrm{~d}, J=5.4 \mathrm{~Hz}$, $1 \mathrm{H}), 5.79(\mathrm{~s}, 1 \mathrm{H}), 1.48(\mathrm{~s}, 6 \mathrm{H})$. LC-MS $(\mathrm{m} / \mathrm{z}): 196.9\left({ }^{35} \mathrm{Cl}\right), 198.9$ $\left({ }^{37} \mathrm{Cl}\right)[\mathrm{M}+\mathrm{H}]^{+}$.

3-(2-Chloropyrimidin-4-yl)prop-2-yn-1-ol (6g). In a reaction vial 5 (1.0 g, $6.7 \mathrm{mmol}), \mathrm{Pd}\left(\mathrm{PPh}_{3}\right)_{2} \mathrm{Cl}_{2}(94 \mathrm{mg}, 134 \mu \mathrm{mol})$, and $\mathrm{CuI}$ $(38 \mathrm{mg}, 201 \mu \mathrm{mol})$ were added. A degassed solution of triethylamine $(3.74 \mathrm{~mL}, 26.9 \mathrm{mmol})$ and THF $(20 \mathrm{~mL})$ was added under $\mathrm{N}_{2}$ to the reaction vial, followed by propargyl alcohol $(464 \mu \mathrm{L}, 8.06 \mathrm{mmol})$. The reaction mixture was heated to $50{ }^{\circ} \mathrm{C}$ for $16 \mathrm{~h}$. The reaction was then filtered through Celite and washed with methanol. The reaction mixture was concentrated in vacuo, then subjected to column purification with $\mathrm{MeOH} / \mathrm{DCM} 0-5 \%$, to yield the desired compound as a brown solid (420 mg, 37\%). ${ }^{1} \mathrm{H}$ NMR (500 MHz, DMSO- $\left.d_{6}\right) \delta$ ppm $8.79(\mathrm{~d}, J=5.4 \mathrm{~Hz}, 1 \mathrm{H}), 7.64(\mathrm{~d}, J=5.4 \mathrm{~Hz}, 1 \mathrm{H}), 5.60(\mathrm{~d}, J=$ $5.9 \mathrm{~Hz}, 1 \mathrm{H}), 4.39(\mathrm{t}, J=5.9 \mathrm{~Hz}, 2 \mathrm{H}) . \mathrm{LC}-\mathrm{MS}(\mathrm{m} / z): 168.8\left({ }^{35} \mathrm{Cl}\right)$, $170.7\left({ }^{37} \mathrm{Cl}\right)[\mathrm{M}+\mathrm{H}]^{+}$.

2-Chloro-4-(3-methoxyprop-1-yn-1-yl)pyrimidine (6h). In a reaction vial $5(500 \mathrm{mg}, 3.36 \mathrm{mmol}), \mathrm{Pd}\left(\mathrm{PPh}_{3}\right)_{2} \mathrm{Cl}_{2}(47 \mathrm{mg}, 67$ $\mu \mathrm{mol})$, and $\mathrm{CuI}(19 \mathrm{mg}, 101 \mu \mathrm{mol})$ were added. A degassed solution of triethylamine $(1.87 \mathrm{~mL}, 13.4 \mathrm{mmol})$ and THF $(10 \mathrm{~mL})$ was added under $\mathrm{N}_{2}$ to the reaction vial, followed by 3-methoxyprop-1-yne (340 $\mu \mathrm{L}, 4.03 \mathrm{mmol})$. The reaction mixture was heated to $50^{\circ} \mathrm{C}$ for $16 \mathrm{~h}$. The reaction mixture was then filtered through Celite and concentrated in vacuo and subjected to column purification EtOAc/ hexanes $10-50 \%$, to afford the title compound as a yellow solid (183 $\mathrm{mg}, 30 \%) .{ }^{1} \mathrm{H}$ NMR (500 MHz, chloroform- $d$ ) $\delta$ ppm 8.62 (d, $J=5.4$ $\mathrm{Hz}, 1 \mathrm{H}), 7.33(\mathrm{~d}, J=5.4 \mathrm{~Hz}, 1 \mathrm{H}), 4.37(\mathrm{~s}, 2 \mathrm{H}), 3.47(\mathrm{~s}, 3 \mathrm{H})$. LCMS $(m / z): 182.8\left({ }^{35} \mathrm{Cl}\right), 184.8\left({ }^{37} \mathrm{Cl}\right)[\mathrm{M}+\mathrm{H}]^{+}$.

4-(2-Chloropyrimidin-4-yl)but-3-yn-2-ol (6i). In a reaction vial 5 (500 mg, $3.4 \mathrm{mmol}), \mathrm{Pd}\left(\mathrm{PPh}_{3}\right)_{2} \mathrm{Cl}_{2}(47 \mathrm{mg}, 67 \mu \mathrm{mol})$, and $\mathrm{CuI}(19$ $\mathrm{mg}, 100 \mu \mathrm{mol})$ were added. A degassed solution of triethylamine (1.9 $\mathrm{mL}, 13 \mathrm{mmol})$ and THF $(10 \mathrm{~mL})$ was added under $\mathrm{N}_{2}$ to the reaction vial, followed by but-3-yn-2-ol $(320 \mu \mathrm{L}, 4.0 \mathrm{mmol})$. The reaction mixture was heated to $50{ }^{\circ} \mathrm{C}$ for $16 \mathrm{~h}$. The reaction mixture was then filtered through Celite and washed with $\mathrm{MeOH}$, then concentrated in vacuo and subjected to column purification EtOAc/hexanes $20-50 \%$, to yield the desired compound as a red oil $(292 \mathrm{mg}, 48 \%) .{ }^{1} \mathrm{H}$ NMR $(500 \mathrm{MHz}$, chloroform- $d) \delta \mathrm{ppm} 8.61(\mathrm{~d}, J=4.9 \mathrm{~Hz}, 1 \mathrm{H}), 7.31(\mathrm{~d}, J$ $=4.9 \mathrm{~Hz}, 1 \mathrm{H}), 4.76-4.85(\mathrm{~m}, 1 \mathrm{H}), 1.59(\mathrm{~d}, J=6.4 \mathrm{~Hz}, 3 \mathrm{H}) . \mathrm{LC}-$ MS $(m / z): 182.9\left({ }^{35} \mathrm{Cl}\right), 184.8\left({ }^{37} \mathrm{Cl}\right)[\mathrm{M}+\mathrm{H}]^{+}$.

2-Chloro-4-(3-methylbut-1-yn-1-yl)pyrimidine (6j). In a reaction vial $5(500 \mathrm{mg}, 3.36 \mathrm{mmol}), \mathrm{Pd}\left(\mathrm{PPh}_{3}\right)_{2} \mathrm{Cl}_{2}(47 \mathrm{mg}, 67$ $\mu \mathrm{mol})$, and $\mathrm{CuI}(19 \mathrm{mg}, 101 \mu \mathrm{mol})$ were added. A degassed solution of triethylamine $(1.87 \mathrm{~mL}, 13.4 \mathrm{mmol})$ and THF $(10 \mathrm{~mL})$ was added under $\mathrm{N}_{2}$ to the reaction vial, followed by 3-methylbut-1-yne $(411 \mu \mathrm{L}$, $4.03 \mathrm{mmol}$ ). The reaction mixture was heated to $50{ }^{\circ} \mathrm{C}$ for $16 \mathrm{~h}$. The reaction mixture was then filtered through Celite and washed with EtOAc and methanol, then concentrated in vacuo and subjected to 
column purification EtOAc/hexanes $0-25 \%$, to afford the title compound as a yellow solid (487.1 mg, 80\%). ${ }^{1} \mathrm{H}$ NMR $(400 \mathrm{MHz}$, chloroform- $d$ ) $\delta$ ppm $8.55(\mathrm{~d}, J=5.1 \mathrm{~Hz}, 1 \mathrm{H}), 7.25(\mathrm{~d}, J=5.1 \mathrm{~Hz}, 1$ H), $2.76-2.94(\mathrm{~m}, 1 \mathrm{H}), 1.30(\mathrm{~d}, J=7.3 \mathrm{~Hz}, 6 \mathrm{H})$. LC-MS $(\mathrm{m} / z)$ : $180.9\left({ }^{35} \mathrm{Cl}\right), 182.8\left({ }^{37} \mathrm{Cl}\right)[\mathrm{M}+\mathrm{H}]^{+}$.

3-(2-Chloropyrimidin-4-yl)pyrazolo[1,5-b]pyridazine (7a). (Aminooxy)sulfonic acid (906 mg, $8.01 \mathrm{mmol}$ ) was dissolved in water $(5 \mathrm{~mL})$. To the clear colorless solution $2.5 \mathrm{M}$ sodium bicarbonate was added until effervescence ceased $(\mathrm{pH} \sim 5)$. The clear colorless solution was heated at $70{ }^{\circ} \mathrm{C}$, and pyridazine $(0.385 \mathrm{~mL}$, $5.34 \mathrm{mmol}$ ) was added, and then the reaction was stirred at $70{ }^{\circ} \mathrm{C}$ for $2 \mathrm{~h}$. The reaction mixture then cooled to room temperature, neutralized with $2.5 \mathrm{M}$ sodium bicarbonate (until effervescence ceased), and then a solution of $6 \mathbf{b}(185 \mathrm{mg}, 1.34 \mathrm{mmol})$ in DCM (10 $\mathrm{mL}$ ) was added followed by $\mathrm{KOH}(22 \mathrm{mg}, 3.9 \mathrm{mmol})$. Reaction mixture was stirred overnight at room temperature. After completion the reaction mixture was extracted in DCM, washed with water and brine, then dried over sodium sulfate, decanted, and concentrated to get the crude product. Column purification was performed using EtOAc/hex $30-100 \% 15 \mathrm{CV}$ to afford the compound as a red solid $(260 \mathrm{mg}, 84 \%) .{ }^{1} \mathrm{H}$ NMR (500 MHz, DMSO- $\left.d_{6}\right) \delta \mathrm{ppm} 9.04$ (s, 1 $\mathrm{H}), 8.90(\mathrm{dd}, J=8.8,2.0 \mathrm{~Hz}, 1 \mathrm{H}), 8.73(\mathrm{~d}, J=5.4 \mathrm{~Hz}, 1 \mathrm{H}), 8.69$ $(\mathrm{dd}, J=4.4,2.0 \mathrm{~Hz}, 1 \mathrm{H}), 8.07(\mathrm{~d}, J=5.4 \mathrm{~Hz}, 1 \mathrm{H}), 7.58(\mathrm{dd}, J=8.8$, $4.4 \mathrm{~Hz}, 1 \mathrm{H})$. LC-MS $(m / z): 231.9\left({ }^{35} \mathrm{Cl}\right), 234.0\left({ }^{37} \mathrm{Cl}\right)[\mathrm{M}+\mathrm{H}]^{+}$.

4-(3-(2-Chloropyrimidin-4-yl)pyrazolo[1,5-b]pyridazin-6-yl)morpholine (7b). (Aminooxy)sulfonic acid (421 mg, $3.72 \mathrm{mmol}$ ) was dissolved in $3 \mathrm{~mL}$ of water, and to the clear solution was added $2.5 \mathrm{M}$ sodium bicarbonate $(376 \mathrm{mg}, 4.47 \mathrm{mmol})$ until effervescence ceased $(\mathrm{pH} \sim 5)$. The clear colorless solution was heated at $70{ }^{\circ} \mathrm{C}$, and $4 \mathrm{a}(462 \mathrm{mg}, 2.79 \mathrm{mmol})$ was added and the reaction stirred at 70 ${ }^{\circ} \mathrm{C}$ for $2 \mathrm{~h}$. The reaction mixture was then cooled to room temperature, neutralized with $2.5 \mathrm{M}$ sodium bicarbonate (until effervescence ceased). A solution of $\mathbf{6 b}(129 \mathrm{mg}, 931 \mu \mathrm{mol})$ in DCM $(10 \mathrm{~mL})$ was added followed by $\mathrm{KOH}(104 \mathrm{mg}, 1.9 \mathrm{mmol})$, and the reaction mixture was stirred at room temperature for $16 \mathrm{~h}$. DCM layer turned dark pink. Reaction mixture was then extracted into DCM, and the organic layer was washed with water and brine, then dried over sodium sulfate, decanted, and concentrated to get the crude product, which was purified by column chromatography using EtOAc/hex, $20-100 \% 15 \mathrm{CV}$, to obtain the desired compound as a white solid (160 mg, 5\%). ${ }^{1} \mathrm{H}$ NMR (500 MHz, chloroform- $d$ ) $\delta$ ppm 8.77 (d, $J=$ $9.8 \mathrm{~Hz}, 1 \mathrm{H}), 8.51(\mathrm{~d}, J=5.4 \mathrm{~Hz}, 1 \mathrm{H}), 8.29(\mathrm{~s}, 1 \mathrm{H}), 7.45(\mathrm{~d}, J=5.4$ $\mathrm{Hz}, 1 \mathrm{H}), 7.03(\mathrm{~d}, J=9.8 \mathrm{~Hz}, 1 \mathrm{H}), 3.88(\mathrm{t}, J=4.9 \mathrm{~Hz}, 4 \mathrm{H}), 3.62(\mathrm{t}, J$ $=4.9 \mathrm{~Hz}, 4 \mathrm{H}) . \mathrm{LC}-\mathrm{MS}(\mathrm{m} / \mathrm{z}): 317.0\left({ }^{35} \mathrm{Cl}\right), 318.9\left({ }^{37} \mathrm{Cl}\right)[\mathrm{M}+\mathrm{H}]^{+}$.

3-(2-Chloropyrimidin-4-yl)-6-methoxypyrazolo[1,5-b]pyridazine (7c). (Aminooxy)sulfonic acid $(1.90 \mathrm{~g}, 16.8 \mathrm{mmol}$ ) was dissolved in $4 \mathrm{~mL}$ of water, and to the clear solution was added saturated sodium bicarbonate until effervescence ceased $(\mathrm{pH} \sim 6)$. The clear colorless solution was heated at $70{ }^{\circ} \mathrm{C}$, and $4 \mathbf{b}(1.24 \mathrm{~g}, 11.2$ mmol) was added in $20 \mathrm{~mL}$ of water, and the reaction mixture was stirred at $70{ }^{\circ} \mathrm{C}$ for $2 \mathrm{~h}$. The reaction mixture was then cooled to room temperature, neutralized with saturated sodium bicarbonate (until effervescence ceased), and then a solution of $6 \mathbf{b}(622 \mathrm{mg}, 4.49$ $\mathrm{mmol})$ in DCM $(80 \mathrm{~mL})$ and $\mathrm{KOH}(252 \mathrm{mg}, 4.49 \mathrm{mmol})$ were added, and the reaction mixture was stirred at room temperature for $16 \mathrm{~h}$. The reaction mixture was diluted with DCM and water and extracted. The organic layer was washed with water and brine, then dried over sodium sulfate, filtered, and evaporated to get the crude product which was purified by column chromatography using EtOAc/ hex $20-50 \%$ to provide the desired product as a brown solid $(496 \mathrm{mg}$, 42\%). ${ }^{1} \mathrm{H}$ NMR (500 MHz, DMSO- $\left.d_{6}\right) \delta$ ppm $8.82(\mathrm{~s}, 1 \mathrm{H}), 8.73(\mathrm{~d}$, $J=9.3 \mathrm{~Hz}, 1 \mathrm{H}), 8.70(\mathrm{~d}, J=5.4 \mathrm{~Hz}, 1 \mathrm{H}), 8.01(\mathrm{~d}, J=5.4 \mathrm{~Hz}, 1 \mathrm{H})$, $7.27(\mathrm{~d}, J=9.3 \mathrm{~Hz}, 1 \mathrm{H}), 4.02(\mathrm{~s}, 3 \mathrm{H}) . \mathrm{LC}-\mathrm{MS}(\mathrm{m} / \mathrm{z}): 262.0\left({ }^{35} \mathrm{Cl}\right)$, $264.1\left({ }^{37} \mathrm{Cl}\right)[\mathrm{M}+\mathrm{H}]^{+}$.

3-(2-Chloropyrimidin-4-yl)-2-(4-(trifluoromethyl)phenyl)pyrazolo[1,5-b]pyridazine (7d). (Aminooxy)sulfonic acid (559 $\mathrm{mg}, 4.95 \mathrm{mmol}$ ) was dissolved in $5 \mathrm{~mL}$ of water, and to the clear solution was added $2.5 \mathrm{M}$ sodium bicarbonate until effervescence ceased $(\mathrm{pH} \sim 5)$. The clear colorless solution was heated to $70{ }^{\circ} \mathrm{C}$, and pyridazine $(0.24 \mathrm{~mL}, 3.30 \mathrm{mmol})$ was added, and the reaction mixture was stirred at $70{ }^{\circ} \mathrm{C}$ for $2 \mathrm{~h}$. Reaction mixture was cooled to room temperature, neutralized with $2.5 \mathrm{M}$ sodium bicarbonate (until effervescence ceased), then solution of $6 \mathrm{c}(223 \mathrm{mg}, 824 \mu \mathrm{mol})$ in DCM $(4 \mathrm{~mL})$ and $\mathrm{KOH}(138 \mathrm{mg}, 2.46 \mathrm{mmol})$ were added, and the reaction mixture was then stirred overnight at room temperature. After $16 \mathrm{~h}$ the reaction mixture was extracted in DCM, washed the DCM layer with water, brine and dried over sodium sulfate, decanted, and concentrated to get the crude product which was purified by column chromatography using EtOAc/hex, 10-100\% 15 CV to afford the title compound as a bronze solid $(150 \mathrm{mg}, 47 \%) .{ }^{1} \mathrm{H}$ NMR (500 $\left.\mathrm{MHz}, \mathrm{DMSO}-d_{6}\right) \delta \mathrm{ppm} 8.78$ (dd, $J=9.3,2.0 \mathrm{~Hz}, 1 \mathrm{H}$ ), 8.74 (dd, $J=$ 4.4, $2.0 \mathrm{~Hz}, 1 \mathrm{H}), 8.62(\mathrm{~d}, J=5.4 \mathrm{~Hz}, 1 \mathrm{H}), 7.91(\mathrm{~s}, 4 \mathrm{H}), 7.60$ (dd, $J$ $=9.3,4.4 \mathrm{~Hz}, 1 \mathrm{H}), 7.23(\mathrm{~d}, J=5.4 \mathrm{~Hz}, 1 \mathrm{H})$. LC-MS $(\mathrm{m} / z): 314.9$ $\left({ }^{35} \mathrm{Cl}\right), 317.0\left({ }^{37} \mathrm{Cl}\right)[\mathrm{M}+\mathrm{H}]^{+}$.

3-(2-Chloropyrimidin-4-yl)-2-cyclopropylpyrazolo[1,5-b]pyridazine (7e). (Aminooxy)sulfonic acid (1.63 g, $14.4 \mathrm{mmol}$ ) was dissolved in $4 \mathrm{~mL}$ of water, and saturated sodium bicarbonate was added to the clear solution until effervescence ceased $(\mathrm{pH} \sim 6)$. The clear colorless solution was heated to $70{ }^{\circ} \mathrm{C}$, and pyridazine $(693 \mu \mathrm{L}$, $9.60 \mathrm{mmol}$ ) was added, and the reaction mixture was stirred at $70{ }^{\circ} \mathrm{C}$ for $2 \mathrm{~h}$. The reaction mixture was then cooled to room temperature, neutralized with saturated sodium bicarbonate (until effervescence ceased), then a solution of $6 \mathrm{~d}(429 \mathrm{mg}, 2.4 \mathrm{mmol})$ in DCM $(7 \mathrm{~mL})$ was added followed by $\mathrm{KOH}(135 \mathrm{mg}, 2.4 \mathrm{mmol})$, and the reaction was stirred for $16 \mathrm{~h}$ at room temperature. Partial conversion to product was observed, so additional $\mathrm{KOH}(270 \mathrm{mg}, 4.8 \mathrm{mmol})$ was added. The reaction was stirred for another $8 \mathrm{~h}$. After $8 \mathrm{~h}$ another 2 equiv of $\mathrm{KOH}(270 \mathrm{mg}, 4.8 \mathrm{mmol})$ was added, and the reaction continued stirring for an additional $16 \mathrm{~h}$. The reaction mixture was diluted with DCM and washed with water and brine, then dried over magnesium sulfate, filtered, and evaporated to get the crude product which was purified by column chromatography using EtOAc/hex 20$50 \%$ and providing the desired compound as a pale-yellow solid (472.5 mg, 72\%). ${ }^{1} \mathrm{H}$ NMR (500 MHz, chloroform- $d$ ) $\delta$ ppm 8.92 $(\mathrm{dd}, J=8.8,2.0 \mathrm{~Hz}, 1 \mathrm{H}), 8.61(\mathrm{~d}, J=5.4 \mathrm{~Hz}, 1 \mathrm{H}), 8.38(\mathrm{dd}, J=4.4$, $2.0 \mathrm{~Hz}, 1 \mathrm{H}), 7.87$ (d, $J=5.4 \mathrm{~Hz}, 1 \mathrm{H}), 7.24(\mathrm{dd}, J=8.8,4.4 \mathrm{~Hz}, 1$ $\mathrm{H}), 2.23-2.31(\mathrm{~m}, 1 \mathrm{H}), 1.29-1.35(\mathrm{~m}, 2 \mathrm{H}), 1.17-1.23(\mathrm{~m}, 2 \mathrm{H})$. LC-MS $(\mathrm{m} / z): 272.1\left({ }^{35} \mathrm{Cl}\right), 274.1\left({ }^{37} \mathrm{Cl}\right)[\mathrm{M}+\mathrm{H}]^{+}$.

3-(2-Chloropyrimidin-4-yl)-2-(4-methoxyphenyl)pyrazolo[1,5-b]pyridazine (7f). (Aminooxy)sulfonic acid (1.11 g, 9.81 $\mathrm{mmol}$ ) was dissolved in $5 \mathrm{~mL}$ of water, and to the clear solution $2.5 \mathrm{M}$ sodium bicarbonate was added until effervescence ceased $(\mathrm{pH}$ $\sim 5$ ). The clear colorless solution was heated to $70^{\circ} \mathrm{C}$, and pyridazine $(0.471 \mathrm{~mL}, 6.54 \mathrm{mmol})$ was added, then the reaction mixture was stirred at $70{ }^{\circ} \mathrm{C}$ for $2 \mathrm{~h}$. The reaction cooled to room temperature, neutralized with $2.5 \mathrm{M}$ sodium bicarbonate (until effervescence ceased), and then a solution of $6 \mathrm{e}(0.4 \mathrm{~g}, 1.63 \mathrm{mmol})$ in DCM (20 $\mathrm{mL}$ ) was added followed by $\mathrm{KOH}(275 \mathrm{mg}, 4.9 \mathrm{mmol})$. The reaction mixture was stirred at room temperature for $16 \mathrm{~h}$, then diluted with DCM, washed with water and brine, then dried over sodium sulfate, decanted, and concentrated to get the crude product, which was purified by column chromatography using EtOAc/hex, 10-100\% 15 CV to provide the title compound as an off-white solid (35 mg, 46\% based on recovered starting material). Recovered $345 \mathrm{mg}$ of unreacted starting material. ${ }^{1} \mathrm{H}$ NMR $(500 \mathrm{MHz}$, chloroform- $d$ ) $\delta$ ppm 8.96 (dd, $J=8.8,2.0 \mathrm{~Hz}, 1 \mathrm{H}), 8.46(\mathrm{dd}, J=4.9,2.0 \mathrm{~Hz}, 1 \mathrm{H}), 8.34(\mathrm{~d}, J=5.4$ $\mathrm{Hz}, 1 \mathrm{H}), 7.58-7.61(\mathrm{~m}, 2 \mathrm{H}), 7.13(\mathrm{~d}, J=5.4 \mathrm{~Hz}, 1 \mathrm{H}), 7.02-7.05$ $(\mathrm{m}, 2 \mathrm{H}), 6.89-6.95(\mathrm{~m}, 1 \mathrm{H}), 3.91(\mathrm{~s}, 3 \mathrm{H})$. LC-MS $(\mathrm{m} / z): 338.0$ $\left.\left({ }^{35} \mathrm{Cl}\right), 339.9\left({ }^{37} \mathrm{Cl}\right)[\mathrm{M}+\mathrm{H}]\right]^{+}$.

2-(3-(2-Chloropyrimidin-4-yl)pyrazolo[1,5-b]pyridazin-2-yl)propan-2-ol (7g). (Aminooxy)sulfonic acid $(280 \mathrm{mg}, 2.47 \mathrm{mmol}$ ) was dissolved in $5 \mathrm{~mL}$ of water, and to the clear solution $2.5 \mathrm{M}$ sodium bicarbonate was added until effervescence ceased $(\mathrm{pH} \sim 5)$. The clear colorless solution was heated to $70^{\circ} \mathrm{C}$, and pyridazine (119 $\mu \mathrm{L}, 1.65 \mathrm{mmol}$ ) was added, and the reaction mixture was stirred at 70 ${ }^{\circ} \mathrm{C}$ for $2 \mathrm{~h}$. The reaction was then cooled to room temperature, neutralized with $2.5 \mathrm{M}$ sodium bicarbonate (until effervescence ceased), and then a solution of $6 \mathrm{f}(81 \mathrm{mg}, 412 \mu \mathrm{mol})$ in DCM (10 $\mathrm{mL}$ ) was added followed by $\mathrm{KOH}(69 \mathrm{mg}, 1.2 \mathrm{mmol})$, and the reaction mixture was stirred at room temperature. After $16 \mathrm{~h}$ the 
reaction mixture was diluted with DCM and washed with water and brine, then dried over sodium sulfate, decanted, and concentrated to get the crude product which was purified by column chromatography using EtOAc/hex $30-100 \% 15 \mathrm{CV}$ to afford the title compound as a brown solid (47 mg, 40\%). ${ }^{1} \mathrm{H}$ NMR (500 MHz, DMSO- $\left.d_{6}\right) \delta \mathrm{ppm}$ $8.77(\mathrm{~d}, J=5.4 \mathrm{~Hz}, 1 \mathrm{H}), 8.73(\mathrm{dd}, J=9.3,1.5 \mathrm{~Hz}, 1 \mathrm{H}), 8.62(\mathrm{dd}, J=$ 4.4, $1.5 \mathrm{~Hz}, 1 \mathrm{H}), 8.54(\mathrm{~d}, J=5.4 \mathrm{~Hz}, 1 \mathrm{H}), 7.49$ (dd, $J=9.3,4.4 \mathrm{~Hz}$, $1 \mathrm{H}), 5.95(\mathrm{~s}, 1 \mathrm{H}), 1.64(\mathrm{~s}, 6 \mathrm{H}) . \mathrm{LC}-\mathrm{MS}(\mathrm{m} / \mathrm{z}): 290.0\left({ }^{35} \mathrm{Cl}\right), 292.1$ $\left({ }^{37} \mathrm{Cl}\right)[\mathrm{M}+\mathrm{H}]^{+}$

(3-(2-chloropyrimidin-4-yl)pyrazolo[1,5-b]pyridazin-2-yl)methanol (7h). (Aminooxy)sulfonic acid (450 mg, $4.0 \mathrm{mmol}$ ) was dissolved in $3 \mathrm{~mL}$ of water, and to the clear solution $2.5 \mathrm{M}$ sodium bicarbonate was added until effervescence ceased $(\mathrm{pH} \sim 5)$. The clear colorless solution was heated to $70{ }^{\circ} \mathrm{C}$, and pyridazine $(190 \mu \mathrm{L}, 2.7$ mmol) was added, and the reaction mixture was stirred at $70{ }^{\circ} \mathrm{C}$ for 2 $\mathrm{h}$. The reaction was then cooled to room temperature, neutralized with $2.5 \mathrm{M}$ sodium bicarbonate (until effervescence ceased), and then a solution of $6 \mathrm{~g}(110 \mathrm{mg}, 670 \mu \mathrm{mol})$ in DCM $(5 \mathrm{~mL})$ was added followed by $\mathrm{KOH}(40 \mathrm{mg}, 670 \mu \mathrm{mol})$, and the reaction mixture was stirred at room temperature. After $16 \mathrm{~h}$ the reaction mixture was diluted with DCM and washed with water and brine, then dried over sodium sulfate. The reaction was filtered and evaporated in vacuo, then subjected to column purification using $\mathrm{MeOH} / \mathrm{DCM} 2 \%$ to afford the title compound as an orange solid (34 mg, 20\%). ${ }^{1} \mathrm{H}$ NMR $\left(500 \mathrm{MHz}, \mathrm{DMSO}-d_{6}\right) \delta \mathrm{ppm} 8.87(\mathrm{dd}, J=8.8,2.0 \mathrm{~Hz}, 1 \mathrm{H}), 8.78(\mathrm{~d}$, $J=5.4 \mathrm{~Hz}, 1 \mathrm{H}), 8.67(\mathrm{dd}, J=4.4,2.0 \mathrm{~Hz}, 1 \mathrm{H}), 8.05(\mathrm{~d}, J=5.4 \mathrm{~Hz}, 1$ $\mathrm{H}), 7.56(\mathrm{dd}, J=8.8,4.4 \mathrm{~Hz}, 1 \mathrm{H}), 5.76(\mathrm{t}, J=5.4 \mathrm{~Hz}, 1 \mathrm{H}), 4.89(\mathrm{~d}, J$ $=5.4 \mathrm{~Hz}, 1 \mathrm{H}) . \mathrm{LC}-\mathrm{MS}(\mathrm{m} / z): 262.0\left({ }^{35} \mathrm{Cl}\right), 264.0\left({ }^{37} \mathrm{Cl}\right)[\mathrm{M}+\mathrm{H}]^{+}$.

3-(2-Chloropyrimidin-4-yl)-2-(methoxymethyl)pyrazolo[1,5-b]pyridazine (7i). (Aminooxy)sulfonic acid (680 mg, 6.01 $\mathrm{mmol}$ ) was dissolved in $5 \mathrm{~mL}$ of water, and saturated sodium bicarbonate was added to the clear solution until effervescence ceased $(\mathrm{pH} \sim 6)$. The clear colorless solution was heated at $70{ }^{\circ} \mathrm{C}$, and pyridazine $(289 \mu \mathrm{L}, 4.01 \mathrm{mmol})$ was added, and the reaction was stirred at $70{ }^{\circ} \mathrm{C}$ for $2 \mathrm{~h}$. Reaction mixture was then cooled to room temperature, neutralized with saturated sodium bicarbonate (until effervescence ceased), and then a solution of $6 \mathrm{~h}(183 \mathrm{mg}, 1.0 \mathrm{mmol})$ in DCM $(10 \mathrm{~mL})$ was added followed by KOH $(112 \mathrm{mg}, 2.0 \mathrm{mmol})$, and the reaction was stirred for $16 \mathrm{~h}$ at room temperature. The reaction mixture was extracted in DCM washed with water and brine, then dried over magnesium sulfate, filtered, and evaporated to get the crude product which was purified by column chromatography using EtOAc/hex 20-50\% to yield the title compound as a white solid (229 mg, 83\%). ${ }^{1} \mathrm{H}$ NMR (500 MHz, DMSO- $\left.d_{6}\right) \delta$ ppm 8.86 (dd, $J=9.3$, $2.0 \mathrm{~Hz}, 1 \mathrm{H}), 8.79(\mathrm{~d}, J=5.4 \mathrm{~Hz}, 1 \mathrm{H}), 8.69(\mathrm{dd}, J=4.4,2.0 \mathrm{~Hz}, 1$ $\mathrm{H}), 7.85(\mathrm{~d}, J=5.4 \mathrm{~Hz}, 1 \mathrm{H}), 7.57(\mathrm{dd}, J=9.3,4.4 \mathrm{~Hz}, 1 \mathrm{H}), 4.86(\mathrm{~s}$, $2 \mathrm{H}), 3.37(\mathrm{~s}, 3 \mathrm{H})$. LC-MS $(m / z): 276.0\left({ }^{35} \mathrm{Cl}\right), 278.0\left({ }^{37} \mathrm{Cl}\right)[\mathrm{M}+$ $\mathrm{H}]^{+}$.

1-(3-(2-Chloropyrimidin-4-yl)pyrazolo[1,5-b]pyridazin-2-yl)ethan-1-ol (7j). (Aminooxy)sulfonic acid (1.1 g, $9.6 \mathrm{mmol}$ ) was dissolved in $5 \mathrm{~mL}$ of water, and saturated sodium bicarbonate was added to the clear solution until effervescence ceased $(\mathrm{pH} \sim 6)$. The clear colorless solution was heated at $70{ }^{\circ} \mathrm{C}$, and pyridazine $(462 \mu \mathrm{L}$, $6.4 \mathrm{mmol}$ ) was added, and the reaction mixture was stirred at $70{ }^{\circ} \mathrm{C}$ for $2 \mathrm{~h}$. Reaction mixture was then cooled to room temperature, neutralized with saturated sodium bicarbonate (until effervescence ceased), and then a solution of $6 \mathbf{i}(292 \mathrm{mg}, 1.6 \mathrm{mmol})$ in DCM (15 $\mathrm{mL}$ ) was added followed by $\mathrm{KOH}(180 \mathrm{mg}, 3.2 \mathrm{mmol})$, and the reaction was stirred for $16 \mathrm{~h}$ at room temperature. The reaction mixture was diluted with DCM and washed with water and brine, then dried over magnesium sulfate, filtered, and evaporated to get the crude product which was purified by column chromatography using EtOAc/hex $45-80 \%$ to provide the title compound as a yellow solid $(290 \mathrm{mg}, 66 \%) .{ }^{1} \mathrm{H}$ NMR $\left(500 \mathrm{MHz}, \mathrm{DMSO}-d_{6}\right) \delta \mathrm{ppm} 8.81(\mathrm{~d}, J=$ $9.3 \mathrm{~Hz}, 1 \mathrm{H}), 8.76(\mathrm{~d}, J=5.4 \mathrm{~Hz}, 1 \mathrm{H}), 8.63-8.67(\mathrm{~m}, 1 \mathrm{H}), 8.18(\mathrm{~d}, J$ $=5.4 \mathrm{~Hz}, 1 \mathrm{H}), 7.52(\mathrm{dd}, J=9.3,4.4 \mathrm{~Hz}, 1 \mathrm{H}), 5.76(\mathrm{~d}, J=6.4 \mathrm{~Hz}, 1$ $\mathrm{H}), 5.25$ (quin, $J=6.4 \mathrm{~Hz}, 1 \mathrm{H}), 1.62(\mathrm{~d}, J=6.4 \mathrm{~Hz}, 3 \mathrm{H})$. LC-MS $(\mathrm{m} / z): 276.0\left({ }^{35} \mathrm{Cl}\right), 278.0\left({ }^{37} \mathrm{Cl}\right)[\mathrm{M}+\mathrm{H}]^{+}$.

3-(2-Chloropyrimidin-4-yl)-2-isopropylpyrazolo[1,5-b]pyridazine (7k). (Aminooxy)sulfonic acid (1.83 g, $16.2 \mathrm{mmol}$ ) was dissolved in $5 \mathrm{~mL}$ of water, and saturated sodium bicarbonate was added to the clear solution until effervescence ceased $(\mathrm{pH} \sim 6)$. The clear colorless solution was heated to $70{ }^{\circ} \mathrm{C}$, and pyridazine $(778 \mu \mathrm{L}$, $10.8 \mathrm{mmol}$ ) was added, and the reaction mixture was stirred at $70^{\circ} \mathrm{C}$ for $2 \mathrm{~h}$. The reaction mixture was then cooled to room temperature, neutralized with saturated sodium bicarbonate (until effervescence ceased), and then a solution of $\mathbf{6 j}(487 \mathrm{mg}, 2.7 \mathrm{mmol})$ in DCM (7 $\mathrm{mL}$ ) was added followed by $\mathrm{KOH}(151 \mathrm{mg}, 2.70 \mathrm{mmol})$, and the reaction was stirred for $16 \mathrm{~h}$ at room temperature, at which point more $\mathrm{KOH}$ (302 mg, $5.4 \mathrm{mmol}$ ) was added and stirring was continued for another $3 \mathrm{~h}$. The reaction mixture was diluted with DCM, washed with water and brine, then dried over magnesium sulfate, filtered, and evaporated to get the crude product which was purified by column chromatography using EtOAc/hex $20-50 \%$ to afford the title compound as a yellow solid $(471 \mathrm{mg}, 64 \%) .{ }^{1} \mathrm{H}$ NMR $(500 \mathrm{MHz}$, chloroform- $d) \delta \mathrm{ppm} 8.87(\mathrm{~d}, J=9.3 \mathrm{~Hz}, 1 \mathrm{H}), 8.60(\mathrm{~d}, J$ $=5.4 \mathrm{~Hz}, 1 \mathrm{H}), 8.39(\mathrm{~d}, J=4.4 \mathrm{~Hz}, 1 \mathrm{H}), 7.47(\mathrm{~d}, J=5.4 \mathrm{~Hz}, 1 \mathrm{H})$, $7.24(\mathrm{dd}, J=9.3,4.4 \mathrm{~Hz}, 1 \mathrm{H}), 3.54-3.64(\mathrm{~m}, 1 \mathrm{H}), 1.51(\mathrm{~d}, J=6.4$ $\mathrm{Hz}, 6 \mathrm{H}) . \mathrm{LC}-\mathrm{MS}(\mathrm{m} / z): 274.1\left({ }^{35} \mathrm{Cl}\right), 276.0\left({ }^{37} \mathrm{Cl}\right)[\mathrm{M}+\mathrm{H}]^{+}$.

(3-(2-Chloropyrimidin-4-yl)-6-methoxypyrazolo[ $1,5-b]-$ pyridazin-2-yl)methanol (7l). (Aminooxy)sulfonic acid $(909 \mathrm{mg}$, $8.0 \mathrm{mmol}$ ) was dissolved in $4 \mathrm{~mL}$ of water, and saturated sodium bicarbonate was added to the clear solution until effervescence ceased $(\mathrm{pH} \sim 6)$. The clear colorless solution was heated at $70{ }^{\circ} \mathrm{C}$, and $\mathbf{4 b}$ $(590 \mathrm{mg}, 5.36 \mathrm{mmol}$ ) was added, then the reaction was stirred at 70 ${ }^{\circ} \mathrm{C}$ for $2 \mathrm{~h}$. The reaction mixture was then cooled to room temperature, neutralized with saturated sodium bicarbonate (until effervescence ceased), and then a solution of $6 \mathrm{~g}(452 \mathrm{mg}, 2.68 \mathrm{mmol})$ in DCM $(15 \mathrm{~mL})$ was added followed by $\mathrm{KOH}(150 \mathrm{mg}, 2.7 \mathrm{mmol})$, and the reaction mixture was stirred for $16 \mathrm{~h}$ at room temperature. The reaction mixture was diluted with DCM and washed with water and brine, then dried over sodium sulfate, filtered, and evaporated to get the crude product which was purified by column chromatography using EtOAc/hex 25-50\% to afford the title compound as an orange solid $(265 \mathrm{mg}, 34 \%) .{ }^{1} \mathrm{H}$ NMR $\left(500 \mathrm{MHz}, \mathrm{DMSO}-d_{6}\right) \delta \mathrm{ppm} 8.76$ (d, $J=5.4 \mathrm{~Hz}, 1 \mathrm{H}), 8.72(\mathrm{~d}, J=9.8 \mathrm{~Hz}, 1 \mathrm{H}), 8.01(\mathrm{~d}, J=5.4 \mathrm{~Hz}, 1 \mathrm{H})$, $7.25(\mathrm{~d}, J=9.8 \mathrm{~Hz}, 1 \mathrm{H}), 5.69(\mathrm{t}, J=5.4 \mathrm{~Hz}, 1 \mathrm{H}), 4.81(\mathrm{~d}, J=5.4 \mathrm{~Hz}$, $2 \mathrm{H}), 4.00(\mathrm{~s}, 3 \mathrm{H})$. LC-MS $(\mathrm{m} / z): 292.0\left({ }^{35} \mathrm{Cl}\right), 294.0\left({ }^{37} \mathrm{Cl}\right)[\mathrm{M}+$ $\mathrm{H}]^{+}$.

(3-(2-Chloropyrimidin-4-yl)-6-morpholinopyrazolo[1,5-b]pyridazin-2-yl)methanol (7m). (Aminooxy)sulfonic acid $(590 \mathrm{mg}$, $5.2 \mathrm{mmol}$ ) was dissolved in $5 \mathrm{~mL}$ of water, and saturated sodium bicarbonate was added to the clear solution until effervescence ceased $(\mathrm{pH} \sim 6)$. The clear colorless solution was heated to $70{ }^{\circ} \mathrm{C}$, and $4 \mathrm{a}$ (570 $\mathrm{mg}, 3.5 \mathrm{mmol}$ ) was added, and the reaction mixture was stirred at $70{ }^{\circ} \mathrm{C}$ for $2 \mathrm{~h}$. Reaction mixture was then cooled to room temperature, neutralized with saturated sodium bicarbonate (until effervescence ceased), and then a solution of $6 \mathrm{~g}(290 \mathrm{mg}, 5.2 \mathrm{mmol})$ in DCM $(15 \mathrm{~mL})$ was added followed by $\mathrm{KOH}(98 \mathrm{mg}, 1.7 \mathrm{mmol})$, and the reaction mixture was stirred for $16 \mathrm{~h}$ at room temperature. The reaction mixture was diluted with DCM and washed with water and brine, then dried over sodium sulfate, filtered, and evaporated to get the crude product which was purified by column chromatography run isocratically with $100 \%$ EtOAc, to afford the title compound as a yellow solid $(88.1 \mathrm{mg}, 15 \%) .{ }^{1} \mathrm{H}$ NMR $\left(500 \mathrm{MHz}, \mathrm{DMSO}-d_{6}\right) \delta \mathrm{ppm}$ $8.71(\mathrm{~d}, J=5.4 \mathrm{~Hz}, 1 \mathrm{H}), 8.58(\mathrm{~d}, J=9.8 \mathrm{~Hz}, 1 \mathrm{H}), 7.97(\mathrm{~d}, J=5.4$ $\mathrm{Hz}, 1 \mathrm{H}), 7.52(\mathrm{~d}, J=9.8 \mathrm{~Hz}, 1 \mathrm{H}), 5.62(\mathrm{t}, J=5.4 \mathrm{~Hz}, 1 \mathrm{H}), 4.78(\mathrm{~d}$, $J=5.4 \mathrm{~Hz}, 2 \mathrm{H}), 3.76(\mathrm{t}, J=4.9 \mathrm{~Hz}, 4 \mathrm{H}), 3.52(\mathrm{t}, J=4.9 \mathrm{~Hz}, 4 \mathrm{H})$. LC-MS $(\mathrm{m} / z): 347.1\left({ }^{35} \mathrm{Cl}\right), 349.0\left({ }^{37} \mathrm{Cl}\right)[\mathrm{M}+\mathrm{H}]^{+}$.

3 - (2-Chloropyrimidin-4-yl)-2-cyclopropyl-6methoxypyrazolo[1,5-b]pyridazine (7n). (Aminooxy)sulfonic acid $(380 \mathrm{mg}, 3.36 \mathrm{mmol}$ ) was dissolved in $4 \mathrm{~mL}$ of water, and to the clear solution saturated sodium bicarbonate was added until effervescence ceased $(\mathrm{pH} \sim 6)$. The clear colorless solution was heated to $70{ }^{\circ} \mathrm{C}$, and $\mathbf{4 b}(247 \mathrm{mg}, 2.24 \mathrm{mmol})$ was added, and the reaction mixture was stirred at $70{ }^{\circ} \mathrm{C}$ for $2 \mathrm{~h}$. The reaction mixture was then cooled to room temperature, neutralized with saturated sodium bicarbonate (until effervescence ceased), and then a solution of 2-chloro-4-(cyclopropylethynyl)pyrimidine $(200 \mathrm{mg}, 1.1 \mathrm{mmol})$ in $\mathrm{DCM}(10 \mathrm{~mL})$ was added followed by $\mathrm{KOH}(63 \mathrm{mg}, 1.1 \mathrm{mmol})$, and 
the reaction was stirred for $16 \mathrm{~h}$ at room temperature. Partial conversion to product was observed, so additional $\mathrm{KOH}(63 \mathrm{mg}, 1.1$ $\mathrm{mmol}$ ) was added, and the reaction was stirred for another $24 \mathrm{~h}$. The reaction mixture was diluted with DCM and washed with water and brine, then dried over sodium sulfate, filtered, and evaporated to get the crude product which was purified by column chromatography using EtOAc/hex 10-30\% to yield the desired compound as a white solid (99.1 mg, 29\%). ${ }^{1} \mathrm{H}$ NMR (500 MHz, DMSO- $\left.d_{6}\right) \delta$ ppm 8.73 $(\mathrm{d}, J=5.4 \mathrm{~Hz}, 1 \mathrm{H}), 8.63(\mathrm{~d}, J=9.8 \mathrm{~Hz}, 1 \mathrm{H}), 7.99(\mathrm{~d}, J=5.4 \mathrm{~Hz}, 1$ H), $7.20(\mathrm{~d}, J=9.8 \mathrm{~Hz}, 1 \mathrm{H}), 3.98(\mathrm{~s}, 3 \mathrm{H}), 2.40-2.46(\mathrm{~m}, 1 \mathrm{H})$, 1.09-1.14 (m, $2 \mathrm{H}), 1.00-1.05(\mathrm{~m}, 2 \mathrm{H})$. LC-MS $(\mathrm{m} / z): 302.1$ $\left({ }^{35} \mathrm{Cl}\right), 304.1\left({ }^{37} \mathrm{Cl}\right)[\mathrm{M}+\mathrm{H}]^{+}$.

4-(3-(2-Chloropyrimidin-4-yl)-2-cyclopropylpyrazolo[1,5-b]pyridazin-6-yl)morpholine (7o). (Aminooxy)sulfonic acid (439 $\mathrm{mg}, 3.89 \mathrm{mmol}$ ) was dissolved in $4 \mathrm{~mL}$ of water, and saturated sodium bicarbonate was added to the clear solution until effervescence ceased $(\mathrm{pH} \sim 5)$. The clear colorless solution was heated to $70{ }^{\circ} \mathrm{C}$, and $4 \mathrm{a}$ (428 mg, $2.59 \mathrm{mmol}$ ) was added, and the reaction mixture was stirred at $70{ }^{\circ} \mathrm{C}$ for $2 \mathrm{~h}$. The reaction mixture was then cooled to room temperature, neutralized with saturated sodium bicarbonate (until effervescence ceased), and then a solution of $6 \mathrm{~d}(231 \mathrm{mg}, 1.3 \mathrm{mmol})$ in DCM $(20 \mathrm{~mL})$ was added followed by $\mathrm{KOH}(73 \mathrm{mg}, 1.3 \mathrm{mmol})$, and the reaction was stirred for $16 \mathrm{~h}$ at room temperature. The reaction mixture was diluted with DCM and washed with water and brine, then dried over magnesium sulfate, filtered, and evaporated to get the crude product which was purified by column chromatography using EtOAc/hex $10-50 \%$ to provide the desired compound as a yellow solid (183.7 mg, 40\%). ${ }^{1} \mathrm{H}$ NMR (400 MHz, chloroform- $d$ ) $\delta$ ppm $8.71(\mathrm{~d}, J=9.5 \mathrm{~Hz}, 1 \mathrm{H}), 8.55(\mathrm{~d}, J=5.1 \mathrm{~Hz}, 1 \mathrm{H}), 7.84(\mathrm{~d}, J=$ $5.1 \mathrm{~Hz}, 1 \mathrm{H}), 6.98(\mathrm{~d}, J=9.5 \mathrm{~Hz}, 1 \mathrm{H}), 3.86(\mathrm{t}, J=5.1 \mathrm{~Hz}, 4 \mathrm{H}), 3.58$ $(\mathrm{t}, J=5.1 \mathrm{~Hz}, 4 \mathrm{H}), 2.13-2.23(\mathrm{~m}, 1 \mathrm{H}), 1.20-1.28(\mathrm{~m}, 2 \mathrm{H}), 1.08-$ $1.18(\mathrm{~m}, 2 \mathrm{H})$. LC-MS $(\mathrm{m} / z): 357.1\left({ }^{35} \mathrm{Cl}\right), 359.0\left({ }^{37} \mathrm{Cl}\right)[\mathrm{M}+\mathrm{H}]^{+}$.

$\mathrm{N}$-(4-Chlorobenzyl)-4-(pyrazolo[1,5-b]pyridazin-3-yl)pyrimidin-2-amine (10a). In a reaction vial 7 a $(20 \mathrm{mg}, 86 \mu \mathrm{mol})$ was stirred in $n$ - $\mathrm{BuOH}(1 \mathrm{~mL})$, and 4-chlorobenzylamine (25 mg, 170 $\mu \mathrm{mol})$ was added. The reaction mixture was stirred at $115^{\circ} \mathrm{C}$ for $16 \mathrm{~h}$. The solution changed from a red/brown color to clear yellow on heating. Upon completion of the reaction, the mixture was concentrated and taken up in DCM and washed with water and brine, then dried over sodium sulfate, decanted, and concentrated to get the crude product, which was purified by column chromatography using EtOAc/hexane $20-100 \%, 12 \mathrm{CV}$ to yield the product as a colorless solid (7 mg, 24\%). ${ }^{1} \mathrm{H}$ NMR (500 MHz, chloroform- $d$ ) $\delta$ ppm $8.46(\mathrm{~s}, 1 \mathrm{H}), 8.35(\mathrm{dd}, J=4.2,1.7 \mathrm{~Hz}, 1 \mathrm{H}), 8.31(\mathrm{~d}, J=5.4 \mathrm{~Hz}$, $1 \mathrm{H}), 7.30-7.41(\mathrm{~m}, 4 \mathrm{H}), 6.99-7.07(\mathrm{~m}, 1 \mathrm{H}), 6.94(\mathrm{~d}, J=5.4 \mathrm{~Hz}, 1$ $\mathrm{H}), 5.54-5.68(\mathrm{~m}, 1 \mathrm{H}), 4.70(\mathrm{~d}, J=5.9 \mathrm{~Hz}, 2 \mathrm{H})$. LC-MS $(\mathrm{m} / z)$ : $\left.337.0\left({ }^{35} \mathrm{Cl}\right), 339.1\left({ }^{37} \mathrm{Cl}\right)[\mathrm{M}+\mathrm{H}]\right]^{+}$.

$\mathrm{N}$-(3-Morpholinopropyl)-4-(pyrazolo[1,5-b]pyridazin-3-yl)pyrimidin-2-amine (10b). In a microwave vial containing $7 \mathbf{a}$ (30 $\mathrm{mg}, 129 \mu \mathrm{mol})$, EtOH $(1 \mathrm{~mL})$ was added followed by 3 morpholinopropan-1-amine (37 mg, $260 \mu \mathrm{mol})$, and the reaction mixture was subjected to microwave irradiation at $150{ }^{\circ} \mathrm{C}$ for $15 \mathrm{~min}$. Upon completion of the reaction, the reaction mixture was concentrated and taken up in DCM which was washed with water and brine, then dried over sodium sulfate, decanted, and concentrated to get the crude product, which was purified by column chromatography using EtOAc/MeOH $0-20 \%, 12 \mathrm{CV}$ to yield the product as a dark yellow solid (15 mg, 34\%). ${ }^{1} \mathrm{H}$ NMR $(500 \mathrm{MHz}$, chloroform- $d$ ) $\delta$ ppm $8.97(\mathrm{dd}, J=9.3,2.0 \mathrm{~Hz}, 1 \mathrm{H}), 8.45(\mathrm{~s}, 1 \mathrm{H})$, $8.37(\mathrm{dd}, J=4.4,2.0 \mathrm{~Hz}, 1 \mathrm{H}), 8.27(\mathrm{~d}, J=4.9 \mathrm{~Hz}, 1 \mathrm{H}), 7.16(\mathrm{dd}, J=$ 9.3, $4.4 \mathrm{~Hz}, 1 \mathrm{H}), 6.86(\mathrm{~d}, J=4.9 \mathrm{~Hz}, 1 \mathrm{H}), 6.01(\mathrm{br} \mathrm{s}, 1 \mathrm{H}), 3.79(\mathrm{t}, J$ $=4.2 \mathrm{~Hz}, 4 \mathrm{H}), 3.59(\mathrm{q}, J=6.3 \mathrm{~Hz}, 2 \mathrm{H}), 2.57-2.65(\mathrm{~m}, 6 \mathrm{H}), 1.91$ (quin, $J=6.4 \mathrm{~Hz}, 2 \mathrm{H}$ ). LC-MS $(\mathrm{m} / z): 340.1[\mathrm{M}+\mathrm{H}]^{+}$.

$\mathrm{N}$-Cyclopropyl-4-(6-morpholinopyrazolo[1,5-b]pyridazin-3yl)pyrimidin-2-amine (10d). In a vial $7 \mathbf{b}(15 \mathrm{mg}, 47 \mu \mathrm{mol})$ and cyclopropylamine $(1.0 \mathrm{~mL}, 14 \mathrm{mmol})$ were stirred in $1 \mathrm{~mL}$ of $n$ $\mathrm{BuOH}$. Reaction mixture was subjected to microwave irradiation at $150{ }^{\circ} \mathrm{C}$ for $1 \mathrm{~h}$. The reaction mixture was then evaporated to dryness and column purification performed using EtOAc/hex 50-100\% 12 $\mathrm{CV}$ followed by EtOAc/MeOH $1-20 \% 5 \mathrm{CV}$ to afford the title compound as a brown solid (8.9 mg, 55\%). ${ }^{1} \mathrm{H}$ NMR $(500 \mathrm{MHz}$ chloroform- $d) \delta$ ppm 8.83-8.91 $(\mathrm{m}, 1 \mathrm{H}), 8.28(\mathrm{~d}, J=4.9 \mathrm{~Hz}, 1 \mathrm{H})$, $8.23(\mathrm{~s}, 1 \mathrm{H}), 6.92(\mathrm{~d}, J=9.3 \mathrm{~Hz}, 1 \mathrm{H}), 6.90(\mathrm{~d}, J=4.9 \mathrm{~Hz}, 1 \mathrm{H}), 5.38$ $($ br s, $1 \mathrm{H}), 3.87(\mathrm{t}, J=4.9 \mathrm{~Hz}, 4 \mathrm{H}), 3.59(\mathrm{t}, J=4.9 \mathrm{~Hz}, 4 \mathrm{H}), 2.82-$ $2.87(\mathrm{~m}, 1 \mathrm{H}), 0.85-0.90(\mathrm{~m}, 2 \mathrm{H}), 0.62-0.66(\mathrm{~m}, 2 \mathrm{H})$. LC-MS $(\mathrm{m} / \mathrm{z}): 338.1[\mathrm{M}+\mathrm{H}]^{+}$.

N-Phenyl-4-(pyrazolo[1,5-b]pyridazin-3-yl)pyrimidin-2amine $(10 \mathrm{e})$. An oven-dried flask containing $7 \mathrm{a}(10 \mathrm{mg}, 43 \mu \mathrm{mol})$ in DMSO $(0.1 \mathrm{~mL})$ was heated until the solution became clear, then $n$ $\mathrm{BuOH}(0.3 \mathrm{~mL})$ and aniline $(8 \mu \mathrm{L}, 86 \mu \mathrm{mol})$ were added to the flask. The reaction mixture was heated to $120^{\circ} \mathrm{C}$ for $16 \mathrm{~h}$. After completion of reaction, the mixture was evaporated to dryness and column purification was performed using EtOAc/hex 20-100\% $15 \mathrm{CV}$ to obtain the product as an orange solid $(10 \mathrm{mg}, 80 \%) . \mathrm{Mp}=207-209$ ${ }^{\circ} \mathrm{C}$. ${ }^{1} \mathrm{H}$ NMR $(500 \mathrm{MHz}$, chloroform- $d$ ) $\delta \mathrm{ppm} 8.91$ (dd, $J=9.3,2.0$ $\mathrm{Hz}, 1 \mathrm{H}), 8.52(\mathrm{~s}, 1 \mathrm{H}), 8.43(\mathrm{~d}, J=5.4 \mathrm{~Hz}, 1 \mathrm{H}), 8.40(\mathrm{dd}, J=4.4$, $2.0 \mathrm{~Hz}, 1 \mathrm{H}), 7.61-7.65(\mathrm{~m}, 2 \mathrm{H}), 7.37-7.43(\mathrm{~m}, 2 \mathrm{H}), 7.18$ (br s, 1 H), 7.11-7.16 (m, $2 \mathrm{H}), 7.08(\mathrm{~d}, J=5.37 \mathrm{~Hz}, 1 \mathrm{H}) . \mathrm{LC}-\mathrm{MS}(\mathrm{m} / z)$ : $289.3[\mathrm{M}+\mathrm{H}]^{+}$.

$\mathrm{N}$-Phenyl-4-(2-(4-(trifluoromethyl)phenyl)pyrazolo[1,5-b]pyridazin-3-yl)pyrimidin-2-amine (10f). To an oven-dried flask containing a solution of $7 \mathrm{~d}(20 \mathrm{mg}, 53 \mu \mathrm{mol})$ in $n$-BuOH $(1 \mathrm{~mL})$, aniline $(10 \mu \mathrm{L}, 106 \mu \mathrm{mol})$ was added, and the reaction was heated to $110{ }^{\circ} \mathrm{C}$ for $16 \mathrm{~h}$. After completion of reaction, reaction mixture was evaporated to dryness and column purification was performed using EtOAc/hex, $20-100 \% 12 \mathrm{CV}$ to afford the title compound as a colorless solid (20 mg, 87\%). ${ }^{1} \mathrm{H}$ NMR (500 MHz, chloroform- $d$ ) $\delta$ ppm 8.69 (dd, $J=9.3,2.0 \mathrm{~Hz}, 1 \mathrm{H}), 8.43(\mathrm{dd}, J=4.4,2.0 \mathrm{~Hz}, 1 \mathrm{H})$, $8.26(\mathrm{~d}, J=5.4 \mathrm{~Hz}, 1 \mathrm{H}), 7.87(\mathrm{~d}, J=8.3 \mathrm{~Hz}, 2 \mathrm{H}), 7.74(\mathrm{~d}, J=8.3$ Hz, 2 H), 7.59-7.62 (m, 2 H), 7.33-7.37 (m, 2 H), 7.09-7.16 (m, 2 $\mathrm{H}), 6.60(\mathrm{~d}, J=5.4 \mathrm{~Hz}, 1 \mathrm{H})$. LC-MS $(\mathrm{m} / z): 433.1[\mathrm{M}+\mathrm{H}]^{+}$.

4-(Pyrazolo[1,5-b]pyridazin-3-yl)-N-(o-tolyl)pyrimidin-2amine $(10 \mathrm{~g})$. To an oven-dried flask containing $o$-toluidine $(19 \mu \mathrm{L}$, $173 \mu \mathrm{mol})$ and $7 \mathrm{a}(20 \mathrm{mg}, 86 \mu \mathrm{mol}), n$-BuOH was added. The reaction mixture was heated at $100{ }^{\circ} \mathrm{C}$ for $16 \mathrm{~h}$. After completion of reaction, the mixture was evaporated to dryness and column purification was performed using EtOAc/hex 20-100\% $15 \mathrm{CV}$ to yield the title compound as an off-white solid $(7 \mathrm{mg}, 27 \%) . \mathrm{Mp}=$ 177-178 ${ }^{\circ} \mathrm{C} .{ }^{1} \mathrm{H}$ NMR $(500 \mathrm{MHz}$, chloroform- $d) \delta$ ppm 8.64 (dd, $J=$ 9.3, $2.0 \mathrm{~Hz}, 1 \mathrm{H}), 8.49(\mathrm{~s}, 1 \mathrm{H}), 8.40(\mathrm{~d}, J=5.4 \mathrm{~Hz}, 1 \mathrm{H}), 8.35$ (dd, $J$ $=4.4,2.0 \mathrm{~Hz}, 1 \mathrm{H}), 7.82(\mathrm{~d}, J=7.8 \mathrm{~Hz}, 1 \mathrm{H}), 7.28-7.32(\mathrm{~m}, 2 \mathrm{H})$, $7.16(\mathrm{td}, J=7.3,1.5 \mathrm{~Hz}, 1 \mathrm{H}), 7.01-7.05(\mathrm{~m}, 2 \mathrm{H}), 6.86(\mathrm{br} \mathrm{s}, 1 \mathrm{H})$, $2.36(\mathrm{~s}, 3 \mathrm{H})$. LC-MS $(\mathrm{m} / z): 303.3[\mathrm{M}+\mathrm{H}]^{+}$.

$\mathrm{N}$-(3-Nitrophenyl)-4-(pyrazolo[1,5-b]pyridazin-3-yl)pyrimidin-2-amine (10h). In a vial $7 \mathrm{a}(50 \mathrm{mg}, 216 \mu \mathrm{mol})$ and 3 nitroaniline $(52 \mathrm{mg}, 540 \mu \mathrm{mol})$ were stirred in $n-\mathrm{BuOH}(1.5 \mathrm{~mL})$, and the reaction mixture was subjected to microwave irradiation at $150{ }^{\circ} \mathrm{C}$ for $2 \mathrm{~h}$. After completion of reaction, the mixture was filtered and washed with $\mathrm{MeOH}$. The precipitate was purified using column chromatography using EtOAc/hex, 50-100\%, to yield the title compound as a yellow solid (52 mg, 72\%). ${ }^{1} \mathrm{H}$ NMR $(500 \mathrm{MHz}$, DMSO- $\left.d_{6}\right) \delta$ ppm $10.14(\mathrm{~s}, 1 \mathrm{H}), 9.15-9.21(\mathrm{~m}, 1 \mathrm{H}), 8.98(\mathrm{~s}, 1 \mathrm{H})$, $8.92(\mathrm{t}, J=2.4 \mathrm{~Hz}, 1 \mathrm{H}), 8.66(\mathrm{dd}, J=4.4,2.0 \mathrm{~Hz}, 1 \mathrm{H}), 8.59(\mathrm{~d}, J=$ $5.4 \mathrm{~Hz}, 1 \mathrm{H}), 8.11(\mathrm{dd}, J=8.3,2.0 \mathrm{~Hz}, 1 \mathrm{H}), 7.84(\mathrm{dd}, J=8.3,2.0 \mathrm{~Hz}$, $1 \mathrm{H}), 7.64(\mathrm{t}, J=8.3 \mathrm{~Hz}, 1 \mathrm{H}), 7.53(\mathrm{~d}, J=5.4 \mathrm{~Hz}, 1 \mathrm{H}), 7.49(\mathrm{dd}, J=$ $8.8,4.4 \mathrm{~Hz}, 1 \mathrm{H})$. LC-MS $(\mathrm{m} / z): 334.0[\mathrm{M}+\mathrm{H}]^{+}$.

$N$-(3-Methoxyphenyl)-4-(pyrazolo[1,5-b]pyridazin-3-yl)pyrimidin-2-amine (10i). To an oven-dried flask containing 3methoxyaniline $(22 \mu \mathrm{L}, 194 \mu \mathrm{mol})$, a solution of $7 \mathrm{a}(30 \mathrm{mg}, 130$ $\mu \mathrm{mol})$ and acetic acid $(1 \mathrm{~mL})$ in dioxane $(2 \mathrm{~mL})$ was added. The reaction mixture was stirred at $110{ }^{\circ} \mathrm{C}$ for $23 \mathrm{~h}$ and monitored by TLC. The reaction mixture appeared dark red/brown, and some solid particles were observed. Upon completion, the mixture was extracted with DCM $(3 \times 100 \mathrm{~mL})$. The combined organic phase was washed with brine and dried over sodium sulfate. Column purification was performed by preparative reverse phase HPLC using 5-100\% ACN/ water system to afford the pure product as white solid $(15 \mathrm{mg}, 36 \%)$. ${ }^{1} \mathrm{H}$ NMR (500 MHz, DMSO- $\left.d_{6}\right) \delta$ ppm $9.57(\mathrm{~s}, 1 \mathrm{H}), 9.17-9.24(\mathrm{~m}$, $1 \mathrm{H}), 8.90(\mathrm{~s}, 1 \mathrm{H}), 8.62(\mathrm{dd}, J=4.4,2.0 \mathrm{~Hz}, 1 \mathrm{H}), 8.49(\mathrm{~d}, J=5.4$ $\mathrm{Hz}, 1 \mathrm{H}), 7.43-7.49(\mathrm{~m}, 2 \mathrm{H}), 7.39(\mathrm{~d}, J=5.4 \mathrm{~Hz}, 1 \mathrm{H}), 7.33$ (d, $J=$ 
$8.3 \mathrm{~Hz}, 1 \mathrm{H}), 7.23(\mathrm{t}, J=8.3 \mathrm{~Hz}, 1 \mathrm{H}), 6.58(\mathrm{dd}, J=7.8,2.4 \mathrm{~Hz}, 1 \mathrm{H})$, $3.76(\mathrm{~s}, 3 \mathrm{H})$. LC-MS $(\mathrm{m} / z): 319.0[\mathrm{M}+\mathrm{H}]^{+}$.

4-(2-Cyclopropylpyrazolo[ $1,5-b]$ pyridazin-3-yl)- $\mathrm{N}-(3,4-$ difluorophenyl)pyrimidin-2-amine (10n). In a vial, $7 \mathrm{e}(30 \mathrm{mg}$, $110 \mu \mathrm{mol})$ and 3,4-difluoroaniline $(21 \mathrm{mg}, 170 \mu \mathrm{mol})$ were dissolved in $n$ - $\mathrm{BuOH}(1.5 \mathrm{~mL})$. The vial was sealed, and the reaction was subjected to microwave irradiation at $150{ }^{\circ} \mathrm{C}$ for $2 \mathrm{~h}$. The reaction was cooled to room temperature, then filtered and washed with diethyl ether. The precipitate was taken up in DCM and washed with saturated sodium bicarbonate. The organic layer was dried over sodium sulfate, filtered, and evaporated in vacuo to yield the product (22 mg, 55\%). ${ }^{1} \mathrm{H}$ NMR (400 MHz, chloroform- $d$ ) $\delta$ ppm 8.66 (dd, $J$ $=8.8,1.5 \mathrm{~Hz}, 1 \mathrm{H}), 8.48(\mathrm{~d}, J=5.1 \mathrm{~Hz}, 1 \mathrm{H}), 8.32(\mathrm{dd}, J=4.4,1.5$ $\mathrm{Hz}, 1 \mathrm{H}), 7.86(\mathrm{dd}, J=8.1,2.2 \mathrm{~Hz}, 1 \mathrm{H}), 7.36(\mathrm{~d}, J=5.1 \mathrm{~Hz}, 1 \mathrm{H})$, $7.09-7.15(\mathrm{~m}, 3 \mathrm{H}), 2.32-2.42(\mathrm{~m}, 1 \mathrm{H}), 1.29-1.35(\mathrm{~m}, 2 \mathrm{H}), 1.13-$ $1.21(\mathrm{~m}, 2 \mathrm{H})$. LC-MS $(\mathrm{m} / \mathrm{z}): 365.0[\mathrm{M}+\mathrm{H}]^{+}$.

$\mathrm{N}$-(4-(tert-Butyl)phenyl)-4-(pyrazolo[1,5-b]pyridazin-3-yl)pyrimidin-2-amine (10s). To an oven-dried flask was added 4tertbutylaniline $(28 \mu \mathrm{L}, 173 \mu \mathrm{mol})$ to a solution of $7 \mathrm{a}(20 \mathrm{mg}, 86$ $\mu \mathrm{mol})$ in $n-\mathrm{BuOH}$. The reaction mixture was heated to $100{ }^{\circ} \mathrm{C}$ for 16 h. After completion of reaction, the mixture was evaporated to dryness and column purification was performed using EtOAc/hex 20-100\% $15 \mathrm{CV}$ to afford the title compound as a yellow solid (16 mg, 53\%). ${ }^{1} \mathrm{H}$ NMR (500 MHz, chloroform- $d$ ) $\delta$ ppm 8.83 (dd, $J=8.8,2.0 \mathrm{~Hz}, 1$ $\mathrm{H}), 8.51(\mathrm{~s}, 1 \mathrm{H}), 8.39(\mathrm{dd}, J=4.4,2.0 \mathrm{~Hz}, 1 \mathrm{H}), 8.36(\mathrm{~d}, J=5.4 \mathrm{~Hz}$, $1 \mathrm{H}), 7.70$ (br s, $1 \mathrm{H}), 7.49-7.54(\mathrm{~m}, 2 \mathrm{H}), 7.40-7.45$ (m, $2 \mathrm{H}), 7.09$ $(\mathrm{dd}, J=8.8,4.4 \mathrm{~Hz}, 1 \mathrm{H}), 7.05(\mathrm{~d}, J=5.4 \mathrm{~Hz}, 1 \mathrm{H}), 1.37(\mathrm{~s}, 9 \mathrm{H})$. LC-MS $(m / z): 345.4[\mathrm{M}+\mathrm{H}]^{+}$.

3-(2-Chloropyrimidin-4-yl)pyrazolo[1,5-a]pyridine (11). (Aminooxy)sulfonic acid $(490 \mathrm{mg}, 4.33 \mathrm{mmol}$ ) was dissolved in 2 $\mathrm{mL}$ of water, and to the clear solution was added $2.5 \mathrm{M}$ sodium bicarbonate until effervescence ceased $(\mathrm{pH} \sim 5)$. The clear colorless solution was heated to $70{ }^{\circ} \mathrm{C}$, and pyridine $(0.233 \mathrm{~mL}, 2.89 \mathrm{mmol})$ was added, and the reaction mixture was stirred at $70{ }^{\circ} \mathrm{C}$ for $2 \mathrm{~h}$. The reaction was cooled to room temperature, neutralized with $2.5 \mathrm{M}$ sodium bicarbonate (until effervescence ceased), and then solution of 6b $(185 \mathrm{mg}, 1.34 \mathrm{mmol})$ in DCM $(10 \mathrm{~mL})$ was added followed by $\mathrm{KOH}(100 \mathrm{mg}, 1.78 \mathrm{mmol})$. The reaction was stirred for $16 \mathrm{~h}$ at room temperature. The reaction mixture was then diluted with DCM and washed with water and brine, then dried over sodium sulfate, decanted, and concentrated to get the crude product, which was purified by column chromatography using EtOAc/hex, 50-100\% 12 $\mathrm{CV}$, followed by EtOAc/MeOH $0-20 \% 5 \mathrm{CV}$ to obtain the desired compound as a beige solid $(85 \mathrm{mg}, 51 \%) .{ }^{1} \mathrm{H}$ NMR $(500 \mathrm{MHz}$, DMSO- $\left.d_{6}\right) \delta$ ppm $8.95(\mathrm{~s}, 1 \mathrm{H}), 8.90(\mathrm{~d}, J=6.8 \mathrm{~Hz}, 1 \mathrm{H}), 8.62(\mathrm{~d}, J=$ $5.4 \mathrm{~Hz}, 1 \mathrm{H}), 8.49(\mathrm{~d}, J=8.8 \mathrm{~Hz}, 1 \mathrm{H}), 7.97(\mathrm{~d}, J=5.4 \mathrm{~Hz}, 1 \mathrm{H})$, $7.62-7.68(\mathrm{~m}, 1 \mathrm{H}), 7.19(\mathrm{td}, J=6.8,1.5 \mathrm{~Hz}, 1 \mathrm{H})$. LC-MS $(\mathrm{m} / z)$ : $230.9\left({ }^{35} \mathrm{Cl}\right), 232.9\left({ }^{37} \mathrm{Cl}\right)[\mathrm{M}+\mathrm{H}]^{+}$.

N-Cyclopropyl-4-(pyrazolo[1,5-a]pyridin-3-yl)pyrimidin-2amine (12a). In a vial $11(10 \mathrm{mg}, 43 \mu \mathrm{mol})$, cyclopropylamine $(6 \mu \mathrm{L}$, $87 \mu \mathrm{mol})$, and DIPEA $(16 \mu \mathrm{L}, 87 \mu \mathrm{mol})$ were stirred in $n-\mathrm{BuOH}$ and subjected to microwave irradiation at $150{ }^{\circ} \mathrm{C}$ for $1 \mathrm{~h}$. The reaction mixture was evaporated to dryness and purified by column chromatography using EtOAc/hex, 40-100\%, $7 \mathrm{CV}$, followed by $\mathrm{MeOH} / \mathrm{EtOAc}, 0-20 \% 5 \mathrm{CV}$ to yield the title compound as a colorless solid (8 mg, 66\%). ${ }^{1} \mathrm{H}$ NMR (500 MHz, chloroform- $d$ ) $\delta$ ppm 8.69-8.79 (m, $1 \mathrm{H}), 8.52(\mathrm{~d}, J=6.8 \mathrm{~Hz}, 1 \mathrm{H}), 8.42(\mathrm{~s}, 1 \mathrm{H})$, $8.28(\mathrm{~d}, J=4.9 \mathrm{~Hz}, 1 \mathrm{H}), 7.33$ (ddd, $J=8.8,6.8,1.0 \mathrm{~Hz}, 1 \mathrm{H}), 6.87-$ $6.95(\mathrm{~m}, 2 \mathrm{H}), 2.82-2.92(\mathrm{~m}, 1 \mathrm{H}), 0.84-0.93(\mathrm{~m}, 2 \mathrm{H}), 0.60-0.68$ $(\mathrm{m}, 2 \mathrm{H})$. LC-MS $(\mathrm{m} / \mathrm{z}): 252.0[\mathrm{M}+\mathrm{H}]^{+}$.

$N$-Phenyl-4-(pyrazolo[1,5-a]pyridin-3-yl)pyrimidin-2-amine (12b). In a vial were added $11(10 \mathrm{mg}, 43 \mu \mathrm{mol})$ and aniline $(8 \mu \mathrm{L}$, $87 \mathrm{mmol}$ ), and the mixture was stirred in $n-\mathrm{BuOH}$ at $110^{\circ} \mathrm{C}$ for $16 \mathrm{~h}$. The reaction mixture was evaporated to dryness and purified by column chromatography using EtOAc/hex, 40-100\% $12 \mathrm{CV}$ followed by $\mathrm{EtOAc} / \mathrm{MeOH} 1-20 \% 5 \mathrm{CV}$ to afford the title compound as a beige solid (11 mg, 88\%). ${ }^{1} \mathrm{H}$ NMR $(500 \mathrm{MHz}$, chloroform- $d) \delta \mathrm{ppm}$ $8.51-8.57(\mathrm{~m}, 2 \mathrm{H}), 8.46(\mathrm{~s}, 1 \mathrm{H}), 8.35-8.40(\mathrm{~m}, 1 \mathrm{H}), 7.67(\mathrm{~d}, J=$ $7.3 \mathrm{~Hz}, 2 \mathrm{H}), 7.36-7.41(\mathrm{~m}, 2 \mathrm{H}), 7.28-7.35(\mathrm{~m}, 2 \mathrm{H}), 7.10(\mathrm{t}, J=$
$7.3 \mathrm{~Hz}, 1 \mathrm{H}), 7.04(\mathrm{~d}, J=5.4 \mathrm{~Hz}, 1 \mathrm{H}), 6.89-6.95(\mathrm{~m}, 1 \mathrm{H}) . \mathrm{LC}-\mathrm{MS}$ $(\mathrm{m} / z): 288.0[\mathrm{M}+\mathrm{H}]^{+}$.

$\mathrm{N}$-(3-Methoxyphenyl)-4-(pyrazolo[1,5-a]pyridin-3-yl)pyrimidin-2-amine (12c). In a vial $11(20 \mathrm{mg}, 87 \mu \mathrm{mol})$ and 3anisidine $(20 \mu \mathrm{L}, 0.173 \mathrm{mmol})$ were stirred in $n-\mathrm{BuOH}$ at $110^{\circ} \mathrm{C}$ for $16 \mathrm{~h}$. The reaction mixture was then evaporated to dryness and column purification was performed using EtOAc/hex 40-100\% 12 $\mathrm{CV}$ followed by EtOAc/MeOH $1-20 \% 5 \mathrm{CV}$ to afford the title compound as a beige solid (11 mg, 40\%). ${ }^{1} \mathrm{H}$ NMR $(500 \mathrm{MHz}$, DMSO- $\left.d_{6}\right) \delta$ ppm $9.49(\mathrm{~s}, 1 \mathrm{H}), 8.81-8.86(\mathrm{~m}, 2 \mathrm{H}), 8.77(\mathrm{~d}, J=8.8$ $\mathrm{Hz}, 1 \mathrm{H}), 8.41(\mathrm{~d}, J=5.4 \mathrm{~Hz}, 1 \mathrm{H}), 7.46-7.52(\mathrm{~m}, 2 \mathrm{H}), 7.30-7.37$ $(\mathrm{m}, 2 \mathrm{H}), 7.22(\mathrm{t}, J=8.1 \mathrm{~Hz}, 1 \mathrm{H}), 7.11(\mathrm{t}, J=6.8 \mathrm{~Hz}, 1 \mathrm{H}), 6.57(\mathrm{dd}$, $J=8.3,2.2 \mathrm{~Hz}, 1 \mathrm{H}), 3.76(\mathrm{~s}, 3 \mathrm{H})$. LC-MS $(\mathrm{m} / z): 318.0[\mathrm{M}+\mathrm{H}]^{+}$.

3-((4-(Pyrazolo[1,5-a]pyridin-3-yl)pyrimidin-2-yl)amino)benzonitrile (12d). In a vial $11(20 \mathrm{mg}, 87 \mu \mathrm{mol}), \mathrm{K}_{3} \mathrm{PO}_{4}(37 \mathrm{mg}$, $173 \mu \mathrm{mol})$, XPhos (6 mg, $13 \mu \mathrm{mol})$, tris(dibenzylideneacetone)palladium(0) (4.0 mg, $4.3 \mu \mathrm{mol})$, and 3-aminobenzonitrile $(20.5 \mathrm{mg}$, $173 \mu \mathrm{mol}$ ) were added. The vial was evacuated, then backfilled with $\mathrm{N}_{2}$ three times. Degassed anhydrous toluene $(1 \mathrm{~mL})$ was added to a sealed vial. The reaction mixture was degassed for another $5 \mathrm{~min}$ and left stirring at $110{ }^{\circ} \mathrm{C}$ for $16 \mathrm{~h}$. The heterogeneous red reaction mixture slowly turned yellow and clear with some floating particles. The reaction mixture was evaporated to dryness and purified by using preparative reverse phase HPLC to afford the title compound as a pale-yellow solid (6 mg, 22\%). ${ }^{1} \mathrm{H}$ NMR (500 MHz, chloroform- $d$ ) $\delta$ ppm $9.19(\mathrm{~s}, 1 \mathrm{H}), 8.86(\mathrm{~d}, J=7.0 \mathrm{~Hz}, 1 \mathrm{H}), 8.85(\mathrm{~s}, 1 \mathrm{H}), 8.71(\mathrm{~d}, J$ $=9.0 \mathrm{~Hz}, 1 \mathrm{H}), 8.53(\mathrm{~s}, 1 \mathrm{H}), 8.48(\mathrm{~d}, J=5.0 \mathrm{~Hz}, 1 \mathrm{H}), 8.43(\mathrm{t}, J=$ $2.0 \mathrm{~Hz}, 1 \mathrm{H}), 7.96(\mathrm{dt}, J=8.0,1.5 \mathrm{~Hz}, 1 \mathrm{H}), 7.56-7.52(\mathrm{~m}, 2 \mathrm{H})$, 7.42-7.41 (m, $2 \mathrm{H}), 7.13$ (td, $J=7.0,1.5 \mathrm{~Hz}, 1 \mathrm{H})$. LC-MS $(\mathrm{m} / z)$ : $313.0[\mathrm{M}+\mathrm{H}]^{+}$.

Methyl Pyrazolo[1,5-b]pyridazine-3-carboxylate (14a). (Aminooxy)sulfonic acid $(8.1 \mathrm{~g}, 71 \mathrm{mmol}$ ) was dissolved in $13 \mathrm{~mL}$ of water, and to the clear colorless solution was added saturated sodium bicarbonate until effervescence ceased $(\mathrm{pH} \sim 6)$. The clear colorless solution was heated to $70{ }^{\circ} \mathrm{C}$, and pyridazine $(3.4 \mathrm{~mL}, 48$ $\mathrm{mmol}$ ) was added dropwise, and the reaction was stirred at $70^{\circ} \mathrm{C}$ for $2 \mathrm{~h}$. The reaction was cooled to room temperature, neutralized with sat. sodium bicarbonate (until effervescence ceased), and then a solution of $13(1.1 \mathrm{~mL}, 12 \mathrm{mmol})$ in DCM $(50 \mathrm{~mL})$ was added followed by $\mathrm{KOH}(1.3 \mathrm{~g}, 24 \mathrm{mmol})$. The reaction was stirred for $16 \mathrm{~h}$ at room temperature. After completion of reaction, the reaction mixture was diluted with DCM, washed with water, brine, and dried over magnesium sulfate, filtered, and evaporated to obtain the desired compound as a $\tan$ solid (1.5 g, 71\%). ${ }^{1} \mathrm{H}$ NMR $(500 \mathrm{MHz}$, chloroform- $d$ ) $\delta \mathrm{ppm} 8.56(\mathrm{dd}, J=9.0,1.7 \mathrm{~Hz}, 1 \mathrm{H}), 8.49(\mathrm{~s}, 1 \mathrm{H})$, $8.44(\mathrm{dd}, J=4.2,1.7 \mathrm{~Hz}, 1 \mathrm{H}), 7.25-7.29(\mathrm{~m}, 1 \mathrm{H}), 3.94(\mathrm{~s}, 3 \mathrm{H})$. LC-MS $(m / z): 177.9[\mathrm{M}+\mathrm{H}]^{+}$.

Pyrazolo[1,5-b]pyridazine-3-carboxylic Acid Hydrochloride (14b). In a round-bottom flask $14 \mathrm{a}(1.0 \mathrm{~g}, 5.6 \mathrm{mmol})$ was dissolved in water $(15 \mathrm{~mL})$, sodium hydroxide $(677 \mathrm{mg}, 16.9 \mathrm{mmol})$ was added, and the reaction was heated to $70{ }^{\circ} \mathrm{C}$ for $1 \mathrm{~h}$. The reaction was cooled to room temperature, and $1 \mathrm{M} \mathrm{HCl}$ was added, which caused a precipitate to form. The precipitate was filtered to yield the desired product as a white solid (414 mg, 37\%). ${ }^{1} \mathrm{H}$ NMR (500 MHz, DMSO- $\left.d_{6}\right) \delta$ ppm $8.62(\mathrm{dd}, J=4.4,2.0 \mathrm{~Hz}, 1 \mathrm{H}), 8.52(\mathrm{dd}, J=9.3$, $2.0 \mathrm{~Hz}, 1 \mathrm{H}), 8.47(\mathrm{~s}, 1 \mathrm{H}), 7.48(\mathrm{dd}, J=9.3,4.4 \mathrm{~Hz}, 1 \mathrm{H})$. LC-MS $(\mathrm{m} / \mathrm{z}): 163.8[\mathrm{M}+\mathrm{H}]^{+}$.

3-Bromopyrazolo[1,5-bpyridazine (15). In a round-bottom flask 14b (410 mg, $2.1 \mathrm{mmol})$ was dissolved in anhydrous DMF (10 $\mathrm{mL}), \mathrm{N}$-bromosuccinimide $(520 \mathrm{mg}, 2.9 \mathrm{mmol})$ was added, and the reaction was stirred at room temperature for $3 \mathrm{~h}$. The reaction was poured into water and extracted with EtOAc, then the organic layer was washed three times with $1 \mathrm{M} \mathrm{LiCl}$, followed by brine, then dried over magnesium sulfate, filtered, and evaporated in vacuo to yield the compound as a white solid (327 mg, 80\%). ${ }^{1} \mathrm{H}$ NMR (500 MHz, DMSO- $\left.d_{6}\right) \delta \mathrm{ppm} 8.51(\mathrm{dd}, J=4.4,2.0 \mathrm{~Hz}, 1 \mathrm{H}), 8.27(\mathrm{~s}, 1 \mathrm{H}), 8.19$ (dd, $J=8.8,2.0 \mathrm{~Hz}, 1 \mathrm{H}), 7.30(\mathrm{dd}, J=8.8,4.4 \mathrm{~Hz}, 1 \mathrm{H})$. LC-MS $(\mathrm{m} / z): 197.8\left({ }^{79} \mathrm{Br}\right), 199.8\left({ }^{81} \mathrm{Br}\right)[\mathrm{M}+\mathrm{H}]^{+}$.

3-Phenylpyrazolo[1,5-b]pyridazine (16a). In a vial 15 (42.1 $\mathrm{mg}, 213 \mu \mathrm{mol}$ ) was added to $1.5 \mathrm{~mL}$ of $3: 1$ mixture of degassed 
dioxane/water, $0.25 \mathrm{~mL}$ of DCM was added followed by phenyl boronic acid $(31.1 \mathrm{mg}, 255 \mu \mathrm{mol}), \mathrm{Pd}(\mathrm{dppf})_{2} \mathrm{Cl}_{2}(9 \mathrm{mg}, 11 \mu \mathrm{mol})$, and potassium carbonate $(88 \mathrm{mg}, 628 \mu \mathrm{mol})$. The reaction mixture was subjected to microwave irradiation and heated to $130{ }^{\circ} \mathrm{C}$ for $1 \mathrm{~h}$. The reaction was diluted with DCM and water and extracted 3 times into DCM, washed with brine, dried over magnesium sulfate, filtered, and evaporated in vacuo. Column purification was performed using EtOAc/hex $0-50 \%$ to afford the product as a white solid $(6.2 \mathrm{mg}$, $15 \%) .{ }^{1} \mathrm{H}$ NMR $(500 \mathrm{MHz}$, chloroform- $d$ ) $\delta$ ppm 8.31 (dd, $J=4.4$, $2.0 \mathrm{~Hz}, 1 \mathrm{H}), 8.24(\mathrm{~s}, 1 \mathrm{H}), 8.21(\mathrm{dd}, J=8.8,2.0 \mathrm{~Hz}, 1 \mathrm{H}), 7.56-7.60$ $(\mathrm{m}, 2 \mathrm{H}), 7.47-7.51(\mathrm{~m}, 2 \mathrm{H}), 7.34-7.38(\mathrm{~m}, 1 \mathrm{H}), 7.05(\mathrm{dd}, J=8.8$, $4.4 \mathrm{~Hz}, 1 \mathrm{H})$. LC-MS $(\mathrm{m} / z): 196.0[\mathrm{M}+\mathrm{H}]^{+}$.

3-(3-Chlorophenyl)pyrazolo[1,5-b]pyridazine (16b). In a sealed vial $15(100 \mathrm{mg}, 505 \mu \mathrm{mol}), 28(103 \mathrm{mg}, 656 \mu \mathrm{mol})$, potassium acetate $(209 \mathrm{mg}, 1.51 \mathrm{mmol})$, and $\mathrm{PdCl}_{2}(\mathrm{dppf}) \cdot \mathrm{CH}_{2} \mathrm{Cl}_{2}$ $(21 \mathrm{mg}, 25 \mathrm{mmol})$ were stirred in $4 \mathrm{~mL}$ of 3:1 mixture of degassed dioxane/water. The reaction was evacuated and backfilled with $\mathrm{N}_{2}$ three times, then subjected to microwave irradiation at $130{ }^{\circ} \mathrm{C}$ for $1 \mathrm{~h}$. The reaction was cooled and filtered through Celite and washed with EtOAc, then concentrated in vacuo. Column purification was performed using EtOAc/hex 25-50\% to yield the desired compound as a yellow solid ( $83 \mathrm{mg}, 72 \%) .{ }^{1} \mathrm{H}$ NMR $(500 \mathrm{MHz}$, chloroform- $d$ ) $\delta$ ppm 8.34 (dd, $J=4.4,2.0 \mathrm{~Hz}, 1 \mathrm{H}), 8.23(\mathrm{~s}, 1 \mathrm{H}), 8.19$ (dd, $J=9.3$, $2.0 \mathrm{~Hz}, 1 \mathrm{H}), 7.55-7.57(\mathrm{~m}, 1 \mathrm{H}), 7.44-7.48(\mathrm{~m}, 1 \mathrm{H}), 7.41(\mathrm{t}, J=$ $7.8 \mathrm{~Hz}, 1 \mathrm{H}), 7.31-7.35(\mathrm{~m}, 1 \mathrm{H}), 7.09(\mathrm{dd}, J=9.3,4.4 \mathrm{~Hz}, 1 \mathrm{H})$. LC-MS $(\mathrm{m} / z): 230.2\left({ }^{35} \mathrm{Cl}\right), 232.0\left({ }^{37} \mathrm{Cl}\right)[\mathrm{M}+\mathrm{H}]^{+}$.

3-((3-(Pyrazolo[1,5-b]pyridazin-3-yl)phenyl)amino)benzonitrile (17). In a sealed vial $16 \mathrm{~b}, 3$-aminobenzonitrile $(51 \mathrm{mg}$, $435 \mu \mathrm{mol})$, cesium carbonate $(212 \mathrm{mg}, 653 \mu \mathrm{mol})$, palladium(II) acetate $(2.4 \mathrm{mg}, 10.9 \mu \mathrm{mol})$, and Xantphos $(12.6 \mathrm{mg}, 21.7 \mu \mathrm{mol})$ were stirred in anhydrous dioxane $(2 \mathrm{~mL})$, and the reaction mixture was evacuated and backfilled with $\mathrm{N}_{2}$ three times. The reaction mixture was then subjected to microwave irradiation at $160{ }^{\circ} \mathrm{C}$ for 1 h. The reaction was filtered through Celite and washed with EtOAc, then evaporated to dryness. Column purification was performed using EtOAc/hex $20-50 \%$, to afford the title compound as a yellow solid (31.9 mg, 47\%). ${ }^{1} \mathrm{H}$ NMR (500 MHz, chloroform- $d$ ) $\delta$ ppm 8.32 (dd, $J=4.4,2.0 \mathrm{~Hz}, 1 \mathrm{H}), 8.21(\mathrm{~s}, 1 \mathrm{H}), 8.18(\mathrm{dd}, J=8.8,2.0 \mathrm{~Hz}, 1 \mathrm{H})$, $7.43(\mathrm{t}, J=7.8 \mathrm{~Hz}, 1 \mathrm{H}), 7.33-7.38(\mathrm{~m}, 2 \mathrm{H}), 7.27-7.29(\mathrm{~m}, 2 \mathrm{H})$, 7.24-7.25 (m, $1 \mathrm{H}), 7.17-7.21(\mathrm{~m}, 1 \mathrm{H}), 7.10(\mathrm{dd}, J=7.8,2.0 \mathrm{~Hz}, 1$ H), 7.07 (dd, $J=8.8,4.4 \mathrm{~Hz}, 1 \mathrm{H}), 5.94(\mathrm{br} \mathrm{s}, 1 \mathrm{H})$. LC-MS $(\mathrm{m} / z)$ : $312.1[\mathrm{M}+\mathrm{H}]^{+}$.

3-(Pyridin-2-yl)pyrazolo[1,5-b]pyridazine (18a). In a vial, (aminooxy)sulfonic acid $(658 \mathrm{mg}, 5.82 \mathrm{mmol}$ ) was dissolved in 1 $\mathrm{mL}$ of water, and to the clear colorless solution saturated sodium bicarbonate was added until effervescence ceased $(\mathrm{pH} \sim 6)$. The clear colorless solution was heated to $70{ }^{\circ} \mathrm{C}$, and pyridazine $(0.280 \mathrm{~mL}$, $3.88 \mathrm{mmol}$ ) was added dropwise, and the reaction was stirred at 70 ${ }^{\circ} \mathrm{C}$ for $2 \mathrm{~h}$. Reaction mixture then cooled to room temperature, neutralized with saturated sodium bicarbonate (until effervescence ceased), and then a solution of 2-ethynylpyridine (100 mg, 0.716 $\mu \mathrm{mol})$ in DCM $(8 \mathrm{~mL})$ was added followed by 1,8 diazabicyclo[5.4.0] undec-7-ene $(0.145 \mathrm{~mL}, 970 \mu \mathrm{mol})$. The reaction mixture was subjected to microwave irradiation at $100{ }^{\circ} \mathrm{C}$ for $30 \mathrm{~min}$, then $120^{\circ} \mathrm{C}$ for $30 \mathrm{~min}$. The reaction was then left stirring at $40{ }^{\circ} \mathrm{C}$ for $72 \mathrm{~h}$ After completion, the reaction mixture was extracted in DCM, washed with water, brine, and dried over sodium sulfate, filtered, and evaporated to get the crude product. Column purification was performed using EtOAc/hex 20-50\%, followed by a second column purification using $\mathrm{MeOH} / \mathrm{DCM} 0-5 \%$ to afford the title compound as an orange solid $(7.1 \mathrm{mg}, 4 \%) .{ }^{1} \mathrm{H}$ NMR $(500 \mathrm{MHz}$, chloroform- $d$ ) $\delta$ ppm 9.03 (dd, $J=9.3,2.0 \mathrm{~Hz}, 1 \mathrm{H}), 8.65-8.69(\mathrm{~m}, 1$ $\mathrm{H}), 8.47(\mathrm{~s}, 1 \mathrm{H}), 8.37(\mathrm{dd}, J=4.4,2.0 \mathrm{~Hz}, 1 \mathrm{H}), 7.76(\mathrm{td}, J=7.3,2.0$ $\mathrm{Hz}, 1 \mathrm{H}), 7.68-7.72(\mathrm{~m}, 1 \mathrm{H}), 7.18$ (ddd, $J=7.3,4.9,1.0 \mathrm{~Hz}, 1 \mathrm{H})$, 7.15 (dd, $J=9.3,4.4 \mathrm{~Hz}, 1 \mathrm{H})$. LC-MS $(m / z): 196.9[\mathrm{M}+\mathrm{H}]^{+}$.

3-((6-(Pyrazolo[1,5-b]pyridazin-3-yl)pyridin-2-yl)amino)benzonitrile (18b). In a sealed vial $29(27.5 \mathrm{mg}, 119 \mu \mathrm{mol})$, cesium carbonate $(117 \mathrm{mg}, 358 \mu \mathrm{mol}), 3$-aminobenzonitrile $(28 \mathrm{mg}, 238$ $\mu \mathrm{mol})$, palladium(II) acetate $(1.3 \mathrm{mg}, 6.0 \mu \mathrm{mol})$, and Xantphos (6.9 $\mathrm{mg}, 11.9 \mu \mathrm{mol})$ were stirred in anhydrous dioxane $(1.5 \mathrm{~mL})$, the reaction mixture was evacuated and backfilled with $\mathrm{N}_{2}$ three times. The reaction mixture was then subjected to MW irradiation at $160{ }^{\circ} \mathrm{C}$ for $1 \mathrm{~h}$. The reaction was filtered through Celite and washed with EtOAc, then evaporated to dryness. Column purification was performed using EtOAc/hex $20-50 \%$ to afford the product as a yellow solid (16.0 mg, 43\%). ${ }^{1} \mathrm{H}$ NMR (500 MHz, chloroform- $d$ ) $\delta$ ppm 8.84 (dd, $J=9.3,2.0 \mathrm{~Hz}, 1 \mathrm{H}), 8.45(\mathrm{~s}, 1 \mathrm{H}), 8.36$ (dd, $J=4.4$, $2.0 \mathrm{~Hz}, 1 \mathrm{H}), 8.09(\mathrm{~s}, 1 \mathrm{H}), 7.65(\mathrm{t}, J=7.8 \mathrm{~Hz}, 1 \mathrm{H}), 7.52-7.57(\mathrm{~m}, 1$ $\mathrm{H}), 7.44(\mathrm{t}, J=7.8 \mathrm{~Hz}, 1 \mathrm{H}), 7.32-7.36(\mathrm{~m}, 1 \mathrm{H}), 7.15(\mathrm{dd}, J=9.3$, $4.4 \mathrm{~Hz}, 1 \mathrm{H}), 6.66(\mathrm{~d}, J=7.8 \mathrm{~Hz}, 1 \mathrm{H}), 6.54-6.60(\mathrm{~m}, 1 \mathrm{H}) . \mathrm{LC}-\mathrm{MS}$ $(\mathrm{m} / z): 313.1[\mathrm{M}+\mathrm{H}]^{+}$.

3-(Pyridin-4-yl)pyrazolo[1,5-b]pyridazine (18c). (Aminooxy)sulfonic acid ( $486 \mathrm{mg}, 4.30 \mathrm{mmol}$ ) was dissolved in $2 \mathrm{~mL}$ of water, to the clear colorless solution saturated sodium bicarbonate was added until effervescence ceased $(\mathrm{pH} \sim 6)$. The clear colorless solution was heated to $70{ }^{\circ} \mathrm{C}$, and pyridazine $(0.207 \mathrm{~mL}, 2.87 \mathrm{mmol})$ was added dropwise, then the reaction was stirred at $70{ }^{\circ} \mathrm{C}$ for $2 \mathrm{~h}$. The reaction mixture was then cooled to room temperature, and neutralized with saturated sodium bicarbonate (until effervescence ceased), then a solution of 4-ethynylpyridine $\mathrm{HCl}(100 \mathrm{mg}, 0.716 \mu \mathrm{mol})$ in DCM (5 $\mathrm{mL}$ ) was added followed by $\mathrm{KOH}(40 \mathrm{mg}, 716 \mu \mathrm{mol})$. The reaction mixture was stirred at room temperature for $16 \mathrm{~h}$. After completion of reaction the reaction mixture was diluted with DCM, washed with water, brine and dried over sodium sulfate, filtered, and evaporated to get the crude product. Column purification was performed using EtOAc/hex $50-100 \%$ to yield the product as an off-white solid (16 mg, 11\%). ${ }^{1} \mathrm{H}$ NMR (500 MHz, chloroform- $d$ ) $\delta$ ppm 8.68 (dd, $J=$ 4.4, $2.0 \mathrm{~Hz}, 2 \mathrm{H}$ ), 8.39 (dd, $J=4.4,2.0 \mathrm{~Hz}, 1 \mathrm{H}), 8.35$ (s, $1 \mathrm{H}), 8.27$ (dd, $J=9.3,2.0 \mathrm{~Hz}, 1 \mathrm{H}), 7.50(\mathrm{dd}, J=4.4,2.0 \mathrm{~Hz}, 2 \mathrm{H}), 7.17$ (dd, $J$ $=9.3,4.4 \mathrm{~Hz}, 1 \mathrm{H}) . \mathrm{LC}-\mathrm{MS}(\mathrm{m} / z): 196.9[\mathrm{M}+\mathrm{H}]^{+}$.

3-((4-(Pyrazolo[1,5-b]pyridazin-3-yl)pyridin-2-yl)amino)benzonitrile (18d). In a vial $30(50 \mathrm{mg}, 217 \mu \mathrm{mol})$, cesium carbonate $(212 \mathrm{mg}, 650 \mu \mathrm{mol})$, palladium(II) acetate $(2.43 \mathrm{mg}, 11$ $\mu \mathrm{mol})$, Xantphos (12.5 mg, $22 \mu \mathrm{mol})$, and 3-aminobenzonitrile (25.6 $\mathrm{mg}, 217 \mu \mathrm{mol})$ were added followed by anhydrous dioxane $(1.5 \mathrm{~mL})$ and the vial was sealed. The reaction mixture was evacuated and backfilled with $\mathrm{N}_{2}$ three times. The reaction mixture was then subjected to microwave irradiation at $160{ }^{\circ} \mathrm{C}$ for $1 \mathrm{~h}$, then filtered through Celite and washed with EtOAc, and evaporated to dryness. Column purification was performed using $\mathrm{MeOH} / \mathrm{DCM} 2-10 \%$ followed by reverse phase column purification using ACN/water 5$95 \%$ with $0.1 \%$ formic acid, to afford the title compound as a yellow solid (6.6 mg, 10\%). ${ }^{1} \mathrm{H}$ NMR (500 MHz, chloroform- $d$ ) $\delta$ ppm 8.39 $(\mathrm{dd}, J=4.4,2.0 \mathrm{~Hz}, 1 \mathrm{H}), 8.30-8.36(\mathrm{~m}, 2 \mathrm{H}), 8.24(\mathrm{dd}, J=8.8,2.0$ $\mathrm{Hz}, 1 \mathrm{H}), 7.99-8.04(\mathrm{~s}, 1 \mathrm{H}), 7.64(\mathrm{~d}, J=7.8 \mathrm{~Hz}, 1 \mathrm{H}), 7.43$ (t, $J=$ $7.8 \mathrm{~Hz}, 1 \mathrm{H}), 7.31(\mathrm{~d}, J=7.8 \mathrm{~Hz}, 1 \mathrm{H}), 7.17(\mathrm{dd}, J=8.8,4.4 \mathrm{~Hz}, 1$ H), $7.07(\mathrm{~d}, J=5.4 \mathrm{~Hz}, 1 \mathrm{H}), 6.98(\mathrm{~s}, 1 \mathrm{H}), 6.84(\mathrm{br} \mathrm{s}, 1 \mathrm{H})$. LC-MS $(\mathrm{m} / z): 313.1[\mathrm{M}+\mathrm{H}]^{+}$.

3-((4-Methyl-6-(pyrazolo[1,5-b]pyridazin-3-yl)pyrimidin-2yl)amino)benzonitrile (19a). In a vial 26 (30 mg, $122 \mu \mathrm{mol})$ and 3aminobenzonitrile $(29 \mathrm{mg}, 244 \mu \mathrm{mol})$ were stirred in $n-\mathrm{BuOH}(1.5$ $\mathrm{mL}$ ) and subjected to microwave irradiation at $150{ }^{\circ} \mathrm{C}$ for $2 \mathrm{~h}$. Reaction was filtered and washed with diethyl ether, the precipitate was taken up in DCM and washed with a saturated sodium bicarbonate solution and brine, then dried over magnesium sulfate, filtered, and evaporated in vacuo, to yield the product as a white solid $(19.8 \mathrm{mg}, 50 \%) .{ }^{1} \mathrm{H}$ NMR (500 MHz, DMSO- $\left.d_{6}\right) \delta \mathrm{ppm} 9.89$ (s, 1 $\mathrm{H}), 9.05-9.11(\mathrm{~m}, 1 \mathrm{H}), 8.87(\mathrm{~s}, 1 \mathrm{H}), 8.61(\mathrm{dd}, J=4.4,2.0 \mathrm{~Hz}, 1$ $\mathrm{H}), 8.34-8.37(\mathrm{~m}, 1 \mathrm{H}), 7.97(\mathrm{~d}, J=7.8 \mathrm{~Hz}, 1 \mathrm{H}), 7.53(\mathrm{t}, J=7.8 \mathrm{~Hz}$, $1 \mathrm{H}), 7.45(\mathrm{dd}, J=9.3,4.4 \mathrm{~Hz}, 1 \mathrm{H}), 7.38-7.42(\mathrm{~m}, 2 \mathrm{H}), 2.43(\mathrm{~s}, 3$ H). LC-MS $(m / z): 328.2[\mathrm{M}+\mathrm{H}]^{+}$.

3-((5-Methyl-4-(pyrazolo[1,5-b]pyridazin-3-yl)pyrimidin-2yl)amino)benzonitrile (19b). In a vial $29(35 \mathrm{mg}, 140 \mu \mathrm{mol}), 3-$ aminobenzonitrile $(34 \mathrm{mg}, 430 \mu \mathrm{mol})$, cesium carbonate $(139 \mathrm{mg}$, $427 \mu \mathrm{mol})$, palladium(II) acetate $(1.6 \mathrm{mg}, 7.1 \mu \mathrm{mol})$, and Xantphos $(8.2 \mathrm{mg}, 14 \mu \mathrm{mol})$ were stirred in $1.5 \mathrm{~mL}$ of anhydrous dioxane. The reaction mixture was sealed and then evacuated and backfilled with $\mathrm{N}_{2}$ three times. The reaction mixture was then subjected to microwave irradiation at $130{ }^{\circ} \mathrm{C}$ for $1 \mathrm{~h}$. The reaction was filtered through Celite and washed with EtOAc, then evaporated to dryness. Column 
purification was performed using $\mathrm{MeOH} / \mathrm{DCM} 0-5 \%$, followed by another column purification using $\mathrm{MeOH} / \mathrm{DCM} 1-3 \%$ to afford the title compound as a white solid (7.4 mg, 16\%). ${ }^{1} \mathrm{H}$ NMR $(500 \mathrm{MHz}$, DMSO- $\left.d_{6}\right) \delta$ ppm $9.87(\mathrm{~s}, 1 \mathrm{H}), 9.11(\mathrm{dd}, J=9.3,2.0 \mathrm{~Hz}, 1 \mathrm{H}), 8.71$ $(\mathrm{s}, 1 \mathrm{H}), 8.66(\mathrm{dd}, J=4.4,2.0 \mathrm{~Hz}, 1 \mathrm{H}), 8.46-8.49(\mathrm{~m}, 1 \mathrm{H}), 8.36(\mathrm{t}$, $J=2.0 \mathrm{~Hz}, 1 \mathrm{H}), 7.93-7.98(\mathrm{~m}, 1 \mathrm{H}), 7.51(\mathrm{t}, J=7.8 \mathrm{~Hz}, 1 \mathrm{H}), 7.46$ (dd, $J=9.3,4.4 \mathrm{~Hz}, 1 \mathrm{H}), 7.36-7.40(\mathrm{~m}, 1 \mathrm{H}), 2.46(\mathrm{~s}, 3 \mathrm{H}) . \mathrm{LC}-$ MS $(m / z): 328.1[\mathrm{M}+\mathrm{H}]^{+}$.

3-((4-(Pyrazolo[1,5-b]pyridazin-3-yl)pyrimidin-2-yl)oxy)benzonitrile (20a). 3-Hydroxybenzonitrile $(8 \mathrm{mg}, 65 \mu \mathrm{mol})$ in anhydrous DMF was stirred with potassium carbonate $(13 \mathrm{mg}, 97$ $\mu \mathrm{mol}$ ) at room temperature under $\mathrm{N}_{2}$ for $30 \mathrm{~min}$, then $7 \mathrm{a}(15 \mathrm{mg}, 65$ $\mu \mathrm{mol}$ ) was added and the reaction mixture was stirred at $80^{\circ} \mathrm{C}$ for 16 h. After completion of reaction, the reaction mixture was dumped in water and extracted with EtOAc. Organic layer was then washed with water, brine and dried over sodium sulfate, decanted and concentrated to get the crude product which was purified by column chromatography using acetone/hex 20-50\% $15 \mathrm{CV}$ then 50-100\% $5 \mathrm{CV}$ to afford the title compound as a white solid $(11 \mathrm{mg}, 51 \%) .{ }^{1} \mathrm{H}$ NMR (500 MHz, chloroform- $d$ ) $\delta$ ppm $8.56(\mathrm{~d}, J=5.4 \mathrm{~Hz}, 1 \mathrm{H})$, $8.54(\mathrm{~s}, 1 \mathrm{H}), 8.39-8.45(\mathrm{~m}, 2 \mathrm{H}), 7.59-7.66(\mathrm{~m}, 3 \mathrm{H}), 7.53-7.57$ $(\mathrm{m}, 1 \mathrm{H}), 7.40(\mathrm{~d}, J=5.4 \mathrm{~Hz}, 1 \mathrm{H}), 7.11(\mathrm{dd}, J=8.8,4.4 \mathrm{~Hz}, 1 \mathrm{H})$. LC-MS $(m / z): 315.0[\mathrm{M}+\mathrm{H}]^{+}$.

3-(Methyl(4-(pyrazolo[1,5-b]pyridazin-3-yl)pyrimidin-2-yl)amino)benzonitrile (20b). In a vial $7 \mathrm{a}(100 \mathrm{mg}, 430 \mu \mathrm{mol})$, cesium carbonate (420 mg, $1.3 \mathrm{mmol})$, 3-(methylamino)benzonitrile (110 $\mathrm{mg}, 860 \mu \mathrm{mol})$, palladium(II) acetate $(4.8 \mathrm{mg}, 22 \mu \mathrm{mol})$, and Xantphos $(27 \mathrm{mg}, 43 \mu \mathrm{mol})$ were added in $5 \mathrm{~mL}$ of anhydrous dioxane. The reaction mixture was sealed then evacuated and backfilled with $\mathrm{N}_{2}$ three times. The reaction mixture was then subjected to microwave irradiation at $160{ }^{\circ} \mathrm{C}$ for $1 \mathrm{~h}$. The reaction was filtered through Celite and washed with EtOAc, then evaporated to dryness. Column purification was done using $\mathrm{MeOH} / \mathrm{DCM} 0-4 \%$, followed by isocratic column purification $80 \% \mathrm{EtOAc} /$ hexanes affording the title compound as an off-white solid $(18.8 \mathrm{mg}, 13 \%)$. ${ }^{1} \mathrm{H}$ NMR $\left(500 \mathrm{MHz}\right.$, DMSO- $\left.d_{6}\right) \delta \mathrm{ppm} 8.88(\mathrm{~s}, 1 \mathrm{H}), 8.58(\mathrm{dd}, J=$ 4.4, $2.0 \mathrm{~Hz}, 1 \mathrm{H}), 8.45(\mathrm{~d}, J=5.4 \mathrm{~Hz}, 1 \mathrm{H}), 8.38(\mathrm{dd}, J=9.3,2.0 \mathrm{~Hz}$, $1 \mathrm{H}), 8.00(\mathrm{~s}, 1 \mathrm{H}), 7.83(\mathrm{~d}, J=7.8 \mathrm{~Hz}, 1 \mathrm{H}), 7.75(\mathrm{~d}, J=7.8 \mathrm{~Hz}, 1$ $\mathrm{H}), 7.66(\mathrm{t}, J=7.8 \mathrm{~Hz}, 1 \mathrm{H}), 7.38(\mathrm{~d}, J=5.4 \mathrm{~Hz}, 1 \mathrm{H}), 7.30(\mathrm{dd}, J=$ 9.3, $4.4 \mathrm{~Hz}, 1 \mathrm{H}), 3.59(\mathrm{~s}, 3 \mathrm{H})$. LC-MS $(\mathrm{m} / z): 328.2[\mathrm{M}+\mathrm{H}]^{+}$.

4-(Pyrazolo[1,5-b]pyridazin-3-yl)-N-(3-(trifluoromethyl)phenyl)pyrimidin-2-amine (20c). In a vial $7 \mathrm{a}(50 \mathrm{mg}, 216 \mu \mathrm{mol})$, 3 -(trifluoromethyl)aniline $(67 \mu \mathrm{L}, 540 \mu \mathrm{mol})$ were stirred in $n$-BuOH $(1.5 \mathrm{~mL})$, and the reaction mixture was subjected to microwave irradiation at $150{ }^{\circ} \mathrm{C}$ for $2 \mathrm{~h}$. After completion the reaction was evaporated to dryness and column purification was performed using EtOAc/hex, 33-66\% to afford the title compound as a white solid (52 mg, 68\%). ${ }^{1} \mathrm{H}$ NMR (500 MHz, DMSO-d $\left.{ }_{6}\right) \delta$ ppm 9.95 (s, $1 \mathrm{H}$ ), 9.10-9.18 (m, $1 \mathrm{H}), 8.93(\mathrm{~s}, 1 \mathrm{H}), 8.64(\mathrm{dd}, J=4.4,2.0 \mathrm{~Hz}, 1 \mathrm{H})$, $8.55(\mathrm{~d}, J=5.4 \mathrm{~Hz}, 1 \mathrm{H}), 8.30(\mathrm{~s}, 1 \mathrm{H}), 7.97(\mathrm{~d}, J=8.3 \mathrm{~Hz}, 1 \mathrm{H}), 7.57$ $(\mathrm{t}, J=8.3 \mathrm{~Hz}, 1 \mathrm{H}), 7.43-7.50(\mathrm{~m}, 2 \mathrm{H}), 7.33(\mathrm{~d}, J=8.3 \mathrm{~Hz}, 1 \mathrm{H})$. LC-MS $(\mathrm{m} / z): 357.0[\mathrm{M}+\mathrm{H}]^{+}$.

2-Fluoro-3-((4-(pyrazolo[1,5-b]pyridazin-3-yl)pyrimidin-2yl)amino)benzonitrile (20d). In a vial 3-(2-chloropyrimidin-4yl)pyrazolo[1,5-b]pyridazine $7 \mathrm{a}(40 \mathrm{mg}, 173 \mu \mathrm{mol})$, cesium carbonate (169 mg, $518 \mu \mathrm{mol}$ ), 3-amino-2-fluorobenzonitrile $(47 \mathrm{mg}, 345$ $\mu \mathrm{mol})$, palladium(II) acetate $(2 \mathrm{mg}, 8.6 \mu \mathrm{mol})$, and Xantphos $(10 \mathrm{mg}$, $17 \mu \mathrm{mol})$ were added in anhydrous dioxane $(1.5 \mathrm{~mL})$, the reaction mixture was sealed then evacuated and backfilled with $\mathrm{N}_{2}$ three times. The reaction mixture was then subjected to microwave irradiation at $160{ }^{\circ} \mathrm{C}$ for $1 \mathrm{~h}$. The reaction was filtered through Celite and washed with EtOAc, then evaporated to dryness. The reaction mixture was taken up in DCM and water, and extracted $2 \mathrm{X}$ into DCM, then washed with brine, dried with $\mathrm{Na}_{2} \mathrm{SO}_{4}$, filtered, and evaporated in vacuo. Column purification was performed using EtOAc/hex 25$100 \%$ followed by reverse phase column purification using ACN/ water $5-95 \%$ with $0.1 \%$ ammonium hydroxide, to afford the title compound as a white solid $(5.0 \mathrm{mg}, 9 \%) .{ }^{1} \mathrm{H}$ NMR $(400 \mathrm{MHz}$, DMSO- $\left.d_{6}\right) \delta$ ppm $9.62(\mathrm{~s}, 1 \mathrm{H}), 8.94-9.01(\mathrm{~m}, 1 \mathrm{H}), 8.90(\mathrm{~s}, 1 \mathrm{H})$, $8.56-8.63(\mathrm{~m}, 1 \mathrm{H}), 8.45(\mathrm{~d}, J=5.1 \mathrm{~Hz}, 1 \mathrm{H}), 8.19(\mathrm{t}, J=7.3 \mathrm{~Hz}, 1$
$\mathrm{H}), 7.65(\mathrm{t}, J=7.3 \mathrm{~Hz}, 1 \mathrm{H}), 7.43(\mathrm{~s}, 3 \mathrm{H}) . \mathrm{LC}-\mathrm{MS} 332.0(\mathrm{~m} / z)$ : [M $+\mathrm{H}]^{+}$.

4-Fluoro-3-((4-(pyrazolo[1,5-b]pyridazin-3-yl)pyrimidin-2yl)amino)benzonitrile (20e). In a vial $7 \mathrm{a}(40 \mathrm{mg}, 173 \mu \mathrm{mol})$, cesium carbonate ( $169 \mathrm{mg}, 518 \mu \mathrm{mol}$ ), 3-amino-4-fluorobenzonitrile (47 mg, $345 \mu \mathrm{mol}$ ), palladium(II) acetate $(2 \mathrm{mg}, 8.6 \mu \mathrm{mol}$ ), and Xantphos $(10 \mathrm{mg}, 17 \mu \mathrm{mol})$ were added with anhydrous dioxane (1.5 $\mathrm{mL}$ ), the reaction mixture was sealed, then evacuated and backfilled with $\mathrm{N}_{2}$ three times. The reaction mixture was then subjected to microwave irradiation at $160{ }^{\circ} \mathrm{C}$ for $1 \mathrm{~h}$. The reaction was filtered through Celite and washed with EtOAc, then evaporated to dryness. Column purification was done using EtOAc/hex 25-100\%, followed by $\mathrm{MeOH} / \mathrm{DCM} 4 \%$ with $5 \%$ ammonium hydroxide, followed by reverse phase column purification using $\mathrm{ACN} /$ water 5-95\% with $0.1 \%$ ammonium hydroxide, to afford the title compound as a white solid (5.0 mg, 8.7\%). ${ }^{1} \mathrm{H}$ NMR (400 MHz, DMSO- $\left.d_{6}\right) \delta \mathrm{ppm} 9.60(\mathrm{~s}$, $1 \mathrm{H}), 9.11(\mathrm{~d}, J=8.8 \mathrm{~Hz}, 1 \mathrm{H}), 8.93(\mathrm{~s}, 1 \mathrm{H}), 8.63(\mathrm{dd}, J=4.4,2.2$ $\mathrm{Hz}, 1 \mathrm{H}), 8.49-8.58(\mathrm{~m}, 2 \mathrm{H}), 7.62-7.67(\mathrm{~m}, 1 \mathrm{H}), 7.49-7.59(\mathrm{~m}, 2$ $\mathrm{H}), 7.43(\mathrm{dd}, J=8.8,4.4 \mathrm{~Hz}, 1 \mathrm{H})$. LC-MS $(\mathrm{m} / z): 332.0[\mathrm{M}+\mathrm{H}]^{+}$.

4-(Pyrazolo[1,5-b]pyridazin-3-yl)- $\mathrm{N}$-(pyridin-2-yl)pyrimidin2-amine (20f). In a vial $7 \mathrm{a}(40 \mathrm{mg}, 173 \mu \mathrm{mol})$, cesium carbonate (169 mg, $518 \mu \mathrm{mol}$ ), 2-aminopyridine $(33 \mathrm{mg}, 350 \mu \mathrm{mol}$ ), palladium(II) acetate $(2 \mathrm{mg}, 8.6 \mu \mathrm{mol})$, and Xantphos $(10 \mathrm{mg}, 17$ $\mu \mathrm{mol})$ were added to anhydrous dioxane $(1.5 \mathrm{~mL})$, the reaction mixture was sealed then evacuated and backfilled with $\mathrm{N}_{2}$ three times. The reaction mixture was then subjected to microwave irradiation at $160{ }^{\circ} \mathrm{C}$ for $1 \mathrm{~h}$. The reaction was filtered through Celite and washed with EtOAc, then evaporated to dryness. Column purification was performed using EtOAc/hex 50-100\%, to afford the title compound as a pale-yellow solid $(20.2 \mathrm{mg}, 41 \%){ }^{1} \mathrm{H}$ NMR $(400 \mathrm{MHz}$, chloroform- $d$ ) $\delta$ ppm $9.00(\mathrm{dd}, J=8.8,2.2 \mathrm{~Hz}, 1 \mathrm{H}), 8.54(\mathrm{~s}, 1$ $\mathrm{H}), 8.51(\mathrm{~d}, J=5.1 \mathrm{~Hz}, 1 \mathrm{H}), 8.43(\mathrm{dd}, J=4.4,2.2 \mathrm{~Hz}, 1 \mathrm{H}), 8.40(\mathrm{~d}$, $J=8.1 \mathrm{~Hz}, 1 \mathrm{H}), 8.34(\mathrm{~d}, J=5.1 \mathrm{~Hz}, 1 \mathrm{H}), 7.96(\mathrm{br} \mathrm{s}, 1 \mathrm{H}), 7.69-$ $7.76(\mathrm{~m}, 1 \mathrm{H}), 7.22(\mathrm{dd}, J=8.8,4.4 \mathrm{~Hz}, 1 \mathrm{H}), 7.16(\mathrm{~d}, J=5.1 \mathrm{~Hz}, 1$ $\mathrm{H}), 6.98(\mathrm{dd}, J=8.1,5.1 \mathrm{~Hz}, 1 \mathrm{H})$. LC-MS $(\mathrm{m} / z): 290.1[\mathrm{M}+\mathrm{H}]^{+}$.

4-(Pyrazolo[1,5-b]pyridazin-3-yl)- $N$-(pyridin-3-yl)pyrimidin2-amine $(20 \mathrm{~g})$. In a vial $7 \mathrm{a}(50 \mathrm{mg}, 216 \mu \mathrm{mol})$, cesium carbonate (140 mg, $431 \mu \mathrm{mol})$, palladium(II) acetate $(0.9 \mathrm{mg}, 4 \mu \mathrm{mol})$, and Xantphos $(4 \mathrm{mg}, 7 \mu \mathrm{mol}$ ) were dissolved in $2 \mathrm{~mL}$ of anhydrous dioxane, the reaction mixture was sealed then evacuated and backfilled with $\mathrm{N}_{2}$ three times. The reaction mixture was then subjected to microwave irradiation at $160{ }^{\circ} \mathrm{C}$ for $1 \mathrm{~h}$. The reaction was filtered through Celite and washed with EtOAc, then concentrated in vacuo. Reverse phase preparative HPLC purification was performed using $\mathrm{ACN} /$ water $5-95 \%$ with $0.1 \%$ formic acid, to afford the title compound as a white solid $(9.1 \mathrm{mg}, 15 \%)$, isolated as a $0.5 \mathrm{eq}$ formic acid solvate. ${ }^{1} \mathrm{H}$ NMR (500 MHz, DMSO- $\left.d_{6}\right) \delta$ ppm $9.79(\mathrm{~s}, 1 \mathrm{H})$, 9.12-9.18 (m, $1 \mathrm{H}), 8.92(\mathrm{~s}, 1 \mathrm{H}), 8.89(\mathrm{~d}, J=2.0 \mathrm{~Hz}, 1 \mathrm{H}), 8.63$ $(\mathrm{dd}, J=4.4,2.0 \mathrm{~Hz}, 1 \mathrm{H}), 8.51(\mathrm{~d}, J=5.4 \mathrm{~Hz}, 1 \mathrm{H}), 8.41(\mathrm{br} \mathrm{s}, 1 \mathrm{H})$, $8.24(\mathrm{~d}, J=8.3 \mathrm{~Hz}, 1 \mathrm{H}), 8.20(\mathrm{~d}, J=4.9 \mathrm{~Hz}, 1 \mathrm{H}), 7.48$ (dd, $J=8.8$, $4.4 \mathrm{~Hz}, 1 \mathrm{H}), 7.44(\mathrm{~d}, J=5.4 \mathrm{~Hz}, 1 \mathrm{H}), 7.37(\mathrm{dd}, J=8.3,4.9 \mathrm{~Hz}, 1$ H). LC-MS $(m / z): 290.2[\mathrm{M}+\mathrm{H}]^{+}$.

4-(Pyrazolo[1,5-b]pyridazin-3-yl)-N-(pyridin-4-yl)pyrimidin2-amine (20h). In a vial $7 \mathrm{a}(30 \mathrm{mg}, 130 \mu \mathrm{mol})$ and 4-aminopyridine $(18 \mathrm{mg}, 190 \mu \mathrm{mol})$ were stirred in $n-\mathrm{BuOH}(1.5 \mathrm{~mL})$ and heated to $150{ }^{\circ} \mathrm{C}$ for $2 \mathrm{~h}$. The reaction was concentrated in vacuo. Column purification was performed using EtOAc/hexanes $50-75 \%$ then changed to $\mathrm{MeOH} / \mathrm{DCM} 0-20 \%$, a second column was run using an isocratic method $\mathrm{MeOH} / \mathrm{DCM} 30 \%$, to afford the title compound as a yellow solid (5.2 mg, 14\%). ${ }^{1} \mathrm{H}$ NMR (400 MHz, methanol- $\left.d_{4}\right) \delta$ ppm 9.39 (d, $J=7.3 \mathrm{~Hz}, 2 \mathrm{H}), 9.05(\mathrm{~d}, J=9.5 \mathrm{~Hz}, 1 \mathrm{H}), 8.93(\mathrm{~s}, 1$ $\mathrm{H}), 8.85(\mathrm{~d}, J=5.1 \mathrm{~Hz}, 1 \mathrm{H}), 8.61(\mathrm{~d}, J=4.4 \mathrm{~Hz}, 1 \mathrm{H}), 8.03(\mathrm{~d}, J=$ $5.1 \mathrm{~Hz}, 1 \mathrm{H}), 7.55(\mathrm{dd}, J=9.5,4.4 \mathrm{~Hz}, 1 \mathrm{H}), 7.09(\mathrm{~d}, J=7.3 \mathrm{~Hz}, 2$ H). LC-MS $(m / z): 290.1[\mathrm{M}+\mathrm{H}]^{+}$.

4-(Pyrazolo[1,5-b]pyridazin-3-yl)-N-(pyrimidin-5-yl)pyrimidin-2-amine (20i). In a vial $7 \mathrm{a}(50 \mathrm{mg}, 220 \mu \mathrm{mol}), 5$ aminopyrimidine (205 mg, $2.2 \mathrm{mmol}$ ), palladium(II) acetate $(2.4 \mathrm{mg}$, $11 \mu \mathrm{mol})$, Xantphos $(12.5 \mathrm{mg}, 21.6 \mu \mathrm{mol})$, and cesium carbonate $(211 \mathrm{mg}, 648 \mu \mathrm{mol})$ were stirred in anhydrous dioxane $(5 \mathrm{~mL})$. The reaction mixture was sealed then evacuated and backfilled with $\mathrm{N}_{2}$ 
three times. The reaction was then subjected to microwave irradiation at $160{ }^{\circ} \mathrm{C}$ for $1.5 \mathrm{~h}$. The reaction was filtered through Celite and washed with EtOAc, then evaporated to dryness. Column purification was performed using $\mathrm{MeOH} / \mathrm{DCM} 0-5 \%$, followed by reverse phase preparative HPLC column purification using ACN/water 5-70\% with $0.1 \%$ formic acid, to afford the title compound as a white solid (3.6 $\mathrm{mg}, 6 \%) .{ }^{1} \mathrm{H}$ NMR (500 MHz, chloroform- $d$ ) $\delta$ ppm 9.14 (s, $2 \mathrm{H}$ ), $8.97(\mathrm{~s}, 1 \mathrm{H}), 8.85(\mathrm{dd}, J=8.8,2.0 \mathrm{~Hz}, 1 \mathrm{H}), 8.56(\mathrm{~s}, 1 \mathrm{H}), 8.50(\mathrm{~d}, J$ $=5.4 \mathrm{~Hz}, 1 \mathrm{H}), 8.44(\mathrm{dd}, J=4.9,2.0 \mathrm{~Hz}, 1 \mathrm{H}), 7.25(\mathrm{dd}, J=8.8,4.4$ $\mathrm{Hz}, 1 \mathrm{H}), 7.20(\mathrm{~d}, J=5.4 \mathrm{~Hz}, 1 \mathrm{H}), 7.05(\mathrm{br} \mathrm{s}, 1 \mathrm{H})$. LC-MS $(\mathrm{m} / z)$ : $291.2[\mathrm{M}+\mathrm{H}]^{+}$.

N-(4-(Pyrazolo[1,5-b]pyridazin-3-yl)pyrimidin-2-yl)pyridazin-4-amine (20j). In a vial $7 \mathrm{a}(50 \mathrm{mg}, 216 \mu \mathrm{mol})$ and 4 aminopyridazine $(41 \mathrm{mg}, 432 \mu \mathrm{mol})$ were stirred in $n-\mathrm{BuOH}(1.5$ $\mathrm{mL}$ ) and subject to microwave irradiation to $120^{\circ} \mathrm{C}$ for $30 \mathrm{~min}$. The reaction was concentrated in vacuo and column purification was performed $\mathrm{MeOH} / \mathrm{DCM} 2-20 \%$ followed by reverse phase preparative HPLC purification using ACN/water $5-50 \%$ with $0.1 \%$ formic acid, to afford the title compound as a yellow solid $(5.5 \mathrm{mg}$, $11 \%) .{ }^{1} \mathrm{H}$ NMR (500 MHz, DMSO- $\left.d_{6}\right) \delta \mathrm{ppm} 9.21-9.26(\mathrm{~m}, 1 \mathrm{H})$, $9.13(\mathrm{dd}, J=8.78,2.0 \mathrm{~Hz}, 1 \mathrm{H}), 9.10(\mathrm{~s}, 1 \mathrm{H}), 8.87(\mathrm{~d}, J=5.4 \mathrm{~Hz}, 1$ $\mathrm{H}), 8.69(\mathrm{dd}, J=4.4,2.0 \mathrm{~Hz}, 1 \mathrm{H}), 8.35-8.41(\mathrm{~m}, 2 \mathrm{H}), 8.05(\mathrm{~d}, J=$ $5.4 \mathrm{~Hz}, 1 \mathrm{H}), 7.58(\mathrm{dd}, J=8.8,4.4 \mathrm{~Hz}, 1 \mathrm{H}), 6.84-6.89(\mathrm{~m}, 1 \mathrm{H})$. LC-MS $(m / z): 291.1[\mathrm{M}+\mathrm{H}]^{+}$.

$N$-(6-Methylpyridin-3-yl)-4-(pyrazolo[1,5-b]pyridazin-3-yl)pyrimidin-2-amine (20k). In a vial $7 \mathrm{a}(50 \mathrm{mg}, 220 \mu \mathrm{mol}), 3$-amino6-methylpyridine $(47 \mathrm{mg}, 430 \mu \mathrm{mol})$, cesium carbonate $(211 \mathrm{mg}, 648$ $\mu \mathrm{mol})$, palladium(II) acetate $(2.4 \mathrm{mg}, 11 \mu \mathrm{mol})$, and Xantphos (12.5 $\mathrm{mg}, 21.6 \mu \mathrm{mol})$ were stirred in anhydrous dioxane $(1.5 \mathrm{~mL})$. The reaction mixture was sealed then evacuated and backfilled with $\mathrm{N}_{2}$ three times. The reaction mixture was then subjected to microwave irradiation at $160{ }^{\circ} \mathrm{C}$ for $1 \mathrm{~h}$. The reaction was filtered through Celite and washed with EtOAc, then evaporated to dryness. Reverse phase preparative HPLC column purification was performed using ACN/ water $5-70 \%$ with $0.1 \%$ formic acid. The compound was then taken up in DCM and stirred with resin-bound silicon carbonate for $12 \mathrm{~h}$ then filtered and evaporated in vacuo, to afford the title compound as an off-white solid $(25.9 \mathrm{mg}, 40 \%) .{ }^{1} \mathrm{H}$ NMR $\left(500 \mathrm{MHz}, \mathrm{DMSO}-d_{6}\right) \delta$ ppm $9.64(\mathrm{~s}, 1 \mathrm{H}), 9.09-9.16(\mathrm{~m}, 1 \mathrm{H}), 8.90(\mathrm{~s}, 1 \mathrm{H}), 8.73(\mathrm{~d}, J=2.4$ $\mathrm{Hz}, 1 \mathrm{H}), 8.62(\mathrm{dd}, J=4.4,2.0 \mathrm{~Hz}, 1 \mathrm{H}), 8.48(\mathrm{~d}, J=5.4 \mathrm{~Hz}, 1 \mathrm{H})$, $8.11(\mathrm{dd}, J=8.8,2.4 \mathrm{~Hz}, 1 \mathrm{H}), 7.47(\mathrm{dd}, J=8.8,4.4 \mathrm{~Hz}, 1 \mathrm{H}), 7.40$ (d, $J=5.4 \mathrm{~Hz}, 1 \mathrm{H}), 7.22(\mathrm{~d}, J=8.8 \mathrm{~Hz}, 1 \mathrm{H}), 2.44(\mathrm{~s}, 3 \mathrm{H})$. LC-MS $(\mathrm{m} / z): 304.2[\mathrm{M}+\mathrm{H}]^{+}$.

3-((4-(Pyrazolo[1,5-b]pyridazin-3-yl)pyrimidin-2-yl)amino)propan-1-ol (20l). To an oven-dried flask 3-aminopropan-1-ol (7 $\mathrm{mg}, 90 \mu \mathrm{mol})$ and $7 \mathrm{a}(10 \mathrm{mg}, 43 \mu \mathrm{mol})$ were added in $n-\mathrm{BuOH}$. The reaction mixture was stirred at $110{ }^{\circ} \mathrm{C}$ for $16 \mathrm{~h}$. After completion of reaction mixture was evaporated to dryness and the solid obtained was titrated with cold methanol, filtered and dried under high vacuum affording the title compound as a solid $(6 \mathrm{mg}, 68 \%) .{ }^{1} \mathrm{H}$ NMR (400 MHz, DMSO- $\left.d_{6}\right) \delta$ ppm 9.01-9.25 (m, $\left.1 \mathrm{H}\right), 8.82(\mathrm{~s}, 1 \mathrm{H}), 8.58(\mathrm{~d}, J$ $=5.1 \mathrm{~Hz}, 1 \mathrm{H}), 8.27(\mathrm{~d}, J=4.4 \mathrm{~Hz}, 1 \mathrm{H}), 7.41(\mathrm{dd}, J=8.8,4.4 \mathrm{~Hz}, 1$ H), 7.19 (br s, $1 \mathrm{H}), 7.10(\mathrm{~d}, J=5.1 \mathrm{~Hz}, 1 \mathrm{H}), 4.53$ (br s, $1 \mathrm{H}), 3.37-$ $3.60(\mathrm{~m}, 4 \mathrm{H}), 1.64-1.82(\mathrm{~m}, 2 \mathrm{H})$. LC-MS $(\mathrm{m} / \mathrm{z}): 271.1[\mathrm{M}+\mathrm{H}]^{+}$.

N-(4-(Pyrazolo[1,5-b]pyridazin-3-yl)pyrimidin-2-yl)acrylamide $(20 \mathrm{~m})$. To the solution of $(10 \mathrm{mg}, 47 \mu \mathrm{mol}$, prepared by refluxing 3-(2-chloropyrimidin-4-yl)pyrazolo[1,5-b]pyridazine in liq $\mathrm{NH}_{3}$, added triethylamine $(10 \mu \mathrm{L}, 71 \mu \mathrm{mol})$ in $1 \mathrm{~mL}$ THF followed by acryloyl chloride $(6 \mu \mathrm{L}, 71 \mu \mathrm{mol})$, and reaction mixture was stirred at $50{ }^{\circ} \mathrm{C}$ overnight. The reaction mixture then evaporated to dryness and taken up in DCM, washed with water and brine then dried over sodium sulfate, decanted, and concentrated to get the crude product which was purified by column chromatography using EtOAc/hex 30$100 \% 12 \mathrm{CV}$ to afford the title compound as a solid $(6 \mathrm{mg}, 48 \%) .{ }^{1} \mathrm{H}$ NMR (400 MHz, DMSO- $\left.d_{6}\right) \delta$ ppm $10.93(\mathrm{~s}, 1 \mathrm{H}), 9.71(\mathrm{~d}, J=8.8$ $\mathrm{Hz}, 1 \mathrm{H}), 8.97(\mathrm{~s}, 1 \mathrm{H}), 8.57-8.70(\mathrm{~m}, 2 \mathrm{H}), 7.71(\mathrm{~d}, J=5.1 \mathrm{~Hz}, 1$ $\mathrm{H}), 7.53(\mathrm{dd}, J=8.8,4.4 \mathrm{~Hz}, 1 \mathrm{H}), 6.71(\mathrm{dd}, J=16.9,10.3 \mathrm{~Hz}, 1 \mathrm{H})$, $6.40(\mathrm{~d}, J=16.9 \mathrm{~Hz}, 1 \mathrm{H}), 5.85(\mathrm{~d}, J=10.3 \mathrm{~Hz}, 1 \mathrm{H})$. LC-MS $(\mathrm{m} /$ $z): 267.1[\mathrm{M}+\mathrm{H}]^{+}$.
4-(Pyrazolo[1,5-b]pyridazin-3-yl)pyrimidin-2-amine (20n). In a vial 10a $(34.3 \mathrm{mg}, 103 \mu \mathrm{mol})$ was dissolved in TFA $(2 \mathrm{~mL})$ and stirred at $80{ }^{\circ} \mathrm{C}$ for $20 \mathrm{~min}$. The reaction was quenched with saturated sodium bicarbonate and filtered. The precipitate was purified using column purification using $\mathrm{MeOH} / \mathrm{DCM} 5 \%$ to afford the title compound as a white solid $(8.1 \mathrm{mg}, 37 \%) .{ }^{1} \mathrm{H}$ NMR (400 $\mathrm{MHz}$, chloroform- $d$ ) $\delta$ ppm $8.99(\mathrm{~d}, J=8.8 \mathrm{~Hz}, 1 \mathrm{H}), 8.49(\mathrm{~s}, 1 \mathrm{H})$, $8.41(\mathrm{~d}, J=4.4 \mathrm{~Hz}, 1 \mathrm{H}), 8.32(\mathrm{~d}, J=5.1 \mathrm{~Hz}, 1 \mathrm{H}), 7.20(\mathrm{dd}, J=8.8$, $4.4 \mathrm{~Hz}, 1 \mathrm{H}), 6.99(\mathrm{~d}, J=5.1 \mathrm{~Hz}, 1 \mathrm{H}), 5.02(\mathrm{br} \mathrm{s}, 2 \mathrm{H})$. LC-MS $(\mathrm{m} /$ $z): 213.0[\mathrm{M}+\mathrm{H}]^{+}$.

N-Methyl-4-(pyrazolo[1,5-b]pyridazin-3-yl)pyrimidin-2amine (20o). In a vial $7 \mathrm{a}(30 \mathrm{mg}, 130 \mu \mathrm{mol})$ and methylamine $(2.0$ M solution in THF) $(129.5 \mu \mathrm{L}, 259 \mu \mathrm{mol})$ were stirred in $n-\mathrm{BuOH}$ and subjected to microwave irradiation at $150{ }^{\circ} \mathrm{C}$ for $2 \mathrm{~h}$. The reaction was concentrated in vacuo, then subjected to column purification using EtOAc/hexanes $50-100 \%$ to afford the title compound as an off-white solid (22.8 mg, 78\%). ${ }^{1} \mathrm{H}$ NMR (400 $\mathrm{MHz}$, methanol- $\left.d_{4}\right) \delta \mathrm{ppm} 9.12(\mathrm{dd}, J=8.8,2.2 \mathrm{~Hz}, 1 \mathrm{H}), 8.65$ (s, 1 $\mathrm{H}), 8.49(\mathrm{dd}, J=4.4,2.2 \mathrm{~Hz}, 1 \mathrm{H}), 8.22(\mathrm{~d}, J=5.1 \mathrm{~Hz}, 1 \mathrm{H}), 7.36$ $(\mathrm{dd}, J=8.8,4.4 \mathrm{~Hz}, 1 \mathrm{H}), 7.07(\mathrm{~d}, J=5.1 \mathrm{~Hz}, 1 \mathrm{H}), 3.02(\mathrm{~s}, 3 \mathrm{H})$. LC-MS $(m / z): 227.0[\mathrm{M}+\mathrm{H}]^{+}$.

$\mathrm{N}$-Isopropyl-4-(pyrazolo[1,5-b]pyridazin-3-yl)pyrimidin-2amine (20p). In a vial $7 \mathrm{a}(50 \mathrm{mg}, 220 \mu \mathrm{mol})$ and isopropylamine (35 $\mu \mathrm{L}, 430 \mu \mathrm{mol})$ were stirred in $n-\mathrm{BuOH}(1.5 \mathrm{~mL})$, and the reaction mixture was subjected to microwave irradiation at $150{ }^{\circ} \mathrm{C}$ for $2 \mathrm{~h}$. After completion of reaction mixture was evaporated to dryness. Column purification performed using reverse phase preparative HPLC using 5-35\% ACN/water system, affording the title compound as a yellow solid $(7.0 \mathrm{mg}, 15 \%) .{ }^{1} \mathrm{H}$ NMR $(500 \mathrm{MHz}$, methanol- $\left.d_{4}\right) \delta$ ppm 9.00-9.13 $(\mathrm{m}, 1 \mathrm{H}), 8.88(\mathrm{~s}, 1 \mathrm{H}), 8.64(\mathrm{dd}, J=$ 4.4, $2.0 \mathrm{~Hz}, 1 \mathrm{H}), 8.16(\mathrm{~d}, J=6.4 \mathrm{~Hz}, 1 \mathrm{H}), 7.57(\mathrm{dd}, J=8.8,4.4 \mathrm{~Hz}$, $1 \mathrm{H}), 7.38(\mathrm{~d}, J=6.4 \mathrm{~Hz}, 1 \mathrm{H}), 4.89-4.90(\mathrm{~m}, 1 \mathrm{H}), 1.40(\mathrm{~d}, J=6.35$ $\mathrm{Hz}, 6 \mathrm{H}) . \mathrm{LC}-\mathrm{MS}(\mathrm{m} / \mathrm{z}): 255.1[\mathrm{M}+\mathrm{H}]^{+}$.

$\mathrm{N}$-Cyclohexyl-4-(pyrazolo[1,5-b]pyridazin-3-yl)pyrimidin-2amine (20q). In a vial $7 \mathrm{a}(50 \mathrm{mg}, 216 \mu \mathrm{mol})$ and cyclohexylamine $(49 \mu \mathrm{L}, 432 \mu \mathrm{mol})$ were stirred in $1.5 \mathrm{~mL}$ of $n-\mathrm{BuOH}$, and the reaction was subjected to microwave irradiation at $150{ }^{\circ} \mathrm{C}$ for $2 \mathrm{~h}$, the reaction was then conventionally heated to $50{ }^{\circ} \mathrm{C}$ for $12 \mathrm{~h}$, and then subjected to microwave irradiation at $150{ }^{\circ} \mathrm{C}$ for $30 \mathrm{~min}$. The reaction was filtered and washed with diethyl ether to give the crude product in the precipitate. Reverse phase preparative HPLC purification was performed using ACN/water 5-95\% with $0.1 \%$ formic acid to afford the title compound as a white solid $(26.2 \mathrm{mg}, 41 \%) .{ }^{1} \mathrm{H}$ NMR (500 $\mathrm{MHz}$, chloroform- $d$ ) $\delta$ ppm $8.96(\mathrm{dd}, J=8.8,2.0 \mathrm{~Hz}, 1 \mathrm{H}), 8.46(\mathrm{~s}, 1$ $\mathrm{H}), 8.38(\mathrm{dd}, J=4.4,2.0 \mathrm{~Hz}, 1 \mathrm{H}), 8.23-8.32(\mathrm{~m}, 1 \mathrm{H}), 7.16(\mathrm{dd}, J=$ $8.8,4.5 \mathrm{~Hz}, 1 \mathrm{H}), 6.86(\mathrm{~d}, J=5.4 \mathrm{~Hz}, 1 \mathrm{H}), 5.12($ br s, $1 \mathrm{H}), 3.84-$ $3.95(\mathrm{~m}, 1 \mathrm{H}), 2.09-2.19(\mathrm{~m}, 2 \mathrm{H}), 1.76-1.87(\mathrm{~m}, 2 \mathrm{H}), 1.64-1.73$ $(\mathrm{m}, 1 \mathrm{H}), 1.41-1.53(\mathrm{~m}, 2 \mathrm{H}), 1.22-1.38(\mathrm{~m}, 3 \mathrm{H})$. LC-MS $(\mathrm{m} / \mathrm{z})$ : $295.1[\mathrm{M}+\mathrm{H}]^{+}$.

4-((4-(Pyrazolo[1,5-b]pyridazin-3-yl)pyrimidin-2-yl)amino)cyclohexan-1-ol (20r). In a vial 7a (0.040 g, $173 \mu \mathrm{mol})$, 4aminocyclohexanol $(0.040 \mathrm{~g}, 347 \mu \mathrm{mol})$ were stirred in $n-\mathrm{BuOH}(1.5$ $\mathrm{mL}$ ), and the reaction mixture was subjected to microwave irradiation at $150{ }^{\circ} \mathrm{C}$ for $2 \mathrm{~h}$. After completion of reaction mixture was filtered and washed with diethyl ether, the filtrate was evaporated to dryness and column purification was performed using $\mathrm{MeOH} / \mathrm{DCM} 2-4 \%$ to yield the title compound as a white solid $(6.0 \mathrm{mg}, 11 \%) .{ }^{1} \mathrm{H}$ NMR (500 MHz, methanol- $\left.d_{4}\right) \delta$ ppm 9.04-9.13 (m, $\left.1 \mathrm{H}\right), 8.64(\mathrm{~s}, 1 \mathrm{H})$, $8.49(\mathrm{dd}, J=4.4,2.0 \mathrm{~Hz}, 1 \mathrm{H}), 8.21(\mathrm{~d}, J=5.4 \mathrm{~Hz}, 1 \mathrm{H}), 7.36(\mathrm{dd}, J=$ 8.8, $4.4 \mathrm{~Hz}, 1 \mathrm{H}), 7.04(\mathrm{~d}, J=5.4 \mathrm{~Hz}, 1 \mathrm{H}), 3.76-3.87(\mathrm{~m}, 1 \mathrm{H})$, $3.58-3.67(\mathrm{~m}, 1 \mathrm{H}), 2.09-2.20(\mathrm{~m}, 2 \mathrm{H}), 1.98-2.08(\mathrm{~m}, 2 \mathrm{H}), 1.35-$ $1.53(\mathrm{~m}, 4 \mathrm{H})$. LC-MS $(\mathrm{m} / z): 311.1[\mathrm{M}+\mathrm{H}]^{+}$.

3-((4-(2-(4-Methoxyphenyl)pyrazolo[1,5-b]pyridazin-3-yl)pyrimidin-2-yl)amino)benzonitrile (21a). In a vial were added $7 \mathrm{f}$ $(20 \mathrm{mg}, 59 \mu \mathrm{mol})$, anhydrous $\mathrm{K}_{3} \mathrm{PO}_{4}(25 \mathrm{mg}, 118 \mu \mathrm{mol})$, XPhos $(4$ $\mathrm{mg}, 9 \mu \mathrm{mol})$, tris(dibenzylideneacetone)palladium(0) (3 mg, 3.0 $\mu \mathrm{mol})$, and 3 -aminobenzonitrile $(14 \mathrm{mg}, 118 \mu \mathrm{mol})$. The vial was sealed with a stir bar and evacuated and backfilled with $\mathrm{N}_{2}$ three times. Degassed anhydrous toluene $(1 \mathrm{~mL}$, dried over molecular sieves and stored under N2) was added to a sealed vial and the 
reaction mixture was degassed with nitrogen for an additional $5 \mathrm{~min}$. The reaction was stirred at $101{ }^{\circ} \mathrm{C}$ for $16 \mathrm{~h}$. The reaction mixture was evaporated to dryness and then extracted with DCM and washed with water, and brine then dried over sodium sulfate, decanted and concentrated to get the crude product. Purification was done by column chromatography using EtOAc/hex $40-100 \% 12 \mathrm{CV}$ to yield the title compound as a yellow solid ( $3 \mathrm{mg}, 12 \%) .{ }^{1} \mathrm{H}$ NMR (500 $\mathrm{MHz}$, chloroform- $d$ ) $\delta \mathrm{ppm} 8.71(\mathrm{dd}, J=9.0,1.5 \mathrm{~Hz}, 1 \mathrm{H}), 8.40(\mathrm{dd}, J$ $=4.5,2.0 \mathrm{~Hz}, 1 \mathrm{H}), 8.31(\mathrm{~s}, 1 \mathrm{H}), 8.27(\mathrm{~d}, J=5.0 \mathrm{~Hz}, 1 \mathrm{H}), 7.66(\mathrm{~d}, J$ $=8.0 \mathrm{~Hz}, 1 \mathrm{H}), 7.63(\mathrm{~d}, J=9.0 \mathrm{~Hz}, 2 \mathrm{H}), 7.414(\mathrm{t}, J=8.0 \mathrm{~Hz}, 1 \mathrm{H})$, $7.36-7.32(\mathrm{~m}, 2 \mathrm{H}), 7.20(\mathrm{dd}, J=9.0,4.5 \mathrm{~Hz}, 1 \mathrm{H}), 7.00(\mathrm{~d}, J=9.0$ $\mathrm{Hz}, 2 \mathrm{H}), 6.76(\mathrm{~d}, J=5.5 \mathrm{~Hz}, 1 \mathrm{H}), 3.89(\mathrm{~s}, 3 \mathrm{H})$. LC-MS $(\mathrm{m} / z)$ : $420.0[\mathrm{M}+\mathrm{H}]^{+}$.

3-((4-(2-(4-(Trifluoromethyl)phenyl)pyrazolo [1,5-b]pyridazin-3-yl)pyrimidin-2-yl)amino)benzonitrile (21b). In a vial $7 \mathrm{~d}$ (15 mg, $40 \mu \mathrm{mol}$ ), cesium carbonate (39 mg, $120 \mu \mathrm{mol}$ ), 3aminobenzonitrile $(9 \mathrm{mg}, 80 \mu \mathrm{mol})$, palladium(II) acetate $(0.5 \mathrm{mg}$, $4.0 \mu \mathrm{mol})$, and Xantphos $(2.3 \mathrm{mg}, 4 \mu \mathrm{mol})$ were added in $1.5 \mathrm{~mL}$ of anhydrous dioxane. The reaction mixture was sealed then evacuated and backfilled with $\mathrm{N}_{2}$ three times. The reaction mixture was then subjected to microwave irradiation at $160{ }^{\circ} \mathrm{C}$ for $1 \mathrm{~h}$. The reaction was filtered through Celite and washed with EtOAc, then evaporated to dryness. Column purification was performed using EtOAc/hexanes $25-100 \%$, to yield the title compound as a pale-yellow solid $(11.7 \mathrm{mg}$, 64\%). ${ }^{1} \mathrm{H}$ NMR (500 MHz, DMSO- $d_{6}$ ) $\delta$ ppm 10.06 (s, $1 \mathrm{H}$ ), 8.80$8.85(\mathrm{~m}, 1 \mathrm{H}), 8.69(\mathrm{dd}, J=4.4,2.0 \mathrm{~Hz}, 1 \mathrm{H}), 8.50(\mathrm{~d}, J=5.4 \mathrm{~Hz}, 1$ H), $8.19(\mathrm{~s}, 1 \mathrm{H}), 7.89$ (d, $J=8.3 \mathrm{~Hz}, 2 \mathrm{H}), 7.82-7.87(\mathrm{~m}, 3 \mathrm{H}), 7.49$ $(\mathrm{dd}, J=8.8,4.4 \mathrm{~Hz}, 1 \mathrm{H}), 7.41(\mathrm{t}, J=7.8 \mathrm{~Hz}, 1 \mathrm{H}), 7.36(\mathrm{~d}, J=7.8$ $\mathrm{Hz}, 1 \mathrm{H}), 6.79(\mathrm{~d}, J=5.37 \mathrm{~Hz}, 1 \mathrm{H}) . \mathrm{LC}-\mathrm{MS}(\mathrm{m} / z): 458.1[\mathrm{M}+$ $\mathrm{H}]^{+}$.

3-((4-(2-(2-Hydroxypropan-2-yl)pyrazolo[1,5-b]pyridazin-3yl)pyrimidin-2-yl)amino)benzonitrile (21c). In a vial $7 \mathrm{~g}(71 \mathrm{mg}$, $170 \mu \mathrm{mol})$, and 3 -aminobenzonitrile $(87 \mathrm{mg}, 740 \mu \mathrm{mol})$ were stirred in $n-\mathrm{BuOH}(2 \mathrm{~mL})$ and the reaction mixture was subjected to microwave irradiation at $150{ }^{\circ} \mathrm{C}$ for $2 \mathrm{~h}$. After completion of reaction mixture was evaporated to dryness and column purification was done using $\mathrm{MeOH} / \mathrm{DCM} 0-5 \%$, followed by column purification $25-$ $100 \% \mathrm{EtOAc} / \mathrm{hexanes}$, followed by preparative reverse phase HPLC purification $30-100 \% \mathrm{ACN} /$ water, affording the title compound as a white solid $(2.9 \mathrm{mg}, 4 \%) .{ }^{1} \mathrm{H}$ NMR $\left(500 \mathrm{MHz}\right.$, methanol- $\left.d_{4}\right) \delta \mathrm{ppm}$ 8.54-8.60 (m, $2 \mathrm{H}), 8.47(\mathrm{dd}, J=4.4,1.5 \mathrm{~Hz}, 1 \mathrm{H}), 8.26(\mathrm{~s}, 1 \mathrm{H})$, $7.89(\mathrm{~d}, J=8.3 \mathrm{~Hz}, 1 \mathrm{H}), 7.51(\mathrm{~d}, J=5.4 \mathrm{~Hz}, 1 \mathrm{H}), 7.47(\mathrm{t}, J=8.3 \mathrm{~Hz}$, $1 \mathrm{H}), 7.31-7.38(\mathrm{~m}, 2 \mathrm{H}), 1.69(\mathrm{~s}, 6 \mathrm{H})$. LC-MS $(\mathrm{m} / z): 372.1[\mathrm{M}+$ $\mathrm{H}]^{+}$.

3-((4-(2-(Hydroxymethyl)pyrazolo[1,5-b]pyridazin-3-yl)pyrimidin-2-yl)amino)benzonitrile (21d). In a vial $7 \mathrm{~h}(33.5 \mathrm{mg}$, $128 \mu \mathrm{mol})$ and 3 -aminobenzonitrile $(37.8 \mathrm{mg}, 320 \mu \mathrm{mol})$ were stirred in $n-\mathrm{BuOH}(2 \mathrm{~mL})$ and subjected to microwave irradiation at $150{ }^{\circ} \mathrm{C}$ for $1 \mathrm{~h}$. The reaction mixture was filtered, and the precipitate was washed with $\mathrm{MeOH}$. The precipitate was found to contain the desired product as a brown solid ( $8 \mathrm{mg}, 18 \%) .{ }^{1} \mathrm{H}$ NMR $(500 \mathrm{MHz}$, DMSO$\left.d_{6}\right) \delta \mathrm{ppm} 9.96(\mathrm{~s}, 1 \mathrm{H}), 9.02-9.09(\mathrm{~m}, 1 \mathrm{H}), 8.58-8.64(\mathrm{~m}, 2 \mathrm{H})$, $8.38(\mathrm{~s}, 1 \mathrm{H}), 7.96(\mathrm{dd}, J=8.3,2.0 \mathrm{~Hz}, 1 \mathrm{H}), 7.49-7.56(\mathrm{~m}, 2 \mathrm{H})$, 7.40-7.47 (m, $2 \mathrm{H}), 5.64$ (br s, $1 \mathrm{H}), 4.87(\mathrm{~s}, 2 \mathrm{H})$. LC-MS $(\mathrm{m} / \mathrm{z})$ : $344.2[\mathrm{M}+\mathrm{H}]^{+}$.

3-((4-(2-(Methoxymethyl)pyrazolo[1,5-b]pyridazin-3-yl)pyrimidin-2-yl)amino)benzonitrile (21e). In a vial were added $7 \mathrm{i}$ $(100 \mathrm{mg}, 362 \mu \mathrm{mol})$ and 3-aminobenzonitrile $(85.7 \mathrm{mg}, 725 \mu \mathrm{mol})$ with $1.5 \mathrm{~mL}$ of $n-\mathrm{BuOH}$. The reaction mixture was subjected to microwave irradiation at $150{ }^{\circ} \mathrm{C}$ for $2 \mathrm{~h}$. The reaction was cooled to room temperature, filtered, and washed with diethyl ether to yield the desired product in the precipitate as an off-white solid $(116.8 \mathrm{mg}$, 90\%). ${ }^{1} \mathrm{H}$ NMR (500 MHz, DMSO- $\left.d_{6}\right) \delta$ ppm 9.98 (s, $1 \mathrm{H}$ ), 9.03$9.09(\mathrm{~m}, 1 \mathrm{H}), 8.65(\mathrm{dd}, J=4.4,2.0 \mathrm{~Hz}, 1 \mathrm{H}), 8.62(\mathrm{~d}, J=5.4 \mathrm{~Hz}, 1$ H), $8.38(\mathrm{~s}, 1 \mathrm{H}), 7.94-7.99(\mathrm{~m}, 1 \mathrm{H}), 7.53(\mathrm{t}, J=8.1 \mathrm{~Hz}, 1 \mathrm{H}), 7.46$ $(\mathrm{dd}, J=8.8,4.4 \mathrm{~Hz}, 1 \mathrm{H}), 7.42(\mathrm{~d}, J=7.3 \mathrm{~Hz}, 1 \mathrm{H}), 7.33(\mathrm{~d}, J=5.4$ $\mathrm{Hz}, 1 \mathrm{H}), 4.84(\mathrm{~s}, 2 \mathrm{H}), 3.37(\mathrm{~s}, 3 \mathrm{H})$. LC-MS $(\mathrm{m} / z): 358.1[\mathrm{M}+$ $\mathrm{H}]^{+}$.

3-((4-(2-(1-Hydroxyethyl)pyrazolo[1,5-b]pyridazin-3-yl)pyrimidin-2-yl)amino)benzonitrile (21f). In a vial were added $7 \mathrm{j}$
(100 mg, $363 \mu \mathrm{mol}$ ) and 3-aminobenzonitrile (86 mg, $725 \mu \mathrm{mol}$ ) with $1.5 \mathrm{~mL}$ of $n-\mathrm{BuOH}$. The reaction mixture was subjected to microwave irradiation at $150{ }^{\circ} \mathrm{C}$ for $2 \mathrm{~h}$. The reaction was then concentrated in vacuo. Column purification was performed using EtOAc/hex $45-100 \%$ to afford the title compound as a white solid (95.5 mg, 74\%). ${ }^{1} \mathrm{H}$ NMR (500 MHz, DMSO- $\left.d_{6}\right) \delta$ ppm 9.96 (s, 1 $\mathrm{H}), 8.93(\mathrm{~d}, J=8.8 \mathrm{~Hz}, 1 \mathrm{H}), 8.58-8.63(\mathrm{~m}, 2 \mathrm{H}), 8.38(\mathrm{~s}, 1 \mathrm{H}), 7.97$ $(\mathrm{d}, J=8.3 \mathrm{~Hz}, 1 \mathrm{H}), 7.59(\mathrm{~d}, J=5.4 \mathrm{~Hz}, 1 \mathrm{H}), 7.51(\mathrm{t}, J=8.3 \mathrm{~Hz}, 1$ $\mathrm{H}$ ), 7.39-7.44 (m, $2 \mathrm{H}$ ), $5.63(\mathrm{~d}, J=6.4 \mathrm{~Hz}, 1 \mathrm{H}$ ), 5.28 (quin, $J=6.4$ $\mathrm{Hz}, 1 \mathrm{H}), 1.62(\mathrm{~d}, J=6.4 \mathrm{~Hz}, 3 \mathrm{H})$. LC-MS $(\mathrm{m} / z): 358.1[\mathrm{M}+\mathrm{H}]^{+}$. 3-((4-(2-Isopropylpyrazolo[1,5-b]pyridazin-3-yl)pyrimidin2-yl)amino)benzonitrile (21g). In a vial $7 \mathrm{k}(100 \mathrm{mg}, 365 \mu \mathrm{mol})$ and 3-aminobenzonitrile ( $86 \mathrm{mg}, 731 \mu \mathrm{mol}$ ) were stirred in $1.5 \mathrm{~mL}$ of $n-\mathrm{BuOH}$. The reaction mixture was subjected to microwave irradiation and heated to $150{ }^{\circ} \mathrm{C}$ for $2 \mathrm{~h}$. The reaction mixture was concentrated in vacuo. Column purification was performed using 1$5 \% \mathrm{MeOH}$ in DCM, followed by reverse phase preparative HPLC purification using $\mathrm{ACN} /$ water $5-95 \%$ with $0.1 \%$ formic acid, providing the title compound as a tan solid $(36.8 \mathrm{mg}, 28 \%) .{ }^{1} \mathrm{H}$ NMR $\left(500 \mathrm{MHz}\right.$, DMSO- $\left.d_{6}\right) \delta \mathrm{ppm} 9.98(\mathrm{~s}, 1 \mathrm{H}), 8.75-8.82(\mathrm{~m}, 1$ $\mathrm{H}), 8.59(\mathrm{~d}, J=5.4 \mathrm{~Hz}, 1 \mathrm{H}), 8.55(\mathrm{~d}, J=4.4 \mathrm{~Hz}, 1 \mathrm{H}), 8.37(\mathrm{~s}, 1 \mathrm{H})$, $7.97(\mathrm{~d}, J=8.3 \mathrm{~Hz}, 1 \mathrm{H}), 7.51(\mathrm{t}, J=8.3 \mathrm{~Hz}, 1 \mathrm{H}), 7.37-7.43(\mathrm{~m}, 2$ $\mathrm{H}), 7.20(\mathrm{~d}, J=5.4 \mathrm{~Hz}, 1 \mathrm{H}), 3.79(\mathrm{spt}, J=6.8 \mathrm{~Hz}, 1 \mathrm{H}), 1.38(\mathrm{~d}, J=$ $6.8 \mathrm{~Hz}, 6 \mathrm{H})$. LC-MS $(\mathrm{m} / z): 356.1[\mathrm{M}+\mathrm{H}]^{+}$.

3-((4-(2-Cyclopropylpyrazolo[ $1,5-b]$ pyridazin-3-yl)pyrimidin-2-yl)amino)benzonitrile $(21 \mathrm{~h})$. In a vial $7 \mathrm{e}(100 \mathrm{mg}$, $368 \mu \mathrm{mol}$ ) and 3-aminobenzonitrile ( $87 \mathrm{mg}, 736 \mu \mathrm{mol})$ were stirred in $1.5 \mathrm{~mL}$ of $n-\mathrm{BuOH}$. The reaction mixture was subjected to microwave irradiation at $150{ }^{\circ} \mathrm{C}$ for $2 \mathrm{~h}$. The reaction was filtered and washed with diethyl ether to give the crude product in the precipitate. Column purification was performed using $\mathrm{MeOH} / \mathrm{DCM} 0-3 \%$ followed by reverse phase purification using ACN/water 5-95\% with $0.1 \%$ formic acid to afford the title compound as a white solid (46.1 mg, 35\%). ${ }^{1} \mathrm{H}$ NMR (500 MHz, chloroform- $d$ ) $\delta$ ppm 8.68 (dd, $J=8.8,2.0 \mathrm{~Hz}, 1 \mathrm{H}), 8.52(\mathrm{~d}, J=5.4 \mathrm{~Hz}, 1 \mathrm{H}), 8.34-8.35(\mathrm{~m}, 1 \mathrm{H})$, $8.33(\mathrm{dd}, J=4.4,2.0 \mathrm{~Hz}, 1 \mathrm{H}), 7.65-7.70(\mathrm{~m}, 1 \mathrm{H}), 7.41-7.45(\mathrm{~m}, 3$ $\mathrm{H}), 7.34(\mathrm{~d}, J=7.8 \mathrm{~Hz}, 1 \mathrm{H}), 7.16(\mathrm{dd}, J=8.8,4.4 \mathrm{~Hz}, 1 \mathrm{H}), 2.31-$ $2.39(\mathrm{~m}, 1 \mathrm{H}), 1.30-1.35(\mathrm{~m}, 2 \mathrm{H}), 1.15-1.20(\mathrm{~m}, 2 \mathrm{H})$. LC-MS $(m / z): 354.1[\mathrm{M}+\mathrm{H}]^{+}$.

4-(6-Morpholinopyrazolo[1,5-b]pyridazin-3-yl)- N-phenylpyrimidin-2-amine (22a). In a reaction vial were added $7 \mathbf{b}(20 \mathrm{mg}$, $63 \mu \mathrm{mol})$ and aniline $(12 \mu \mathrm{L}, 126 \mu \mathrm{mol})$ in $n-\mathrm{BuOH}(1 \mathrm{~mL})$, the reaction mixture was subjected to microwave irradiation at $150{ }^{\circ} \mathrm{C}$ for $1 \mathrm{~h}$. Then the reaction mixture was evaporated to dryness and column purification done using EtOAc/hex 50-100\% $12 \mathrm{CV}$ followed by EtOAc/MeOH $1-20 \% 5 \mathrm{CV}$ to afford the title compound as a yellow/brown solid (10 mg, 42\%). ${ }^{1} \mathrm{H}$ NMR ( $500 \mathrm{MHz}$, chloroformd) $\delta \mathrm{ppm} 8.65(\mathrm{~d}, J=9.8 \mathrm{~Hz}, 1 \mathrm{H}), 8.37(\mathrm{~d}, J=5.4 \mathrm{~Hz}, 1 \mathrm{H}), 8.26(\mathrm{~s}$, $1 \mathrm{H}), 7.62(\mathrm{~d}, J=7.8 \mathrm{~Hz}, 2 \mathrm{H}), 7.38(\mathrm{t}, J=7.8 \mathrm{~Hz}, 2 \mathrm{H}), 7.25(\mathrm{br} \mathrm{s}, 1$ $\mathrm{H}), 7.11(\mathrm{t}, J=7.8 \mathrm{~Hz}, 1 \mathrm{H}), 7.02(\mathrm{~d}, J=5.4 \mathrm{~Hz}, 1 \mathrm{H}), 6.87(\mathrm{~d}, J=9.8$ $\mathrm{Hz}, 1 \mathrm{H}), 3.86(\mathrm{t}, J=4.4 \mathrm{~Hz}, 4 \mathrm{H}), 3.59(\mathrm{t}, J=4.4 \mathrm{~Hz}, 4 \mathrm{H})$. LC-MS $(\mathrm{m} / z): 374.0[\mathrm{M}+\mathrm{H}]^{+}$.

$\mathrm{N}$-(3-Methoxyphenyl)-4-(6-morpholinopyrazolo[1,5-b]pyridazin-3-yl)pyrimidin-2-amine (22b). In a vial $7 \mathbf{b}(0.020 \mathrm{~g}$, $63.14 \mu \mathrm{mol})$ and $m$-anisidine $(15 \mu \mathrm{L}, 126 \mu \mathrm{mol})$ were stirred in $n$ $\mathrm{BuOH}$. The reaction mixture was subjected to microwave irradiation at $150{ }^{\circ} \mathrm{C}$ for $1 \mathrm{~h}$. On cooling solid precipitation seen, which was filtered and washed with diethyl ether and air-dried to afford the title compound as a dark brown solid (14 mg, 55\%). ${ }^{1} \mathrm{H}$ NMR $(500 \mathrm{MHz}$, chloroform- $d) \delta \mathrm{ppm} 8.70(\mathrm{~d}, J=9.8 \mathrm{~Hz}, 1 \mathrm{H}), 8.38(\mathrm{~d}, J=5.4 \mathrm{~Hz}, 1$ $\mathrm{H}), 8.27(\mathrm{~s}, 1 \mathrm{H}), 7.36(\mathrm{t}, J=2.4 \mathrm{~Hz}, 1 \mathrm{H}), 7.27-7.31(\mathrm{~m}, 1 \mathrm{H})$, $7.10-7.15(\mathrm{~m}, 2 \mathrm{H}), 7.03(\mathrm{~d}, J=5.4 \mathrm{~Hz}, 1 \mathrm{H}), 6.89(\mathrm{~d}, J=9.8 \mathrm{~Hz}, 1$ $\mathrm{H}), 6.66(\mathrm{dd}, J=8.3,2.4 \mathrm{~Hz}, 1 \mathrm{H}), 3.87(\mathrm{t}, J=4.9 \mathrm{~Hz}, 4 \mathrm{H}), 3.83(\mathrm{~s}, 3$ $\mathrm{H}), 3.60(\mathrm{t}, J=4.9 \mathrm{~Hz}, 4 \mathrm{H})$. LC-MS $(\mathrm{m} / z): 404.0[\mathrm{M}+\mathrm{H}]^{+}$.

3-((4-(6-Morpholinopyrazolo[ $1,5-b]$ pyridazin-3-yl)pyrimidin-2-yl)amino)benzonitrile (22c). In a vial $7 \mathrm{~b}(20 \mathrm{mg}, 63$ $\mu \mathrm{mol}), \mathrm{K}_{3} \mathrm{PO}_{4}(27 \mathrm{mg}, 126 \mu \mathrm{mol})$, XPhos (5 mg, $9.5 \mu \mathrm{mol}$ ), tris(dibenzylideneacetone)palladium( 0$)(3 \mathrm{mg}, 3.2 \mu \mathrm{mol})$, and $\mathrm{m}$ aminobenzonitrile $(15 \mathrm{mg}, 126 \mu \mathrm{mol})$ were added. The vial was sealed with a stir bar and then evacuated and backfilled with $\mathrm{N}_{2}$ three 
times, $1 \mathrm{~mL}$ of $n-\mathrm{BuOH}$ was added to a sealed vial. The reaction was left stirring at $101{ }^{\circ} \mathrm{C}$ for $16 \mathrm{~h}$. Solid precipitation was seen in the reaction vial, which was filtered and washed with diethyl ether. Column purification was undertaken on the precipitate using EtOAc/ hex $70-100 \% 5 \mathrm{CV}$ followed by $\mathrm{MeOH} / \mathrm{EtOAc} 1-20 \% 10 \mathrm{CV}$ to afford the title compound as a white solid $(6.3 \mathrm{mg}, 25 \%) .{ }^{1} \mathrm{H}$ NMR $(500 \mathrm{MHz}$, chloroform- $d$ ) $\delta$ ppm $8.68(\mathrm{~d}, J=9.8 \mathrm{~Hz}, 1 \mathrm{H}), 8.39-8.45$ $(\mathrm{m}, 2 \mathrm{H}), 8.28(\mathrm{~s}, 1 \mathrm{H}), 7.56(\mathrm{ddd}, J=7.8,2.4,1.0 \mathrm{~Hz}, 1 \mathrm{H}), 7.45(\mathrm{t}, J$ $=7.8 \mathrm{~Hz}, 1 \mathrm{H}), 7.36(\mathrm{dt}, J=7.8,1.0 \mathrm{~Hz}, 1 \mathrm{H}), 7.32(\mathrm{br} \mathrm{s}, 1 \mathrm{H}), 7.12$ $(\mathrm{d}, J=5.4 \mathrm{~Hz}, 1 \mathrm{H}), 7.06(\mathrm{~d}, J=9.8 \mathrm{~Hz}, 1 \mathrm{H}), 3.87(\mathrm{t}, J=4.9 \mathrm{~Hz}, 4$ H), $3.61(\mathrm{t}, J=4.9 \mathrm{~Hz}, 4 \mathrm{H})$. LC-MS $(\mathrm{m} / z): 399.0[\mathrm{M}+\mathrm{H}]^{+}$.

3-((4-(6-Methoxypyrazolo[1,5-b]pyridazin-3-yl)pyrimidin-2yl)amino)benzonitrile (22d). In a vial 3- $7 \mathrm{c}(15 \mathrm{mg}, 57 \mu \mathrm{mol})$ and 3 -aminobenzonitrile $(34 \mathrm{mg}, 287 \mu \mathrm{mol})$ were stirred in $n$-BuOH $(1.5$ $\mathrm{mL}$ ) and subjected to microwave irradiation at $150{ }^{\circ} \mathrm{C}$ for $2 \mathrm{~h}$. The reaction mixture was then heated to $110{ }^{\circ} \mathrm{C}$ using conventional heating for an additional $96 \mathrm{~h}$. The mixture was then concentrated, and column purification was undertaken using EtOAc/hex, 25-33\% to yield the title compound as a white solid $(7.0 \mathrm{mg}, 37 \%) .{ }^{1} \mathrm{H}$ NMR $(500 \mathrm{MHz}$, chloroform- $d) \delta \mathrm{ppm} 8.74(\mathrm{~d}, J=9.8 \mathrm{~Hz}, 1 \mathrm{H}), 8.45$ (d, $J$ $=5.4 \mathrm{~Hz}, 1 \mathrm{H}), 8.32-8.36(\mathrm{~m}, 2 \mathrm{H}), 7.62-7.67(\mathrm{~m}, 1 \mathrm{H}), 7.45(\mathrm{t}, J=$ $7.8 \mathrm{~Hz}, 1 \mathrm{H}), 7.36(\mathrm{~d}, J=7.8 \mathrm{~Hz}, 1 \mathrm{H}), 7.20(\mathrm{br} \mathrm{s}, 1 \mathrm{H}), 7.14(\mathrm{~d}, J=$ $5.4 \mathrm{~Hz}, 1 \mathrm{H}), 6.95(\mathrm{~d}, J=9.8 \mathrm{~Hz}, 1 \mathrm{H}), 4.11(\mathrm{~s}, 3 \mathrm{H})$. LC-MS $(\mathrm{m} / z)$ : $344.1[\mathrm{M}+\mathrm{H}]^{+}$.

3-((4-(2-(Hydroxymethyl)-6-methoxypyrazolo[1,5-b]pyridazin-3-yl)pyrimidin-2-yl)amino)benzonitrile (23a). In a vial $71(20 \mathrm{mg}, 69 \mu \mathrm{mol})$ and 3-aminobenzonitrile $(24 \mathrm{mg}, 206 \mu \mathrm{mol})$ were added to $n$ - $\mathrm{BuOH}(1 \mathrm{~mL})$, and the reaction was heated to 150 ${ }^{\circ} \mathrm{C}$ for $2 \mathrm{~h}$, then $180^{\circ} \mathrm{C}$ for $3 \mathrm{~h}$. The reaction was filtered and washed with diethyl ether to yield the desired product in the precipitate as a white solid $(7.2 \mathrm{mg}, 28 \%) .{ }^{1} \mathrm{H}$ NMR (400 MHz, DMSO- $\left.d_{6}\right) \delta$ ppm $9.96(\mathrm{~s}, 1 \mathrm{H}), 8.93(\mathrm{~d}, J=9.5 \mathrm{~Hz}, 1 \mathrm{H}), 8.59(\mathrm{~d}, J=5.1 \mathrm{~Hz}, 1 \mathrm{H}), 8.38$ $(\mathrm{t}, J=1.5 \mathrm{~Hz}, 1 \mathrm{H}), 7.93-7.98(\mathrm{~m}, 1 \mathrm{H}), 7.47-7.56(\mathrm{~m}, 2 \mathrm{H}), 7.41$ $(\mathrm{dt}, J=7.3,1.5 \mathrm{~Hz}, 1 \mathrm{H}), 7.14(\mathrm{~d}, J=9.5 \mathrm{~Hz}, 1 \mathrm{H}), 5.59(\mathrm{t}, J=5.1 \mathrm{~Hz}$ $1 \mathrm{H}), 4.80(\mathrm{~d}, J=5.1 \mathrm{~Hz}, 2 \mathrm{H}), 4.00(\mathrm{~s}, 3 \mathrm{H}) . \mathrm{LC}-\mathrm{MS}(\mathrm{m} / z): 374.1$ $[\mathrm{M}+\mathrm{H}]^{+}$

3-((4-(2-(Hydroxymethyl)-6-morpholinopyrazolo[1,5-b]pyridazin-3-yl)pyrimidin-2-yl)amino)benzonitrile (23b). In a vial $7 \mathrm{~m}(30 \mathrm{mg}, 87 \mu \mathrm{mol})$ and 3-aminobenzonitrile $(20 \mathrm{mg}, 173$ $\mu \mathrm{mol}$ ) were stirred in $1.5 \mathrm{~mL}$ of $n-\mathrm{BuOH}$, and the reaction was subjected to microwave irradiation at $150{ }^{\circ} \mathrm{C}$ for $3 \mathrm{~h}$. The reaction was filtered and washed with diethyl ether to give the crude product in the precipitate. Column purification was undertaken using $\mathrm{MeOH} /$ DCM $2-30 \%$ to afford the title compound as a white solid $(20.8 \mathrm{mg}$, $56 \%) .{ }^{1} \mathrm{H}$ NMR ( $\left.500 \mathrm{MHz}, \mathrm{DMSO}-d_{6}\right) \delta \mathrm{ppm} 9.94(\mathrm{~s}, 1 \mathrm{H}), 8.76(\mathrm{~d}$, $J=9.8 \mathrm{~Hz}, 1 \mathrm{H}), 8.56(\mathrm{~d}, J=5.4 \mathrm{~Hz}, 1 \mathrm{H}), 8.36(\mathrm{~s}, 1 \mathrm{H}), 7.95-7.99$ $(\mathrm{m}, 1 \mathrm{H}), 7.53(\mathrm{t}, J=8.3 \mathrm{~Hz}, 1 \mathrm{H}), 7.46(\mathrm{~d}, J=5.4 \mathrm{~Hz}, 1 \mathrm{H}), 7.36-$ $7.42(\mathrm{~m}, 2 \mathrm{H}), 5.52(\mathrm{t}, J=4.9 \mathrm{~Hz}, 1 \mathrm{H}), 4.76(\mathrm{~d}, J=4.9 \mathrm{~Hz}, 2 \mathrm{H})$, $3.76(\mathrm{t}, J=4.9 \mathrm{~Hz}, 4 \mathrm{H}), 3.52(\mathrm{t}, J=4.9 \mathrm{~Hz}, 4 \mathrm{H})$. LC-MS $(\mathrm{m} / z)$ : $429.1[\mathrm{M}+\mathrm{H}]^{+}$.

3-((4-(2-Cyclopropyl-6-morpholinopyrazolo[ 1,5-b]pyridazin-3-yl)pyrimidin-2-yl)amino)benzonitrile (23c). In a vial 7 o $(25 \mathrm{mg}, 70 \mu \mathrm{mol})$, cesium carbonate (69 mg, $220 \mu \mathrm{mol})$, 3aminopyridine (17 mg, $140 \mu \mathrm{mol}$ ), palladium(II) acetate $(0.8 \mathrm{mg}, 3.5$ $\mu \mathrm{mol})$, and Xantphos $(4.1 \mathrm{mg}, 7.0 \mu \mathrm{mol})$ were stirred in anhydrous dioxane $(2 \mathrm{~mL})$, the reaction mixture was sealed then evacuated and backfilled with $\mathrm{N}_{2}$ three times. The reaction mixture was then subjected to microwave irradiation at $160{ }^{\circ} \mathrm{C}$ for $1 \mathrm{~h}$. The reaction was filtered through Celite and washed with EtOAc, then evaporated to dryness. Column purification was performed using EtOAc/hex 25$75 \%$, to afford the title compound as an orange solid $(21.5 \mathrm{mg}, 70 \%)$. ${ }^{1} \mathrm{H}$ NMR $(500 \mathrm{MHz}$, chloroform- $d) \delta \mathrm{ppm} 8.51(\mathrm{~d}, J=9.8 \mathrm{~Hz}, 1 \mathrm{H})$, $8.46(\mathrm{~d}, J=5.4 \mathrm{~Hz}, 1 \mathrm{H}), 8.39(\mathrm{~s}, 1 \mathrm{H}), 7.62(\mathrm{dd}, J=8.3,2.0 \mathrm{~Hz}, 1$ H), 7.40-7.49 (m, $2 \mathrm{H}), 7.34(\mathrm{~d}, J=7.8 \mathrm{~Hz}, 1 \mathrm{H}), 7.22-7.25(\mathrm{~s}, 1$ $\mathrm{H}), 6.95(\mathrm{~d}, J=9.8 \mathrm{~Hz}, 1 \mathrm{H}), 3.85(\mathrm{t}, J=4.4 \mathrm{~Hz}, 4 \mathrm{H}), 3.57(\mathrm{t}, J=5.4$ $\mathrm{Hz}, 4 \mathrm{H}), 2.22-2.29(\mathrm{~m}, 1 \mathrm{H}), 1.23-1.28(\mathrm{~m}, 2 \mathrm{H}), 1.08-1.14(\mathrm{~m}, 2$ H) LC-MS $(m / z): 439.1[\mathrm{M}+\mathrm{H}]^{+}$.

4-(2-Cyclopropylpyrazolo[1,5-b]pyridazin-3-yl)- $\mathrm{N}$-(pyridin3-yl)pyrimidin-2-amine (23d). In a vial 3-(2-chloropyrimidin-4-yl)2-cyclopropylpyrazolo[1,5-b]pyridazine 7 e $(30 \mathrm{mg}, 110 \mu \mathrm{mol})$, cesium carbonate $(108 \mathrm{mg}, 331 \mu \mathrm{mol}), 3$-aminopyridine $(21 \mathrm{mg}$ $220 \mu \mathrm{mol})$, palladium(II) acetate $(1.2 \mathrm{mg}, 5.5 \mu \mathrm{mol})$, and Xantphos $(6.4 \mathrm{mg}, 11 \mu \mathrm{mol})$ were stirred in anhydrous dioxane $(1.5 \mathrm{~mL})$, the reaction mixture was sealed then evacuated and backfilled with $\mathrm{N}_{2}$ three times. The reaction mixture was then subjected to microwave irradiation at $160{ }^{\circ} \mathrm{C}$ for $1 \mathrm{~h}$. The reaction was filtered through Celite and washed with EtOAc, then evaporated to dryness. Reverse phase column purification was done using ACN/water 5-95\% with $0.1 \%$ formic acid, to afford the title compound as a white solid $(17.0 \mathrm{mg}$, 47\%). ${ }^{1} \mathrm{H}$ NMR ( $500 \mathrm{MHz}$, methanol- $\left.d_{4}\right) \delta \mathrm{ppm} 8.92(\mathrm{~d}, J=2.4 \mathrm{~Hz}$, $1 \mathrm{H}), 8.89(\mathrm{dd}, J=8.8,2.0 \mathrm{~Hz}, 1 \mathrm{H}), 8.52(\mathrm{~d}, J=5.4 \mathrm{~Hz}, 1 \mathrm{H}), 8.40$ (dd, $J=4.4,2.0 \mathrm{~Hz}, 1 \mathrm{H}$ ), 8.32 (ddd, $J=8.3,2.4,1.5 \mathrm{~Hz}, 1 \mathrm{H}$ ), 8.17 $(\mathrm{dd}, J=4.6,1.5 \mathrm{~Hz}, 1 \mathrm{H}), 7.47(\mathrm{~d}, J=5.4 \mathrm{~Hz}, 1 \mathrm{H}), 7.39(\mathrm{dd}, J=8.3$, $4.6 \mathrm{~Hz}, 1 \mathrm{H}), 7.28(\mathrm{dd}, J=8.8,4.4 \mathrm{~Hz}, 1 \mathrm{H}), 2.45-2.53(\mathrm{~m}, 1 \mathrm{H})$, $1.11-1.23(\mathrm{~m}, 4 \mathrm{H})$. LC-MS $(\mathrm{m} / z): 330.1[\mathrm{M}+\mathrm{H}]^{+}$.

4-(6-Methoxypyrazolo[1,5-b]pyridazin-3-yl)- $\mathrm{N}$-(pyridin-3yl)pyrimidin-2-amine (23e). In a vial $7 \mathrm{c}(30 \mathrm{mg}$, $115 \mu \mathrm{mol})$, cesium carbonate $(112 \mathrm{mg}, 344 \mu \mathrm{mol}), 3$-aminopyridine $(22 \mathrm{mg}, 230$ $\mu \mathrm{mol})$, palladium(II) acetate $(1.3 \mathrm{mg}, 5.7 \mu \mathrm{mol})$, and Xantphos $(6.6$ $\mathrm{mg}, 12 \mu \mathrm{mol})$ were stirred in anhydrous dioxane $(1.5 \mathrm{~mL})$. The reaction mixture was sealed then evacuated and backfilled with $\mathrm{N}_{2}$ three times. The reaction mixture was then subjected to microwave irradiation at $160{ }^{\circ} \mathrm{C}$ for $1 \mathrm{~h}$. The reaction was filtered through Celite and washed with $\mathrm{MeOH}$, then evaporated to dryness. Reverse phase column purification was performed $\mathrm{ACN} /$ water $5-95 \%$ with $0.1 \%$ formic acid, affording the title compound as a yellow solid $(10.3 \mathrm{mg}$, 28\%). ${ }^{1} \mathrm{H}$ NMR (500 MHz, DMSO- $\left.d_{6}\right) \delta \mathrm{ppm} 9.75(\mathrm{~s}, 1 \mathrm{H}), 9.00(\mathrm{~d}$, $J=9.8 \mathrm{~Hz}, 1 \mathrm{H}), 8.88(\mathrm{~d}, J=2.9 \mathrm{~Hz}, 1 \mathrm{H}), 8.71(\mathrm{~s}, 1 \mathrm{H}), 8.49(\mathrm{~d}, J=$ $5.4 \mathrm{~Hz}, 1 \mathrm{H}$ ), 8.23 (ddd, $J=8.3,2.9,1.5 \mathrm{~Hz}, 1 \mathrm{H}), 8.19$ (dd, $J=4.9$, $1.5 \mathrm{~Hz}, 1 \mathrm{H}), 7.39(\mathrm{~d}, J=5.4 \mathrm{~Hz}, 1 \mathrm{H}), 7.36(\mathrm{dd}, J=8.3,4.9 \mathrm{~Hz}, 1$ H), $7.18(\mathrm{~d}, J=9.8 \mathrm{~Hz}, 1 \mathrm{H}), 4.02(\mathrm{~s}, 3 \mathrm{H})$. LC-MS $(\mathrm{m} / \mathrm{z}): 320.1$ $[\mathrm{M}+\mathrm{H}]^{+}$.

(6-Methoxy-3-(2-(pyridin-3-ylamino)pyrimidin-4-yl)pyrazolo[1,5-b]pyridazin-2-yl)methanol (23f). In a vial 71 (30 $\mathrm{mg}, 103 \mu \mathrm{mol})$, cesium carbonate $(101 \mathrm{mg}, 309 \mu \mathrm{mol})$, 3aminopyridine (19.4 mg, $206 \mu \mathrm{mol})$, palladium(II) acetate $(1.2 \mathrm{mg}$, $8.2 \mu \mathrm{mol})$, and Xantphos $(6.0 \mathrm{mg}, 10.3 \mu \mathrm{mol})$ were stirred in anhydrous dioxane $(1.5 \mathrm{~mL})$. The reaction mixture was sealed then evacuated and backfilled with nitrogen $3 \times$. The reaction mixture was then subjected to $\mathrm{MW}$ irradiation at $160{ }^{\circ} \mathrm{C}$ for $1.5 \mathrm{~h}$. The reaction was filtered through Celite and washed with $\mathrm{MeOH}$, then evaporated to dryness. Reverse phase column purification was performed ACN/ water $5-95 \%$ with $0.1 \%$ formic acid, to afford the title compound as a yellow solid (15.5 mg, 43\%). ${ }^{1} \mathrm{H}$ NMR (500 MHz, DMSO- $\left.d_{6}\right) \delta \mathrm{ppm}$ $9.75(\mathrm{~s}, 1 \mathrm{H}), 8.92(\mathrm{~d}, J=9.8 \mathrm{~Hz}, 1 \mathrm{H}), 8.88(\mathrm{~d}, J=2.4 \mathrm{~Hz}, 1 \mathrm{H}), 8.54$ $(\mathrm{d}, J=5.4 \mathrm{~Hz}, 1 \mathrm{H}), 8.24(\mathrm{ddd}, J=8.3,2.4,1.5 \mathrm{~Hz}, 1 \mathrm{H}), 8.18(\mathrm{dd}, J$ $=4.4,1.5 \mathrm{~Hz}, 1 \mathrm{H}), 7.45(\mathrm{~d}, J=5.4 \mathrm{~Hz}, 1 \mathrm{H}), 7.34(\mathrm{dd}, J=8.3,4.4$ $\mathrm{Hz}, 1 \mathrm{H}), 7.13(\mathrm{~d}, J=9.8 \mathrm{~Hz}, 1 \mathrm{H}), 5.53-5.58(\mathrm{~m}, 1 \mathrm{H}), 4.80(\mathrm{~d}, J=$ $2.4 \mathrm{~Hz}, 2 \mathrm{H}), 4.00(\mathrm{~s}, 3 \mathrm{H})$. LC-MS $(\mathrm{m} / z): 350.2[\mathrm{M}+\mathrm{H}]^{+}$

4-(2-Cyclopropyl-6-methoxypyrazolo[1,5-b]pyridazin-3-yl)$\mathrm{N}$-(pyridin-3-yl)pyrimidin-2-amine (23g). In a vial 7 n $(30 \mathrm{mg}, 99$ $\mu \mathrm{mol}$ ), cesium carbonate (97 mg, $298 \mu \mathrm{mol}$ ), 3-aminopyridine (19 $\mathrm{mg}, 199 \mu \mathrm{mol})$, palladium(II) acetate $(1.1 \mathrm{mg}, 5.0 \mu \mathrm{mol})$, and Xantphos $(5.8 \mathrm{mg}, 10.0 \mu \mathrm{mol})$ were stirred in anhydrous dioxane $(1.5$ $\mathrm{mL}$ ). The reaction mixture was sealed then evacuated and backfilled with $\mathrm{N}_{2}$ three times. The reaction mixture was then subjected to microwave irradiation at $160{ }^{\circ} \mathrm{C}$ for $1 \mathrm{~h}$. The reaction was filtered through Celite and washed with $\mathrm{MeOH}$, then evaporated to dryness. Reverse phase preparative HPLC purification was performed using $\mathrm{ACN} /$ water $5-95 \%$ with $0.1 \%$ formic acid, to provide the title compound as a yellow solid (7.4 mg, 21\%). ${ }^{1} \mathrm{H}$ NMR $(500 \mathrm{MHz}$, methanol- $\left.d_{4}\right) \delta$ ppm $8.90(\mathrm{~d}, J=2.9 \mathrm{~Hz}, 1 \mathrm{H}), 8.77(\mathrm{~d}, J=9.3 \mathrm{~Hz}, 1$ $\mathrm{H}), 8.49(\mathrm{~d}, J=5.4 \mathrm{~Hz}, 1 \mathrm{H}), 8.31(\mathrm{ddd}, J=8.3,2.9,1.5 \mathrm{~Hz}, 1 \mathrm{H})$, $8.17(\mathrm{dd}, J=4.9,1.5 \mathrm{~Hz}, 1 \mathrm{H}), 7.45(\mathrm{~d}, J=5.4 \mathrm{~Hz}, 1 \mathrm{H}), 7.39(\mathrm{dd}, J=$ 8.3, $4.9 \mathrm{~Hz}, 1 \mathrm{H}), 6.94(\mathrm{~d}, J=9.3 \mathrm{~Hz}, 1 \mathrm{H}), 4.04(\mathrm{~s}, 3 \mathrm{H}), 2.36-2.43$ $(\mathrm{m}, 1 \mathrm{H}), 1.11-1.17(\mathrm{~m}, 2 \mathrm{H}), 1.05-1.10(\mathrm{~m}, 2 \mathrm{H})$. LC-MS $(\mathrm{m} / \mathrm{z})$ : $360.2[\mathrm{M}+\mathrm{H}]^{+}$.

4-(2-Cyclopropyl-6-morpholinopyrazolo[1,5-b]pyridazin-3yl)- $\mathrm{N}$-(pyridin-3-yl)pyrimidin-2-amine (23h). In a vial 7 o $(30 \mathrm{mg}$, $84 \mu \mathrm{mol}$ ), cesium carbonate ( $82 \mathrm{mg}, 252 \mu \mathrm{mol})$, 3-aminopyridine (16 
mg, $168 \mu \mathrm{mol})$, palladium(II) acetate $(0.9 \mathrm{mg}, 4.2 \mu \mathrm{mol})$, and Xantphos $(5 \mathrm{mg}, 8.4 \mu \mathrm{mol})$ were stirred in anhydrous dioxane $(1.5$ $\mathrm{mL}$ ), and the reaction mixture was sealed then evacuated and backfilled with $\mathrm{N}_{2}$ three times. The reaction mixture was then subjected to microwave irradiation at $160{ }^{\circ} \mathrm{C}$ for $1 \mathrm{~h}$. The reaction was filtered through Celite and washed with EtOAc, then evaporated to dryness. Reverse phase preparative HPLC purification was performed using ACN/water 5-95\% with $0.1 \%$ formic acid, to afford the title compound as a pale-yellow solid $(11.0 \mathrm{mg}, 32 \%) .{ }^{1} \mathrm{H}$ NMR $\left(500 \mathrm{MHz}\right.$, methanol- $\left.d_{4}\right) \delta \mathrm{ppm} 8.91(\mathrm{~d}, J=2.9 \mathrm{~Hz}, 1 \mathrm{H}), 8.62(\mathrm{~d}, J=$ $9.8 \mathrm{~Hz}, 1 \mathrm{H}), 8.46(\mathrm{~d}, J=5.4 \mathrm{~Hz}, 1 \mathrm{H}), 8.29(\mathrm{ddd}, J=8.3,2.9,1.5 \mathrm{~Hz}$, $1 \mathrm{H}), 8.16(\mathrm{dd}, J=4.9,1.5 \mathrm{~Hz}, 1 \mathrm{H}), 7.43(\mathrm{~d}, J=5.4 \mathrm{~Hz}, 2 \mathrm{H}), 7.40$ $(\mathrm{dd}, J=8.3,4.9 \mathrm{~Hz}, 1 \mathrm{H}), 7.17(\mathrm{~d}, J=9.8 \mathrm{~Hz}, 1 \mathrm{H}), 3.83(\mathrm{t}, J=4.9$ $\mathrm{Hz}, 4 \mathrm{H}), 3.55(\mathrm{t}, J=4.9 \mathrm{~Hz}, 4 \mathrm{H}), 2.32-2.42(\mathrm{~m}, 1 \mathrm{H}), 1.10-1.15$ $(\mathrm{m}, 2 \mathrm{H}), 1.04-1.08(\mathrm{~m}, 2 \mathrm{H})$. LC-MS $(\mathrm{m} / z): 415.1[\mathrm{M}+\mathrm{H}]^{+}$.

4-(6-Morpholinopyrazolo[1,5-b]pyridazin-3-yl)- $\mathrm{N}$-(pyridin3-yl)pyrimidin-2-amine (23i). In a vial $7 \mathbf{b}(30 \mathrm{mg}, 95 \mu \mathrm{mol})$, cesium carbonate (93 mg, $284 \mu \mathrm{mol})$, 3-aminopyridine (18 mg, 189 $\mu \mathrm{mol})$, palladium(II) acetate $(1.1 \mathrm{mg}, 4.7 \mu \mathrm{mol})$, and Xantphos (5.5 $\mathrm{mg}, 9.5 \mu \mathrm{mol})$ were stirred in anhydrous dioxane $(1.5 \mathrm{~mL})$, and the reaction mixture was sealed then evacuated and backfilled with $\mathrm{N}_{2}$ three times. The reaction mixture was then subjected to microwave irradiation at $160{ }^{\circ} \mathrm{C}$ for $1 \mathrm{~h}$. The reaction was filtered through Celite and washed with EtOAc, then evaporated to dryness. Reverse phase preparative HPLC purification was performed using ACN/water 5$95 \%$ with $0.1 \%$ formic acid, affording the title compound as a white solid (7.2 mg, 20\%). ${ }^{1} \mathrm{H}$ NMR (500 MHz, methanol- $\left.d_{4}\right) \delta$ ppm 8.89$8.93(\mathrm{~m}, 1 \mathrm{H}), 8.79(\mathrm{~d}, J=9.8 \mathrm{~Hz}, 1 \mathrm{H}), 8.38-8.42(\mathrm{~m}, 2 \mathrm{H}), 8.26$ (ddd, $J=8.3,2.9,1.5 \mathrm{~Hz}, 1 \mathrm{H}), 8.15-8.21(\mathrm{~m}, 1 \mathrm{H}), 7.40(\mathrm{dd}, J=8.3$, $4.9 \mathrm{~Hz}, 1 \mathrm{H}), 7.24-7.29(\mathrm{~m}, 2 \mathrm{H}), 3.85(\mathrm{t}, J=4.9 \mathrm{~Hz}, 4 \mathrm{H}), 3.60(\mathrm{t}, J$ $=4.9 \mathrm{~Hz}, 4 \mathrm{H})$. LC-MS $(m / z): 375.1[\mathrm{M}+\mathrm{H}]^{+}$.

4-((4-(6-Morpholinopyrazolo[ $1,5-b]$ pyridazin-3-yl)pyrimidin-2-yl)amino)cyclohexan-1-ol (23j). In a vial 2-4b (20 $\mathrm{mg}, 63 \mu \mathrm{mol})$, and trans-4-amino-cyclohexanol $(36 \mathrm{mg}, 316 \mu \mathrm{mol})$ were stirred in $n$ - $\mathrm{BuOH}(2 \mathrm{~mL})$ and heated to $110{ }^{\circ} \mathrm{C}$ for $72 \mathrm{~h}$. Reaction mixture was then concentrated and column purification was undertaken using $\mathrm{MeOH} / \mathrm{DCM}, 2-5 \%$ to afford the title compound as a white solid (16.3 mg, 65.3\%). ${ }^{1} \mathrm{H}$ NMR $\left(500 \mathrm{MHz}\right.$, methanol- $\left.d_{4}\right)$ $\delta \mathrm{ppm} 8.82(\mathrm{~d}, J=9.8 \mathrm{~Hz}, 1 \mathrm{H}), 8.37(\mathrm{~s}, 1 \mathrm{H}), 8.18(\mathrm{~d}, J=5.4 \mathrm{~Hz}, 1$ $\mathrm{H}), 7.30(\mathrm{~d}, J=9.8 \mathrm{~Hz}, 1 \mathrm{H}), 6.99(\mathrm{~d}, J=5.4 \mathrm{~Hz}, 1 \mathrm{H}), 3.80-3.90$ (m, $5 \mathrm{H}), 3.56-3.68(\mathrm{~m}, 5 \mathrm{H}), 2.12-2.20(\mathrm{~m}, 2 \mathrm{H}), 2.01-2.09(\mathrm{~m}, 2$ H), 1.38-1.55 (m, 4 H). LC-MS $(m / z): 396.2[\mathrm{M}+\mathrm{H}]^{+}$.

4-((4-(6-Methoxypyrazolo[1,5-b]pyridazin-3-yl)pyrimidin-2yl)amino)cyclohexan-1-ol (23k). In a vial $7 \mathrm{c}(50 \mathrm{mg}, 191 \mu \mathrm{mol})$ and trans-4-aminocyclohexanol ( $44 \mathrm{mg}, 392 \mu \mathrm{mol})$ were stirred in $n$ $\mathrm{BuOH}(1.5 \mathrm{~mL})$ and subjected to microwave irradiation at $150{ }^{\circ} \mathrm{C}$ for $2.5 \mathrm{~h}$. The reaction was concentrated in vacuo then subjected to column purification $\mathrm{MeOH} / \mathrm{DCM} 0-5 \%$, to afford the title compound as a yellow solid (38.5 mg, 59\%). ${ }^{1} \mathrm{H}$ NMR $(500 \mathrm{MHz}$, methanol- $\left.d_{4}\right) \delta$ ppm 8.88-8.95 (m, $\left.1 \mathrm{H}\right), 8.42(\mathrm{~s}, 1 \mathrm{H}), 8.18(\mathrm{~d}, J=$ $5.4 \mathrm{~Hz}, 1 \mathrm{H}), 6.98-7.03(\mathrm{~m}, 2 \mathrm{H}), 4.07(\mathrm{~s}, 3 \mathrm{H}), 3.75-3.84(\mathrm{~m}, 1 \mathrm{H})$, $3.58-3.66(\mathrm{~m}, 1 \mathrm{H}), 2.08-2.17(\mathrm{~m}, 2 \mathrm{H}), 1.99-2.06(\mathrm{~m}, 2 \mathrm{H}), 1.35-$ $1.52(\mathrm{~m}, 4 \mathrm{H})$. LC-MS $(\mathrm{m} / \mathrm{z}): 341.2[\mathrm{M}+\mathrm{H}]^{+}$.

4-((4-(2-Cyclopropyl-6-methoxypyrazolo[1,5-b]pyridazin-3yl)pyrimidin-2-yl)amino)cyclohexan-1-ol (23I). In a vial $7 \mathbf{n}(30$ $\mathrm{mg}, 99 \mu \mathrm{mol})$ and trans-4-aminocyclohexanol $(23 \mathrm{mg}, 199 \mu \mathrm{mol})$ were stirred in $n-\mathrm{BuOH}(1.5 \mathrm{~mL})$ subjected to microwave irradiation at $150{ }^{\circ} \mathrm{C}$ for $2 \mathrm{~h}$. The reaction was concentrated in vacuo then subjected to column purification $\mathrm{MeOH} / \mathrm{DCM} 0-10 \%$, to afford the title compound as a white solid $(17.3 \mathrm{mg}, 66 \%$ based on recovered starting material). ${ }^{1} \mathrm{H}$ NMR $\left(500 \mathrm{MHz}\right.$, methanol- $\left.d_{4}\right) \delta \mathrm{ppm} 8.69-$ $8.76(\mathrm{~m}, 1 \mathrm{H}), 8.23(\mathrm{~d}, J=5.4 \mathrm{~Hz}, 1 \mathrm{H}), 7.16(\mathrm{~d}, J=5.4 \mathrm{~Hz}, 1 \mathrm{H})$, $6.92(\mathrm{~d}, J=9.3 \mathrm{~Hz}, 1 \mathrm{H}), 4.03(\mathrm{~s}, 3 \mathrm{H}), 3.75-3.85(\mathrm{~m}, 1 \mathrm{H}), 3.57-$ $3.65(\mathrm{~m}, 1 \mathrm{H}), 2.33-2.41(\mathrm{~m}, 1 \mathrm{H}), 2.07-2.16(\mathrm{~m}, 2 \mathrm{H}), 1.99-2.05$ (m, $2 \mathrm{H}), 1.36-1.48(\mathrm{~m}, 4 \mathrm{H}), 1.09-1.13(\mathrm{~m}, 2 \mathrm{H}), 1.04-1.07(\mathrm{~m}, 2$ H). LC-MS $(\mathrm{m} / z): 381.2[\mathrm{M}+\mathrm{H}]^{+}$.

4-((4-(2-(Hydroxymethyl)-6-methoxypyrazolo [1,5-b]pyridazin-3-yl)pyrimidin-2-yl)amino)cyclohexan-1-ol (23m). In a vial $71(50 \mathrm{mg}, 171 \mu \mathrm{mol})$ and trans-4-aminocyclohexanol $(39.5 \mathrm{mg}, 343 \mu \mathrm{mol})$ were stirred in $n-\mathrm{BuOH}(1.5 \mathrm{~mL})$ and subjected to microwave irradiation at $150{ }^{\circ} \mathrm{C}$ for $2 \mathrm{~h}$. The reaction was concentrated in vacuo then subjected to column purification EtOAc/ hex $25-100 \%$, to afford the title compound as a yellow solid $(33.2$ $\mathrm{mg}, 52 \%) .{ }^{1} \mathrm{H}$ NMR $\left(500 \mathrm{MHz}\right.$, methanol- $\left.d_{4}\right) \delta \mathrm{ppm} 8.70(\mathrm{~d}, J=9.8$ $\mathrm{Hz}, 1 \mathrm{H}), 8.26(\mathrm{~d}, J=5.4 \mathrm{~Hz}, 1 \mathrm{H}), 7.09(\mathrm{~d}, J=5.4 \mathrm{~Hz}, 1 \mathrm{H}), 7.00(\mathrm{~d}$, $J=9.8 \mathrm{~Hz}, 1 \mathrm{H}), 4.91(\mathrm{~s}, 2 \mathrm{H}), 4.06(\mathrm{~s}, 3 \mathrm{H}), 3.75-3.83(\mathrm{~m}, 1 \mathrm{H})$, 3.57-3.65 (m, $1 \mathrm{H}), 2.07-2.15(\mathrm{~m}, 2 \mathrm{H}), 2.00-2.03(\mathrm{~m}, 2 \mathrm{H}), 1.35-$ $1.50(\mathrm{~m}, 4 \mathrm{H})$. LC-MS $(\mathrm{m} / \mathrm{z}): 371.2[\mathrm{M}+\mathrm{H}]^{+}$.

2-Chloro-4-methyl-6-((trimethylsilyl)ethynyl)pyrimidine (24a). In a reaction vial 2,4-dichloro-6-methylpyrimidine ( $1 \mathrm{~g}, 6.1$ $\mathrm{mmol}), \mathrm{Pd}\left(\mathrm{PPh}_{3}\right)_{2} \mathrm{Cl}_{2}(86 \mathrm{mg}, 123 \mu \mathrm{mol})$, and $\mathrm{CuI}(35 \mathrm{mg}, 184$ $\mu \mathrm{mol})$ were added. A degassed solution of triethylamine $(2.6 \mathrm{~mL}, 18.4$ $\mathrm{mmol}$ ) and THF (12 mL) were added under $\mathrm{N}_{2}$ to the reaction vial, followed by ethynyltrimethylsilane $(961 \mu \mathrm{L}, 6.75 \mathrm{mmol})$. The reaction mixture was heated to $50{ }^{\circ} \mathrm{C}$ for $16 \mathrm{~h}$. Reaction mixture was then filtered through Celite and washed with EtOAc. The reaction mixture was concentrated in vacuo then subjected to column purification EtOAc/hexanes 0-10\%, to yield the desired product as an off-white solid ( $370 \mathrm{mg}, 27 \%) .{ }^{1} \mathrm{H}$ NMR ( $500 \mathrm{MHz}$, chloroform- $d$ ) $\delta$ ppm $7.16(\mathrm{~s}, 1 \mathrm{H}), 2.48(\mathrm{~s}, 3 \mathrm{H}), 0.24(\mathrm{~s}, 9 \mathrm{H})$. LC-MS $(\mathrm{m} / z)$ : $225.0\left({ }^{35} \mathrm{Cl}\right), 227.0\left({ }^{37} \mathrm{Cl}\right)[\mathrm{M}+\mathrm{H}]^{+}$

2-Chloro-4-ethynyl-6-methylpyrimidine (24b). In a vial 24a $(370 \mathrm{mg}, 1.65 \mathrm{mmol})$ was stirred in $\mathrm{MeOH}(10 \mathrm{~mL})$, and $\mathrm{KOH}(0.46$ $\mathrm{mg}, 8.2 \mu \mathrm{mol}$ ) was added. After $30 \mathrm{~min}$ the reaction was stopped and concentrated in vacuo, to yield the product as a pale-yellow solid (240 $\mathrm{mg}, 96 \%) .{ }^{1} \mathrm{H}$ NMR (500 MHz, chloroform- $d$ ) $\delta$ ppm $7.23(\mathrm{~s}, 1 \mathrm{H})$, $3.40(\mathrm{~s}, 1 \mathrm{H}), 2.55(\mathrm{~s}, 3 \mathrm{H})$. LC-MS $(\mathrm{m} / z): 152.7\left({ }^{35} \mathrm{Cl}\right), 154.7$ $\left({ }^{37} \mathrm{Cl}\right)[\mathrm{M}+\mathrm{H}]^{+}$

3-(2-Chloro-6-methylpyrimidin-4-yl)pyrazolo[ 1,5-b]pyridazine (25). (Aminooxy)sulfonic acid ( $889 \mathrm{mg}, 7.86 \mathrm{mmol}$ ) was dissolved in $7 \mathrm{~mL}$ of water, and to the clear solution was added saturated sodium bicarbonate until effervescence ceased $(\mathrm{pH} \sim 6)$. The clear colorless solution was heated to $70{ }^{\circ} \mathrm{C}$, and pyridazine $(378$ $\mu \mathrm{L}, 5.24 \mathrm{mmol}$ ) was added and the reaction mixture was stirred at 70 ${ }^{\circ} \mathrm{C}$ for $2 \mathrm{~h}$. The reaction was cooled to room temperature, neutralized with saturated sodium bicarbonate (until effervescence ceased) and then solution of $24 \mathrm{~b}(200 \mathrm{mg}, 1.31 \mathrm{mmol})$ in DCM $(20 \mathrm{~mL})$ was added followed by $\mathrm{KOH}(74 \mathrm{mg}, 1.3 \mathrm{mmol})$ and the reaction was stirred at room temperature for $16 \mathrm{~h}$. The reaction mixture was diluted with DCM and washed with water and brine then dried over sodium sulfate, filtered and evaporated to get the crude product which was purified by column chromatography using EtOAc/hex $30-50 \%$ to provide the desired compound as a pink solid (121 mg, 38\%). ${ }^{1} \mathrm{H}$ NMR $(500 \mathrm{MHz}$, chloroform- $d$ ) $\delta$ ppm $9.06(\mathrm{dd}, J=9.3,2.0 \mathrm{~Hz}, 1$ $\mathrm{H}), 8.53(\mathrm{~s}, 1 \mathrm{H}), 8.46(\mathrm{dd}, J=4.4,2.0 \mathrm{~Hz}, 1 \mathrm{H}), 7.40(\mathrm{~s}, 1 \mathrm{H}), 7.29$ $(\mathrm{dd}, J=9.3,4.4 \mathrm{~Hz}, 1 \mathrm{H}), 2.59(\mathrm{~s}, 3 \mathrm{H}) . \mathrm{LC}-\mathrm{MS}(\mathrm{m} / \mathrm{z}): 246.1\left({ }^{35} \mathrm{Cl}\right)$, $248.0\left({ }^{37} \mathrm{Cl}\right)[\mathrm{M}+\mathrm{H}]^{+}$.

2-Chloro-5-methyl-4-((trimethylsilyl)ethynyl)pyrimidine (26a). In a reaction vial 2,4-dichloro-5-methylpyrimidine (1 g, 6.1 $\mathrm{mmol}), \mathrm{Pd}\left(\mathrm{PPh}_{3}\right)_{2} \mathrm{Cl}_{2}(86 \mathrm{mg}, 123 \mu \mathrm{mol})$, and $\mathrm{CuI}(35 \mathrm{mg}, 184$ $\mu \mathrm{mol})$ were added. A degassed solution of triethylamine $(2.6 \mathrm{~mL}, 18.4$ $\mathrm{mmol}$ ) in THF $(12 \mathrm{~mL})$ was added under $\mathrm{N}_{2}$ to the reaction vial, followed by ethynyltrimethylsilane (961 $\mu \mathrm{L}, 6.75 \mathrm{mmol}$ ). The reaction mixture was heated to $50{ }^{\circ} \mathrm{C}$ for $16 \mathrm{~h}$. The reaction was then filtered through Celite and washed with EtOAc. The reaction mixture was concentrated in vacuo and subjected to column purification EtOAc/hexanes $0-10 \%$, to provide the compound as a white solid (713 mg, 52\%). ${ }^{1} \mathrm{H}$ NMR (500 MHz, chloroform- $d$ ) $\delta$ ppm $8.46(\mathrm{~s}, 1 \mathrm{H}), 2.36(\mathrm{~s}, 3 \mathrm{H}), 0.28(\mathrm{~s}, 9 \mathrm{H})$. LC-MS $(\mathrm{m} / \mathrm{z}): 225.0$ $\left.\left({ }^{35} \mathrm{Cl}\right), 227.0\left({ }^{37} \mathrm{Cl}\right)[\mathrm{M}+\mathrm{H}]\right]^{+}$.

2-Chloro-4-ethynyl-5-methylpyrimidine (26b). In a vial 26a $(713 \mathrm{mg}, 3.2 \mathrm{mmol})$ was stirred in $\mathrm{MeOH}(20 \mathrm{~mL})$, and $\mathrm{KOH}(0.9$ $\mathrm{mg}, 16 \mu \mathrm{mol})$ was added, and the reaction was stirred at room temperature. After $30 \mathrm{~min}$ the reaction was stopped and concentrated in vacuo, then subjected to column purification EtOAc/hex 10-25\% to obtain the desired compound as a white solid $(361 \mathrm{mg}, 75 \%) .{ }^{1} \mathrm{H}$ NMR $\left(500 \mathrm{MHz}, \mathrm{DMSO}-d_{6}\right) \delta$ ppm $8.74(\mathrm{~s}, 1 \mathrm{H}), 5.13(\mathrm{~s}, 1 \mathrm{H}), 2.31$ $(\mathrm{s}, 3 \mathrm{H})$. LC-MS $(\mathrm{m} / z): 152.8\left({ }^{35} \mathrm{Cl}\right), 154.7\left({ }^{37} \mathrm{Cl}\right)[\mathrm{M}+\mathrm{H}]^{+}$.

3-(2-Chloro-5-methylpyrimidin-4-yl)pyrazolo [1,5-b]pyridazine (27). (Aminooxy)sulfonic acid (889 mg, $7.86 \mathrm{mmol}$ ) was 
dissolved in $7 \mathrm{~mL}$ of water, and saturated sodium bicarbonate was added to the clear solution until effervescence ceased $(\mathrm{pH} \sim 6)$. The clear colorless solution was heated at $70{ }^{\circ} \mathrm{C}$, and pyridazine $(378 \mu \mathrm{L}$, $5.24 \mathrm{mmol}$ ) was added and the reaction mixture was stirred at $70^{\circ} \mathrm{C}$ for $2 \mathrm{~h}$. The reaction was then cooled to room temperature, neutralized with saturated sodium bicarbonate (until effervescence ceased) and then a solution of $26 \mathbf{b}(200 \mathrm{mg}, 1.31 \mathrm{mmol})$ in DCM (20 $\mathrm{mL})$ was added followed by $\mathrm{KOH}(148 \mathrm{mg}, 2.6 \mathrm{mmol})$ and the reaction was stirred at room temperature for $16 \mathrm{~h}$. The reaction mixture was diluted with DCM and washed with water and brine then dried over sodium sulfate, filtered and evaporated to get the crude product which was purified by column chromatography using $\mathrm{MeOH} / \mathrm{DCM} 0-2 \%$ to yield the desired compound as a brown solid (206 mg, 64\%). ${ }^{1} \mathrm{H}$ NMR (500 MHz, chloroform- $d$ ) $\delta$ ppm 9.13 $(\mathrm{dd}, J=9.3,2.0 \mathrm{~Hz}, 1 \mathrm{H}), 8.55(\mathrm{~s}, 1 \mathrm{H}), 8.50(\mathrm{dd}, J=4.4,2.0 \mathrm{~Hz}, 1$ $\mathrm{H}), 8.45(\mathrm{~s}, 1 \mathrm{H}), 7.32(\mathrm{dd}, J=9.3,4.4 \mathrm{~Hz}, 1 \mathrm{H}), 2.60(\mathrm{~s}, 3 \mathrm{H}) . \mathrm{LC}-$ MS $(\mathrm{m} / z): 246.1\left({ }^{35} \mathrm{Cl}\right), 248.0\left({ }^{37} \mathrm{Cl}\right)[\mathrm{M}+1]$.

2-(3-Chlorophenyl)-4,4,5,5-tetramethyl-1,3,2-dioxaborolane (28). In a vial 3-chloroiodobenzene $(52 \mu \mathrm{L}, 420 \mu \mathrm{mol})$, bis(pinacolato)diboron $(160 \mathrm{mg}, 629 \mu \mathrm{mol})$, potassium acetate (144 $\mathrm{mg}, 1.47 \mathrm{mmol})$, and $\mathrm{PdCl}_{2}(\mathrm{dppf}) \cdot \mathrm{CH}_{2} \mathrm{Cl}_{2}(17 \mathrm{mg}, 21 \mathrm{mmol})$ were combined, and the vial was sealed. Anhydrous dioxane $(3 \mathrm{~mL})$ was added and the reaction was evacuated and backfilled with $\mathrm{N}_{2}$ three times, then subjected to microwave irradiation at $160{ }^{\circ} \mathrm{C}$ for $30 \mathrm{~min}$. The reaction was cooled and filtered through Celite, concentrated in vacuo and taken forward without purification. LC-MS $(\mathrm{m} / \mathrm{z}): 156.7$ $\left({ }^{35} \mathrm{Cl}\right), 158.8\left({ }^{37} \mathrm{Cl}\right)[\mathrm{M}+\mathrm{H}]^{+}$(boronic acid).

3-(6-Chloropyridin-2-yl)pyrazolo[1,5-b]pyridazine (29). (Aminooxy)sulfonic acid (296 mg, $2.62 \mathrm{mmol}$ ) was dissolved in 2 $\mathrm{mL}$ of water, and to the clear solution was added saturated sodium bicarbonate until effervescence ceased $(\mathrm{pH} \sim 6)$. The clear colorless solution was heated to $70{ }^{\circ} \mathrm{C}$, then pyridazine $(126 \mu \mathrm{L}, 1.74 \mathrm{mmol})$ was added, and the reaction mixture was stirred at $70^{\circ} \mathrm{C}$ for $2 \mathrm{~h}$. The reaction mixture was then cooled to room temperature, neutralized with saturated sodium bicarbonate (until effervescence ceased) and then solution of 2-chloro-6-ethynylpyridine $(120 \mathrm{mg}, 872 \mu \mathrm{mol})$ in DCM $(10 \mathrm{~mL})$ was added followed by $\mathrm{KOH}(49 \mathrm{mg}, 872 \mu \mathrm{mol})$ and the reaction mixture was stirred at $40{ }^{\circ} \mathrm{C}$ for $72 \mathrm{~h}$, partial conversion to product was observed. Additional $\mathrm{KOH}(49 \mathrm{mg}, 872 \mu \mathrm{mol}$ ) was added and the reaction was stirred for another $24 \mathrm{~h}$ at $40{ }^{\circ} \mathrm{C}$. The reaction mixture was diluted with DCM and water and extracted. The organic layer was washed with brine then dried over sodium sulfate, filtered and evaporated to get the crude product which was purified by column chromatography using EtOAc/hex $25 \%$ to yield the product as a tan solid ( $18.5 \mathrm{mg}, 15 \%$ based on recovered starting material). ${ }^{1} \mathrm{H}$ NMR (400 MHz, chloroform- $d$ ) $\delta$ ppm 9.00 (dd, $J=8.8,2.2 \mathrm{~Hz}, 1$ H), $8.44(\mathrm{~s}, 1 \mathrm{H}), 8.38(\mathrm{dd}, J=4.4,2.2 \mathrm{~Hz}, 1 \mathrm{H}), 7.69(\mathrm{t}, J=8.1 \mathrm{~Hz}, 1$ $\mathrm{H}), 7.58(\mathrm{~d}, J=8.1 \mathrm{~Hz}, 1 \mathrm{H}), 7.13-7.22(\mathrm{~m}, 2 \mathrm{H})$. LC-MS $(\mathrm{m} / z)$ : $231.0\left({ }^{35} \mathrm{Cl}\right), 233.0\left({ }^{37} \mathrm{Cl}\right)[\mathrm{M}+\mathrm{H}]^{+}$.

3-(2-Chloropyridin-4-yl)pyrazolo[1,5-b]pyridazine (30). (Aminooxy)sulfonic acid (2.06 g, $18.2 \mathrm{mmol}$ ) was dissolved in 4 $\mathrm{mL}$ of water, and saturated sodium bicarbonate was added to the clear solution until effervescence ceased $(\mathrm{pH} \sim 6)$. The clear colorless solution was heated at $70{ }^{\circ} \mathrm{C}$, and pyridazine $(875 \mu \mathrm{L}, 12.1 \mathrm{mmol})$ was added. The reaction mixture heated at $70{ }^{\circ} \mathrm{C}$ for $2 \mathrm{~h}$, then cooled to room temperature, neutralized with saturated sodium bicarbonate (until effervescence ceased) and then a solution of 2-chloro-4ethynylpyridine $(417 \mathrm{mg}, 3.03 \mathrm{mmol})$ in DCM $(15 \mathrm{~mL})$ and $\mathrm{KOH}$ $(170 \mathrm{mg}, 3.0 \mathrm{mmol})$ was added then reaction mixture was stirred for $16 \mathrm{~h}$ at room temperature. The reaction mixture was diluted with DCM and washed with water and brine then dried over magnesium sulfate, filtered and evaporated to get the crude product which was purified by column chromatography using $\mathrm{MeOH} / \mathrm{DCM}$ 0-2\% followed by an additional column purification using EtOAc/hexanes $25-100 \%$ to afford the desired compound as a brown solid (173 mg, 25\%). ${ }^{1} \mathrm{H}$ NMR (500 MHz, chloroform- $d$ ) $\delta$ ppm $8.46(\mathrm{~d}, J=5.4 \mathrm{~Hz}$, $1 \mathrm{H}), 8.43(\mathrm{dd}, J=4.4,2.0 \mathrm{~Hz}, 1 \mathrm{H}), 8.36(\mathrm{~s}, 1 \mathrm{H}), 8.28(\mathrm{dd}, J=9.3$, $2.0 \mathrm{~Hz}, 1 \mathrm{H}), 7.53-7.56(\mathrm{~m}, 1 \mathrm{H}), 7.44(\mathrm{dd}, J=5.4,1.5 \mathrm{~Hz}, 1 \mathrm{H})$, $7.22(\mathrm{dd}, J=9.3,4.4 \mathrm{~Hz}, 1 \mathrm{H})$. LC-MS $(\mathrm{m} / z): 230.9\left({ }^{35} \mathrm{Cl}\right), 233.0$ $\left({ }^{37} \mathrm{Cl}\right)[\mathrm{M}+\mathrm{H}]^{+}$.

\section{ASSOCIATED CONTENT}

\section{Supporting Information}

The Supporting Information is available free of charge at https://pubs.acs.org/doi/10.1021/acs.jmedchem.9b01741.

Cidality assay results, additional compounds and associated biological data not presented in the manuscript, comparison of T. b. brucei $\mathrm{pEC}_{50}$ inhibition data to literature values for $\mathrm{GSK}-3 \beta \mathrm{pIC}_{50}, \mathrm{CDK}-2 \mathrm{pIC}_{50}$, and CDK-4 $\mathrm{pIC}_{50}$, additional $\mathrm{ADME}$ data (including mouse plasma stability, CYP450 inhibition and induction, Caco-2), kinase panel profiling of $\mathbf{2 0 g}$, blood and brain concentration of 20r as measured in the PK study, parasitemia levels measured during efficacy study, biological data of compound set against T. cruzi, $L$. donovani, S. mansoni, L6 and THP-1 cells, and HPLC traces of all compounds tested (PDF)

Molecular formula strings and some data (CSV)

\section{AUTHOR INFORMATION}

\section{Corresponding Author}

*E-mail: m.pollastri@neu.edu.

ORCID

Lori Ferrins: 0000-0001-8992-0919

Michael P. Pollastri: 0000-0001-9943-7197

Notes

The authors declare no competing financial interest.

${ }^{\perp}$ C.C.-O.: current e-mail, carlos.cordon-obras@pasteur.fr.

\section{ACKNOWLEDGMENTS}

This work was supported by National Institutes of Health Grants (R01AI114685 (M.P.P. and M.N.), R01AI082577 (M.P.P.), R56AI099476 (M.P.P.), R01AI124046 (M.P.P.), R21AI127594 (M.P.P.), the Spanish Ministerio de Economia, Industria y Competitividad (M.N., Grant SAF2015-71444-P; D.G.P., Grant SAF2016-79957-R., and Subdirección General de Redes y Centros de Investigación Cooperativa (RICET) (M.N., Grant RD16/0027/0019; D.G.P., Grant RD16/0027/ 0014), Grant RTI2018-097210-B-100 (MINCIU-FEDER) to F.G. C.R.C. acknowledges grant support from the NIH-NIAID (Grant R21AI126296) and the Bill and Melinda Gates Foundation (Grant OPP1171488), as well as the technical assistance of Brian M. Suzuki for screening adult S. mansoni. We are grateful to AstraZeneca for performing the in vitro ADME experiments presented throughout and to Charles River Labs for the in vitro ADME data presented in Tables S3S5 in the Supporting Information. We thank GSK Tres Cantos open lab foundation for running the PK studies discussed in this publication. An academic license for ChemAxon (https:// www.chemaxon.com) is gratefully acknowledged. We thank Dr. Melissa Buskes for help in the preparation of this manuscript.

\section{ABBREVIATIONS USED}

BBB, blood-brain barrier; NECT, nifurtimox-eflornithine combination therapy; iv, intravenous; HTS, high-throughput screen; CNS, central nervous system; MPO, multiparameter optimization; ADME, absorption, distribution, metabolism, and excretion; $\mathrm{RH}$, rat hepatocyte; $\mathrm{Cl}_{\text {int }}$ intrinsic clearance; HAT, human African trypanosomiasis; HLM, human liver microsome; GSK-3 $\beta$, glycogen synthase kinase $3 \beta$; CDK, cyclin dependent kinase; PPB, plasma protein binding; aq sol., 
thermodynamic aqueous solubility; HBD, hydrogen bond donor; SAR, structure-activity relationship; PK, pharmacokinetic; ip, intraperitoneal.

\section{REFERENCES}

(1) About Sleeping Sickness. https://www.dndi.org/diseasesprojects/hat/ (accessed Jan 25, 2018).

(2) Trypanosomiasis, human African (sleeping sickness). http:// www.who.int/mediacentre/factsheets/fs259/en/ (accessed Jan 25, 2018).

(3) Pollastri, M. P. Fexinidazole: A New Drug for African Sleeping Sickness on the Horizon. Trends Parasitol. 2018, 34 (3), 178-179.

(4) Brun, R.; Blum, J.; Chappuis, F.; Burri, C. Human African trypanosomiasis. Lancet 2010, 375 (9709), 148-159.

(5) Barrett, M. P.; Boykin, D. W.; Brun, R.; Tidwell, R. R. Human African trypanosomiasis: pharmacological re-engagement with a neglected disease. Br. J. Pharmacol. 2007, 152 (8), 1155-1171.

(6) Franco, J. R.; Simarro, P. P.; Diarra, A.; Ruiz-Postigo, J. A.; Samo, M.; Jannin, J. G. Monitoring the use of nifurtimox-eflornithine combination therapy (NECT) in the treatment of second stage gambiense human African trypanosomiasis. Res. Rep. Trop. Med. 2012, 3, 93-101.

(7) Priotto, G.; Kasparian, S.; Ngouama, D.; Ghorashian, S.; Arnold, U.; Ghabri, S.; Karunakara, U. Nifurtimox-eflornithine combination therapy for second-stage Trypanosoma brucei gambiense sleeping sickness: a randomized clinical trial in Congo. Clin. Infect. Dis. 2007, 45 (11), 1435-1442.

(8) Priotto, G.; Kasparian, S.; Mutombo, W.; Ngouama, D.; Ghorashian, S.; Arnold, U.; Ghabri, S.; Baudin, E.; Buard, V.; Kazadi-Kyanza, S.; Ilunga, M.; Mutangala, W.; Pohlig, G.; Schmid, C.; Karunakara, U.; Torreele, E.; Kande, V. Nifurtimox-eflornithine combination therapy for second-stage African Trypanosoma brucei gambiense trypanosomiasis: a multicentre, randomised, phase III, non-inferiority trial. Lancet 2009, 374 (9683), 56-64.

(9) Phase II/III studies show high efficacy and safety of fexinidazole, the first oral treatment for sleeping sickness. DNDi, 2017.

(10) Mesu, V. K. B. K.; Kalonji, W. M.; Bardonneau, C.; Mordt, O. V.; Blesson, S.; Simon, F.; Delhomme, S.; Bernhard, S.; Kuziena, W.; Lubaki, J.-P. F.; Vuvu, S. L.; Ngima, P. N.; Mbembo, H. M.; Ilunga, M.; Bonama, A. K.; Heradi, J. A.; Solomo, J. L. L.; Mandula, G.; Badibabi, L. K.; Dama, F. R.; Lukula, P. K.; Tete, D. N.; Lumbala, C.; Scherrer, B.; Strub-Wourgaft, N.; Tarral, A. Oral fexinidazole for latestage African Trypanosoma brucei gambiense trypanosomiasis: a pivotal multicentre, randomised, non-inferiority trial. Lancet 2018, 391 (10116), 144-154.

(11) European Medicines Agency recommends fexinidazole, the first all-oral treatment for sleeping sickness. https://www.dndi.org/2018/ media-centre/press-releases/ema-recommends-fexinidazole-first-alloral-treatment-sleeping-sickness/ (accessed Dec 5, 2018).

(12) Sokolova, A. Y.; Wyllie, S.; Patterson, S.; Oza, S. L.; Read, K. D.; Fairlamb, A. H. Cross-resistance to nitro drugs and implications for treatment of human African trypanosomiasis. Antimicrob. Agents Chemother. 2010, 54 (7), 2893-2900.

(13) Patterson, S.; Wyllie, S. Nitro drugs for the treatment of trypanosomatid diseases: past, present, and future prospects. Trends Parasitol. 2014, 30 (6), 289-298.

(14) Pivotal clinical trial to begin for first oral drug candidate specifically developed for sleeping sickness. https://www.dndi.org/ 2015/media-centre/press-releases/pr-scyx-7158/ (accessed Jan 31, 2018).

(15) Nwaka, S.; Ramirez, B.; Brun, R.; Maes, L.; Douglas, F.; Ridley, R. Advancing drug innovation for neglected diseases-criteria for lead progression. PLoS Neglected Trop. Dis. 2009, 3 (8), No. e440.

(16) Neglected Tropical Diseases. http://www.who.int/neglected diseases/diseases/en/ (accessed Jan 25, 2018).

(17) Klug, D. M.; Gelb, M. H.; Pollastri, M. P. Repurposing strategies for tropical disease drug discovery. Bioorg. Med. Chem. Lett. 2016, 26 (11), 2569-2576.
(18) Diaz, R.; Luengo-Arratta, S. A.; Seixas, J. D.; Amata, E.; Devine, W.; Cordon-Obras, C.; Rojas-Barros, D. I.; Jimenez, E.; Ortega, F.; Crouch, S.; Colmenarejo, G.; Fiandor, J. M.; Martin, J. J.; Berlanga, M.; Gonzalez, S.; Manzano, P.; Navarro, M.; Pollastri, M. P. Identification and characterization of hundreds of potent and selective inhibitors of Trypanosoma brucei growth from a kinase-targeted library screening campaign. PLoS Neglected Trop. Dis. 2014, 8 (10), No. e3253.

(19) Oduor, R. O.; Ojo, K. K.; Williams, G. P.; Bertelli, F.; Mills, J.; Maes, L.; Pryde, D. C.; Parkinson, T.; Van Voorhis, W. C.; Holler, T. P. Trypanosoma brucei glycogen synthase kinase-3, a target for antitrypanosomal drug development: a public-private partnership to identify novel leads. PLoS Neglected Trop. Dis. 2011, 5 (4), No. e1017.

(20) Ojo, K. K.; Gillespie, J. R.; Riechers, A. J.; Napuli, A. J.; Verlinde, C. L.; Buckner, F. S.; Gelb, M. H.; Domostoj, M. M.; Wells, S. J.; Scheer, A.; Wells, T. N.; Van Voorhis, W. C. Glycogen synthase kinase 3 is a potential drug target for African trypanosomiasis therapy. Antimicrob. Agents Chemother. 2008, 52 (10), 3710-3717.

(21) Naula, C.; Parsons, M.; Mottram, J. C. Protein kinases as drug targets in trypanosomes and Leishmania. Biochim. Biophys. Acta, Proteins Proteomics 2005, 1754 (1-2), 151-159.

(22) Parsons, M.; Worthey, E. A.; Ward, P. N.; Mottram, J. C. Comparative analysis of the kinomes of three pathogenic trypanosomatids: Leishmania major, Trypanosoma brucei and Trypanosoma cruzi. BMC Genomics 2005, 6, 127.

(23) Wager, T. T.; Hou, X.; Verhoest, P. R.; Villalobos, A. Moving beyond rules: the development of a central nervous system multiparameter optimization (CNS MPO) approach to enable alignment of druglike properties. ACS Chem. Neurosci. 2010, 1 (6), 435-449.

(24) Navarro, G.; Chokpaiboon, S.; De Muylder, G.; Bray, W. M.; Nisam, S. C.; McKerrow, J. H.; Pudhom, K.; Linington, R. G. Hit-tolead development of the chamigrane endoperoxide merulin A for the treatment of African sleeping sickness. PLoS One 2012, 7 (9), No. e46172.

(25) Target Product Profile - Sleeping Sickness. https://www.dndi. org/diseases-projects/hat/hat-target-product-profile/ (accessed Jun 20, 2019)

(26) Tavares, F. X.; Boucheron, J. A.; Dickerson, S. H.; Griffin, R. J.; Preugschat, F.; Thomson, S. A.; Wang, T. Y.; Zhou, H. N-Phenyl-4pyrazolo[1,5-b] pyridazin-3-ylpyrimidin-2-amines as Potent and Selective Inhibitors of Glycogen Synthase Kinase 3 with Good Cellular Efficacy. J. Med. Chem. 2004, 47 (19), 4716-4730.

(27) Xiao, J.; Guo, Z.; Guo, Y.; Chu, F.; Sun, P. Inhibitory mode of $\mathrm{N}$-phenyl-4-pyrazolo[1,5-b] pyridazin-3-ylpyrimidin-2-amine series derivatives against GSK-3: molecular docking and 3D-QSAR analyses. Protein Eng., Des. Sel. 2006, 19 (2), 47-54.

(28) Schaenzer, A. J.; Wlodarchak, N.; Drewry, D. H.; Zuercher, W. J.; Rose, W. E.; Ferrer, C. A.; Sauer, J. D.; Striker, R. GW779439X and Its Pyrazolopyridazine Derivatives Inhibit the Serine/Threonine Kinase Stk1 and Act As Antibiotic Adjuvants against beta-LactamResistant Staphylococcus aureus. ACS Infect. Dis. 2018, 4, 15081518.

(29) Urich, R.; Grimaldi, R.; Luksch, T.; Frearson, J. A.; Brenk, R.; Wyatt, P. G. The design and synthesis of potent and selective inhibitors of Trypanosoma brucei glycogen synthase kinase 3 for the treatment of human african trypanosomiasis. J. Med. Chem. 2014, 57 (18), 7536-7549.

(30) Woodland, A.; Grimaldi, R.; Luksch, T.; Cleghorn, L. A.; Ojo, K. K.; Van Voorhis, W. C.; Brenk, R.; Frearson, J. A.; Gilbert, I. H.; Wyatt, P. G. From on-target to off-target activity: identification and optimisation of Trypanosoma brucei GSK3 inhibitors and their characterisation as anti-Trypanosoma brucei drug discovery lead molecules. ChemMedChem 2013, 8 (7), 1127-1137.

(31) Stevens, K. L.; Reno, M. J.; Alberti, J. B.; Price, D. J.; KaneCarson, L. S.; Knick, V. B.; Shewchuk, L. M.; Hassell, A. M.; Veal, J. M.; Davis, S. T.; Griffin, R. J.; Peel, M. R. Synthesis and evaluation of pyrazolo[1,5-b]pyridazines as selective cyclin dependent kinase inhibitors. Bioorg. Med. Chem. Lett. 2008, 18 (21), 5758-5762. 
(32) Zhang, H. Q.; Xia, Z.; Vasudevan, A.; Djuric, S. W. Efficient Pdcatalyzed synthesis of 2-arylaminopyrimidines via microwave irradiation. Tetrahedron Lett. 2006, 47 (28), 4881-4884.

(33) Hagan, J. J.; Ratti, E.; Routledge, C. Use of Cyclooxygenase-2 Inhibitors for the Treatment of Depressive Disorders. Patent WO/ 2005/048999, 2005.

(34) Ishikawa, M.; Hashimoto, Y. Improvement in aqueous solubility in small molecule drug discovery programs by disruption of molecular planarity and symmetry. J. Med. Chem. 2011, 54 (6), $1539-1554$

(35) Bachovchin, K. A.; Sharma, A.; Bag, S.; Klug, D. M.; Schneider, K. M.; Singh, B.; Jalani, H. B.; Buskes, M. J.; Mehta, N.; Tanghe, S.; Momper, J. D.; Sciotti, R. J.; Rodriguez, A.; Mensa-Wilmot, K.; Pollastri, M. P.; Ferrins, L. Improvement of Aqueous Solubility of Lapatinib-Derived Analogues: Identification of a Quinolinimine Lead for Human African Trypanosomiasis Drug Development. J. Med. Chem. 2019, 62 (2), 665-687.

(36) Kaidanovich-Beilin, O.; Eldar-Finkelman, H. Long-term treatment with novel glycogen synthase kinase-3 inhibitor improves glucose homeostasis in ob/ob mice: molecular characterization in liver and muscle. J. Pharmacol. Exp. Ther. 2006, 316 (1), 17-24.

(37) Garcia-Hernandez, R.; Gomez-Perez, V.; Castanys, S.; Gamarro, F. Fitness of Leishmania donovani parasites resistant to drug combinations. PLoS Neglected Trop. Dis. 2015, 9 (4), No. e0003704.

(38) Long, T.; Rojo-Arreola, L.; Shi, D.; El-Sakkary, N.; Jarnagin, K.; Rock, F.; Meewan, M.; Rascon, A. A., Jr.; Lin, L.; Cunningham, K. A.; Lemieux, G. A.; Podust, L.; Abagyan, R.; Ashrafi, K.; McKerrow, J. H.; Caffrey, C. R. Phenotypic, chemical and functional characterization of cyclic nucleotide phosphodiesterase 4 (PDE4) as a potential anthelmintic drug target. PLoS Neglected Trop. Dis. 2017, 11 (7), No. e0005680.

(39) Probst, A.; Nguyen, T. N.; El-Sakkary, N.; Skinner, D.; Suzuki, B. M.; Buckner, F. S.; Gelb, M. H.; Caffrey, C. R.; Debnath, A. Bioactivity of Farnesyltransferase Inhibitors Against Entamoeba histolytica and Schistosoma mansoni. Front. Cell. Infect. Microbiol. 2019, 9 (180), 1-12.

(40) Abdulla, M. H.; Ruelas, D. S.; Wolff, B.; Snedecor, J.; Lim, K. C.; Xu, F.; Renslo, A. R.; Williams, J.; McKerrow, J. H.; Caffrey, C. R. Drug discovery for schistosomiasis: hit and lead compounds identified in a library of known drugs by medium-throughput phenotypic screening. PLoS Neglected Trop. Dis. 2009, 3 (7), No. e478.

(41) Gomez-Perez, V.; Manzano, J. I.; Garcia-Hernandez, R.; Castanys, S.; Campos Rosa, J. M.; Gamarro, F. 4-Amino bispyridinium derivatives as novel antileishmanial agents. Antimicrob. Agents Chemother. 2014, 58 (7), 4103-4112.

(42) Konsoula, R.; Jung, M. In vitro plasma stability, permeability and solubility of mercaptoacetamide histone deacetylase inhibitors. Int. J. Pharm. 2008, 361 (1-2), 19-25.

(43) Viswanadhan, V. N.; Ghose, A. K.; Revankar, G. R.; Robins, R. K. Atomic Physiochemical Parameters for Three Dimensional Structure Directed Structure-Activity Relationships. 4. Additional Parameters for Hydrophobic and Dispersive Interactions and Their Application for an Automated Superposition of Certain Naturally Occuring Nucleoside Antibiotics. J. Chem. Inf. Model. 1989, 29, 163172. 